Prepared for the U.S. Department of Energy

under Contract DE-AC05-76RL01830

\title{
Updated Conceptual Model for the 300 Area Uranium Groundwater Plume
}

\author{
JM Zachara \\ MD Freshley \\ GV Last \\ RE Peterson \\ BN Bjornstad
}

November 2012

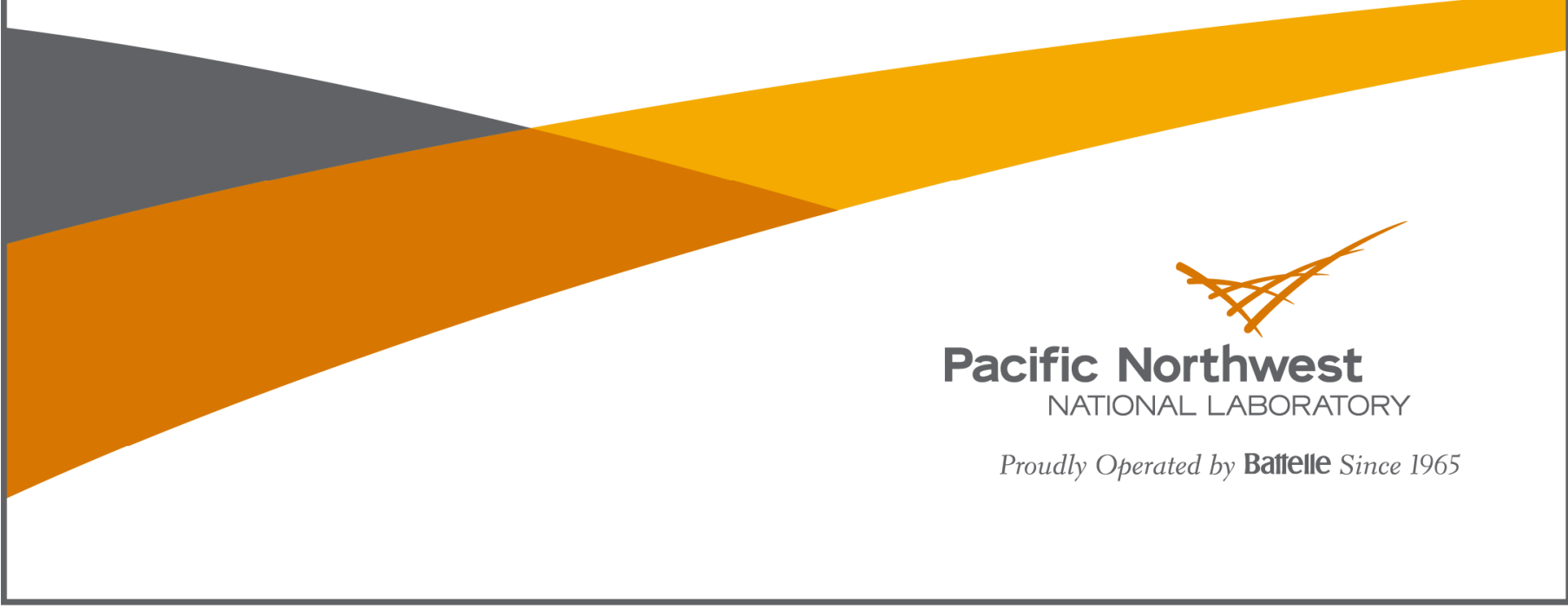




\title{
DISCLAIMER
}

This report was prepared as an account of work sponsored by an agency of the United States Government. Neither the United States Government nor any agency thereof, nor Battelle Memorial Institute, nor any of their employees, makes any warranty, express or implied, or assumes any legal liability or responsibility for the accuracy, completeness, or usefulness of any information, apparatus, product, or process disclosed, or represents that its use would not inf ringe privately owned rights. Reference herein to any specific commercial product, process, or service by trade name, trademark, manufacturer, or otherwise does not necessarily constitute or imply its endorsement, recommendation, or favoring by the United States Government or any agency thereof, or Battelle Memorial Institute. The views and opinions of authors expressed herein do not necessarily state or reflect those of the United States Government or any agency thereof.

\author{
PACIFIC NORTHWEST NATIONAL LABORATORY \\ operated by \\ BATTELLE \\ for the \\ UNITED STATES DEPARTMENT OF ENERGY \\ under Contract DE-AC05-76RL01830
}

Printed in the United States of America
Available to DOE and DOE contractors from the
Office of Scientific and Technical Information
P.O. Box 62, Oak Ridge, TN 37831-0062;
ph: (865) 576-8401
fax: $(865) 576-5728$
email: reports@adonis.osti.gov

Available to the public from the National Technical Information Service

5301 Shawnee Rd., Alexandria, VA 22312

ph: (800) 553-NTIS (6847)

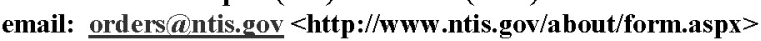

Online ordering: http://www.ntis.gov

This document was printed on recycled paper. 
PNNL-22048

RPT-DVZ-AFRI-007

\title{
Updated Conceptual Model for the 300 Area Uranium Groundwater Plume
}

\author{
JM Zachara \\ MD Freshley \\ GV Last \\ RE Peterson \\ BN Bjornstad
}

November 2012

Prepared for

the U.S. Department of Energy

under Contract DE-AC05-76RL01830

Pacific Northwest National Laboratory

Richland, Washington 99352 


\section{Summary}

The 300 Area uranium groundwater plume in the 300-FF-5 Operable Unit is residual from past discharge of nuclear fuel fabrication wastes to a number of liquid (and solid) disposal sites. The source zones in the disposal sites were remediated by excavation and backfilled to grade, but sorbed uranium remains in deeper, unexcavated vadose zone sediments. Despite source term removal, the groundwater plume has shown remarkable persistence, with concentrations exceeding the drinking water standard over an area of approximately $1 \mathrm{~km}^{2}$. The plume resides within a coupled vadose zone, groundwater, river zone system of immense complexity and scale. Interactions between geologic structure, the hydrologic system driven by the Columbia River, groundwater-river exchange points, and the geochemistry of uranium contribute to persistence of the plume.

The U.S. Department of Energy (DOE) recently completed a Remedial Investigation/Feasibility Study (RI/FS) to document characterization of the 300 Area uranium plume and plan for beginning to implement proposed remedial actions. As part of the RI/FS document, a conceptual model was developed that integrates knowledge of the hydrogeologic and geochemical properties of the 300 Area and controlling processes to yield an understanding of how the system behaves and the variables that control it. Recent results from the Hanford Integrated Field Research Challenge (IFRC) site and the Subsurface Biogeochemistry Scientific Focus Area Project funded by the DOE Office of Science were used to update the conceptual model and provide an assessment of key factors controlling plume persistence.

Hanford IFRC research identified several refinements to the conceptual model that can be extended to the 300 Area. Studies at the IFRC site with geophysics, hydraulic testing, and tracers confirm the presence of a lower permeability intermediate zone within the Hanford formation that has a large impact on the hydrologic system. Resulting vertical borehole flows have implications for monitoring, persistence of the uranium plume, and remediation approach. Research at the IFRC site has shown that uranium is mobilized in a heterogeneous way from the lower vadose zone in concentrations exceeding the drinking water standard during the spring high water table event, showing large fluctuations in concentrations over the approximate 3-month period of spring snowmelt. The observed behaviors of uranium strongly impact monitoring results, and should be considered in their interpretation. Improved persistence calculations should address more accurate adsorption-desorption parameters (e.g., surface complexation) for the saturated zone derived from fitting of new IFRC field experiment data. 


\section{Acronyms and Abbreviations}

BEU

CERCLA

cfs

DOE

DWS

EBF

EM

ERT

GPR

IFRC

MSL

PRZ

RCRA

$\mathrm{RI} / \mathrm{FS}$

SFA

$\mathrm{SpC}$ bicarbonate extractable uranium

Comprehensive Environmental Response, Compensation, and Liability Act

cubic feet per second

U.S. Department of Energy

drinking water standard

electronic borehole flowmeter

DOE Office of Environmental Management

electrical resistivity tomographic

ground-penetrating radar

Integrated Field Research Challenge

mean sea level

periodically rewetted zone

Resource Conservation and Recovery Act

Remedial Investigation/Feasibility Study

Scientific Focus Area

specific conductivity 


\section{Contents}

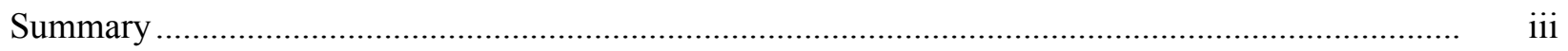

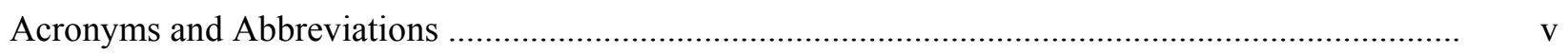

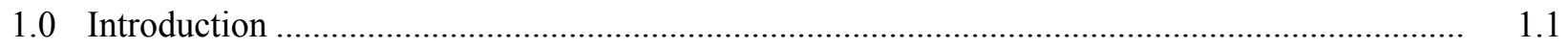

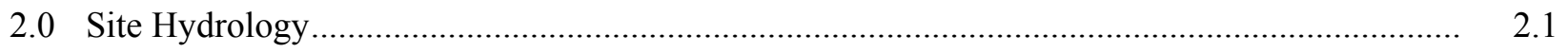

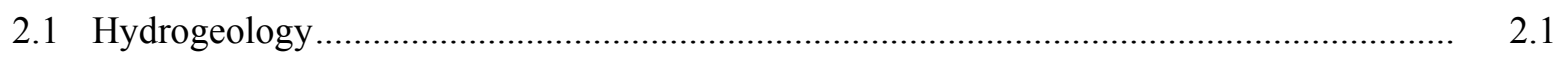

2.1.1 Columbia River Basalt Group .................................................................... 2.1

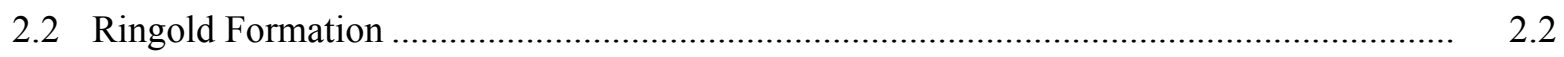

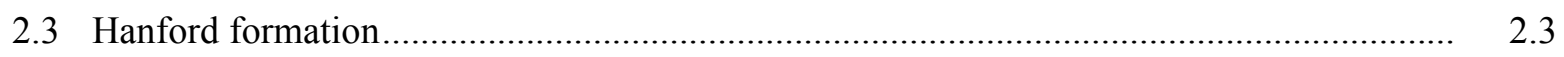

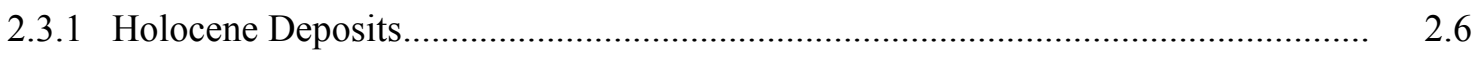

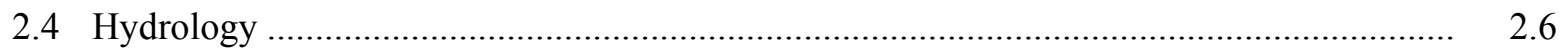

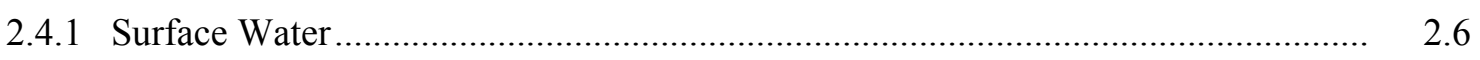

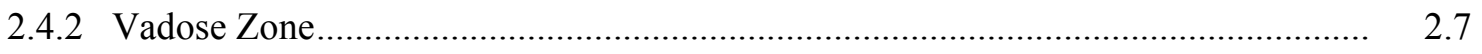

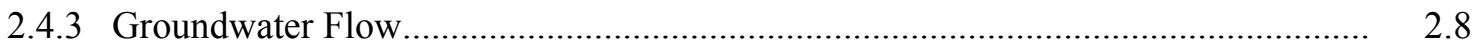

2.4.4 Hyporheic Zone and Discharge to the Columbia River ..................................... 2.10

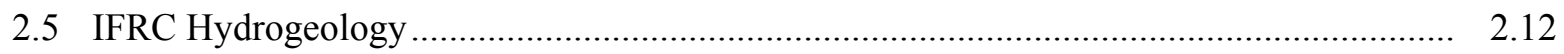

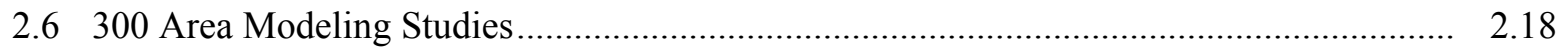

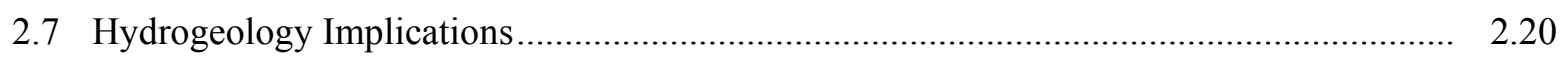

3.0 Trends in Monitoring Data and Uranium Plume Parameters ............................................... 3.1

3.1 Relationships to River and Groundwater Levels......................................................... 3.1

3.2 Uranium Concentration Trends Relative to Significant Events and Source Areas ............. 3.9

3.2.1 300 Area Process Trenches and 307 Process Trench ........................................... 3.9

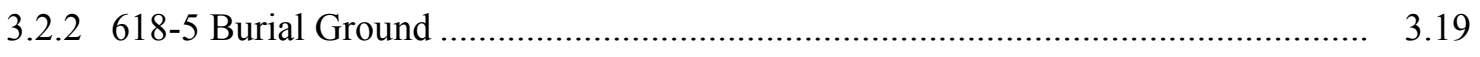

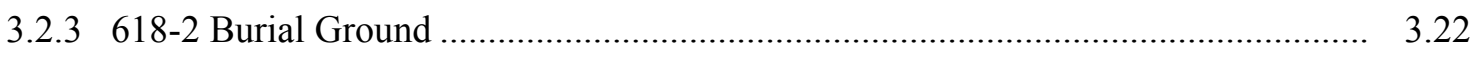

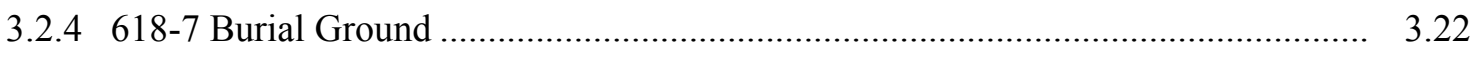

3.3 Trends in Uranium Plume Parameters..................................................................... 3.22

3.4 Groundwater Monitoring and Plume Parameter Implications......................................... 3.26

4.0 Mechanisms of Uranium Recharge to the Plume .............................................................

4.1 Comprehensive IFRC Monitoring Data from 2011 ...................................................... 4.1

4.2 Annual Variations in Vadose Zone Uranium Mobilization ............................................ 4.7

4.3 Implications of Uranium Plume Recharge ................................................................ 4.7

5.0 Geochemical Processes Controlling Plume Persistence ...................................................... 5.1

5.1 Laboratory Measurements of Adsorption and Desorption ................................................ 5.1

5.2 Advective Removal of Adsorbed Uranium .................................................................. 5.3

5.3 Field Measurements of In Situ Uranium Retardation..................................................... 5.5

5.4 Implications of Geochemical Processes ................................................................... 5.8 


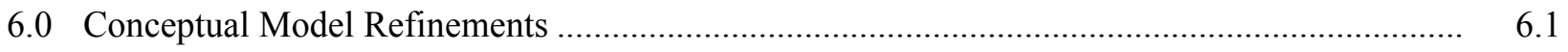

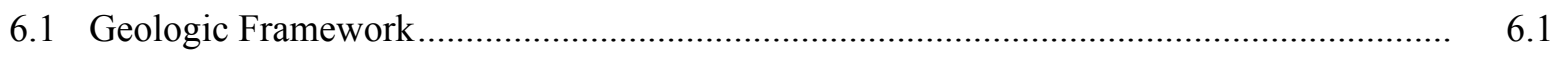

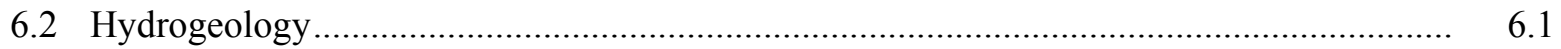

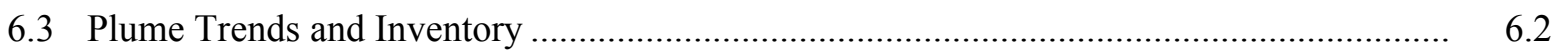

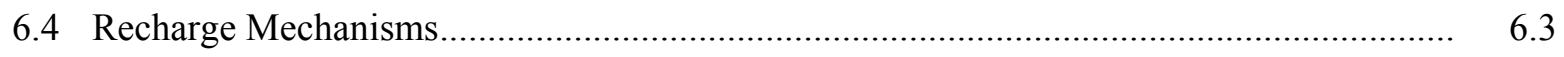

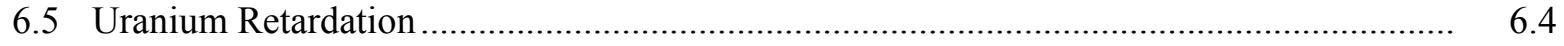

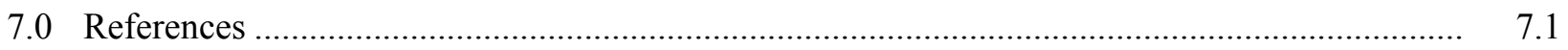




\section{Figures}

2.1 Eroded upper surface of the Ringold Formation showing locations of paleochannels based on the Hanford and Ringold contact identified from wellbores

2.2 Paleochannels in relation to interpreted groundwater-river exchange points identified by Slater et al. (2010).....

2.3 Priest Rapids Dam discharge hydrograph for selected years

2.4 Bulk conductivity prior to rain events in April 2012

2.5 Electrical resistivity tomographic-derived change in saturation after a series of significant rain events

2.6 Water table elevation contours for the 300 Area, March 2010 .

2.7 IFRC well locations

2.8 Results of the ERT inversion using known values.

2.9 Comparison of $\mathrm{K}$ estimated with borehole electromagnetic flowmeter and electrical conductivity extracted from the ERT inversion in the same wells

2.10 Interwell tracer-drift velocities relative to Columbia River stage

2.11 Gradient flow plot showing the computed trajectory of tracer injected in well 2-29 on April 2010

2.12 Bromide arrival in northwest multilevel well cluster.

3.1 Historic uranium and water table trends near the South and North Process Ponds

3.2 Map showing the potential inland extent of river-water intrusion, as indicated by specific conductance fluctuations at monitoring wells and the relationship to the top of the Ringold Formation

3.3 Relationship between uranium concentrations and water levels in well 399-1-17A, showing asymptotic decreases in concentrations following an influx of uranium..

3.4 Uranium concentration and water-level trends for well 399-1-7

3.5 Wells showing increased uranium concentrations when water level is raised.

3.6 Wells showing decreased uranium concentrations when water level is raised

3.7 Map illustrating areas where uranium concentrations vary in response to raised water levels at the well.

3.8 Time lag between highest water level at well 399-1-17A and highest subsequent uranium concentration in groundwater

3.9 Maximum uranium concentrations in groundwater during April-June 1996

3.10 Maximum uranium concentrations in groundwater during July-September 1997.

3.11 Maximum uranium concentrations in groundwater during July-September 1999

3.12 Maximum uranium concentrations in groundwater during July-September 2001

3.13 Maximum uranium concentrations in groundwater during April-June 2006

3.14 Relationship between river discharge, river stage, and groundwater levels at wells 399-1-10A and 399-1-17A

3.15 Maximum uranium concentrations in groundwater from April to June 2011 
3.17 Uranium concentrations in monitoring well 399-1-10A downgradient of the 300 Area Process Trenches and the 618-5 Burial Ground...

3.18 Maximum uranium concentrations in groundwater from December 2002-March 2003

3.19 Maximum uranium concentrations in groundwater from April-June 2003

3.20 Maximum uranium concentrations in groundwater from December 2007-March 2008.

3.21 Uranium concentrations in well 399-8-5A downgradient from the 618-7 Burial Ground.

3.22 Water level and uranium concentration trends in well 399-8-1

3.23 Maximum uranium concentrations in groundwater from December 2011 to March 2012.........

3.24 Estimated area, volume, and mass of the 300 Area uranium plume, 2002 to 2012

4.1 Uranium concentration, water table elevation, and specific conductivity data for IFRC well 399-3-30 during 2011

4.2 Uranium concentration, water table elevation, and specific conductivity data for IFRC well 399-2-26 during 2011

4.3 Chloride concentrations in waters from the three IFRC multiple-depth clusters during spring 2011

4.4 Uranium concentrations in waters from the three IFRC multiple-depth clusters during spring 2011

4.5. Uranium concentration, water table elevation, and specific conductivity data for IFRC well 399-3-30 during 2010.

4.6. Uranium concentrations, water table elevation, and specific conductivity data for IFRC well 399-2-26 during 2010

5.1. Column leaching of contaminant uranium from the $<7-\mathrm{mm}$ size fraction of a composite smear zone sediment from the Hanford IFRC site that was sampled in 2009

5.2. Field results for a high uranium injection experiment performed at the Hanford IFRC site in October 2011.

5.3. Field results for a high uranium injection experiment performed at the Hanford IFRC site in October 2011.

5.4. Field results for a high uranium injection experiment performed at the Hanford IFRC site in October 2011.

\section{Table}

3.1 Estimated parameters for 300 Area uranium plume, 2002 to 2012 


\subsection{Introduction}

The 300 Area uranium groundwater plume in 300-FF-5 Operable Unit is a well-studied contaminated site at the southern end of the Hanford Site in Washington State. The plume results from the historic discharge of nuclear fuel fabrication wastes to a number of liquid (and solid) waste sites, including two infiltration ponds and a disposal trench over the period from 1943 to 1971, and their infiltration and reactive transport through the vadose and saturated zones. To prevent further groundwater contamination, highly contaminated surface sediments were excavated from the primary liquid disposal sites in the 1990s to an approximate depth of $5 \mathrm{~m}$ based on specified cleanup standards at the time and disposed elsewhere. The excavations were subsequently backfilled to grade. Residual sorbed uranium exists in deeper, unexcavated vadose zone sediments below the historic disposal facilities, and as a disseminated sorbate in the lower vadose zone as a result of past high-water events. In spite of partial source term removal, the groundwater plume has shown remarkable persistence with concentrations exceeding regulatory standards over an area of approximately $1 \mathrm{~km}^{2}$ (Peterson et al. 2008b). Currently, the groundwater plume discharges waters with uranium concentrations above the drinking water standard (DWS) to the Columbia River approximately $3 \mathrm{~km}$ north of the water supply intake for the City of Richland, Washington. A remediation approach is sought that would restore the aquifer to the DWS and reduce uranium fluxes to the Columbia River.

An active groundwater monitoring network has existed in the 300 Area for close to 40 years, tracking temporal trends in groundwater uranium concentrations as required for environmental compliance (Peterson et al. 2008b). The plume has persisted well beyond expectations developed during the early stages of a remedial investigation under the Comprehensive Environmental Response, Compensation, and Liability Act (CERCLA), which began in the early 1990s. Beyond this, considerable characterization and research has been performed on the 300 Area uranium plume and its proximate environment by multiple DOE offices, including the Office of Environmental Management (EM) and the Office of Science over the last 20 years, making the plume one of Hanford's most studied contaminated soil and groundwater sites and one of the most important and comprehensive scientific case studies of uranium environmental geochemistry and reactive transport described in the peer-reviewed literature. More than 35 highly visible publications from the DOE National Laboratory and university community have been published in the past 20 years. Collectively, these studies have yielded considerable information that has been assimilated and interpreted by Zachara et al. (2007), Peterson et al. (2008), DOE-RL (2011), this report, and others.

Research objectives for the EM and Office of Science efforts have been multiple, including the following: 1) defining hydrogeologic properties of the aquifer and the remaining inventory of contaminant uranium; 2) understanding and quantifying coupled geochemical and hydrologic processes controlling groundwater uranium concentrations and their temporal dynamics; 3) developing and parameterizing reactive transport models that simulate and predict uranium groundwater concentrations; and 4) identifying and testing a suitable and effective remedial strategy.

The uranium plume resides within a coupled vadose zone - a groundwater and river system of immense complexity and scale. The plume resides within the groundwater-river interaction zone that experiences hourly, daily, and seasonal dynamics driven by the hydrologic cycle of the Columbia River.

The interactive effects of varied geologic structure, dynamic hydrology over multiple time-scales, and the complex geochemistry of uranium have been major impediments to understanding and modeling this 
complex system, and developing a suitable remedial strategy. Although it has existed for decades, in many ways, the 300 Area plume displays the characteristic of emergence, where its behaviors are not readily predicted from measurements of smaller-scale properties and processes.

The recent Remedial Investigation/Feasibility Study (RI/FS) and Proposed Plan report (DOE-RL 2010) summarizes the history of the 300 Area disposal and environmental monitoring operations, and the efforts that have been expended to date to bring the site into regulatory compliance. The report also summarizes considerable information on the geology, hydrology, and geochemistry of the 300 Area vadose zone and upper unconfined aquifer, and presents a conceptual hydrochemical model for the uranium plume. The conceptual model integrates knowledge on 1) the geologic, physical, hydrologic, and chemical properties of the system; and 2) operative and interactive hydrologic and geochemical processes to yield an understanding of how the system behaves and the variables that control it. The conceptual model provides an essential scientific framework for the development of numerical models to simulate the system, and functions as a critical tool for evaluating the feasibility of proposed remedial options.

Given the complexity of the 300 Area groundwater system and the uncertainty in the potential effectiveness of the proposed remedy for the 300 Area plume, it is essential that the conceptual model be comprehensive and inclusive of all relevant knowledge. Important recent results have become available from the Hanford Integrated Field Research Challenge (IFRC) site and the Subsurface Biogeochemistry Scientific Focus Area (SFA) Project funded by the DOE Office of Science. The new information includes updates on site hydrology, plume dynamics and inventory, recharge mechanisms of uranium to the plume, and geochemistry controlling persistence. Consequently, the objectives of this report are to 1) update the conceptual model to be inclusive of these important new field, laboratory, and interpretive findings; 2) provide a robust assessment of key factors controlling plume persistence; and 3) identify remaining uncertainties in the conceptual model that challenge decision making. 


\subsection{Site Hydrology}

The hydrogeology, groundwater-river interactions, and groundwater flow in the 300 Area are critical components of the conceptual model, contributing to the persistence of the uranium plume in the aquifer. The interactive effects of geologic structure, hydrogeologic properties, and seasonal dynamics driven by variations of Columbia River stage have added to the complexity of the conceptual model.

The 300 Area has been characterized over the operational period from 1943 to present. More recently, a drilling campaign was completed, focused on generating additional characterization data to support the RI/FS, and is documented in DOE-RL (2010). Research at the DOE Office of Science Hanford IFRC site included characterization and scientific studies within the footprint of the South Process Pond using a 60-m triangular area with more than 35 wells. Hydrogeologic characterization and field experiments at the IFRC yielded information regarding the complexity of the hydrogeologic system that previously did not exist. The updated information includes characterization of heterogeneities observed in the Hanford formation, including the 1) presence and importance of an intermediate lower permeability zone that impacts groundwater flow, monitoring well observations, and tracer behavior; 2) characterization with geophysics including vadose zone monitoring of infiltration, and a summary of modeling efforts. IFRC characterization and its relationship to the broader 300 Area hydrogeology is also described.

\subsection{Hydrogeology}

\subsubsection{Columbia River Basalt Group}

Miocene-age volcanic lava flows of the Columbia River Basalt Group underlie most of eastern Washington State, including the Hanford Site and the 300 Area. The uppermost unit beneath the 300 Area is the Ice Harbor member of the Saddle Mountains Basalt (DOE 1988). Confined aquifers within the Saddle Mountains Basalt and sedimentary interbeds of the Ellensburg Formation show small to moderate seasonal variations in hydraulic head (DOE 1988), indicating they are hydraulically separated from overlying aquifers. Other tests confirmed lateral groundwater flow in basalt interflow zones greatly exceeds vertical movement through dense basalt interiors (DOE 1988). Fractured, jointed, brecciated, and vesicular basalt that occur at the upper and/or lower surfaces of individual basalt flows, form permeable zones for groundwater flow in the confined basalt aquifers (Tolan et al. 2009; Lindsey et al. 2009; Porcello et al. 2009). The available data on hydraulic properties of the basalt flows indicate a large variability in local flow characteristics and show that groundwater flow occurs predominantly within the relatively thin interflow zones. Sand and gravel interbeds belonging to the Ellensburg Formation are locally present between basalt flows and contribute to groundwater flow. The dense basalt flow interiors and compacted silt and clay interbeds create effective barriers to vertical groundwater flow.

The 300 Area is located just northeast of the structural axis of the Pasco Syncline, which roughly parallels the present path of the Columbia River. This area is considered to be the discharge point for groundwater in the upper confined aquifers within the Columbia River Basalt Group in the Pasco Basin (Myers and Price 1979; Gephart et al. 1979) into the overlying unconfined sedimentary aquifer. However, discharges from the basalt aquifers to the unconfined aquifer in the 300 Area may be diverted 
by a continuous layer of Ringold Formation lower mud. The confined aquifers in the Columbia River Basalt Group do not significantly impact groundwater flow in the 300 Area unconfined aquifer.

\subsection{Ringold Formation}

The Ringold Formation was deposited on top of the basalt by the ancestral Columbia River. Lindsey (1995) defined three informal members of the Ringold Formation (Wooded Island, Taylor Flat, and Savage Island) based on dominant sediment types within the Pasco Basin. Only the lowermost member, Wooded Island, exists beneath the 300 Area (Williams et al. 2007, 2008). The Taylor Flat and Savage Island members, exposed in the White Bluffs across from the 300 Area, were eroded by the Columbia River during post-Ringold erosion due to uplift of the basalts and overlying sediments and Ice Age flooding since the late Pliocene era.

The Ringold Formation at the 300 Area is characterized by gravel-dominated units separated by mud-dominated overbank and lacustrine deposits (Williams et al. 2008). The lowermost portion of the Ringold Formation is composed of sand and/or gravel overlying basalt bedrock (Lindsey 1995; Schalla et al. 1988). Schalla et al. (1988) describes well-consolidated clayey sand to gravelly sand with clay that is discontinuous beneath the 300 Area and locally forms part of the uppermost confined aquifer. Re-examination of drilling and geophysical logs, however, supports the presence of this unit at only a few scattered locations. Therefore, it appears this unit is absent beneath most of the 300 Area.

At least three fine-grained, fluvial-overbank, and lacustrine intervals of the Ringold Formation are present in the vicinity of 300 Area. The upper two layers appear to be discontinuous and only the lower mud layer underlies the entire 300 Area. The top of the Ringold lower mud unit is generally considered to be the base of the unconfined aquifer system (Williams et al. 2008). The fine-grained sediments of the lower mud unit are compact and cohesive, of low-permeability, massive to weakly laminated, and varying in grain size, including clay, silt, and fine sand. The lower mud is thickest to the southwest of the 300 Area (up to $24 \mathrm{~m}$ ) and generally thins to the north. The upper surface of the lower mud unit generally rises to the northeast (Swanson 1992), consistent with the structural dip atop the northeast flank of the Pasco Syncline. A lack of vertical gradient between the Goose Island flow top (monitored by well 399-1-18C) and the overlying coarse-grained Ringold Unit E/C (monitored by well 399-1-18B) indicates some hydraulic communication may exist between the upper portion of the Ringold lower mud unit and the overlying higher permeability Ringold Unit E/C. Two other fine-grained intervals of the Ringold Formation also exist in the 300 Area. These represent fluvial-overbank facies associated with a meandering ancestral Columbia River. The upper interval, also known as the "undesignated fine-grained subunit" (Williams et al. 2007; Bjornstad et al. 2009), is present in the central 300 Area and the IFRC site where it is over $10 \mathrm{~m}$ (30 ft) thick. However, it is missing in the northern and southern portions of the 300 Area. This unit is believed to outcrop in the Columbia River channel along the 300 Area. All of the fine-grained units are characterized by relatively low hydraulic conductivities (Bjornstad et al. 2009).

Above the Ringold Formation lower mud are the combined Ringold Units B and C/E sand and gravel, which are indistinguishable except where intervening fine-grained intervals are present. This sedimentary facies was deposited within a high-energy, shallow, braided stream environment (Lindsay 1995). Gravel-dominated sediments of the Ringold Formation are up to $20 \mathrm{~m}(80 \mathrm{ft})$ thick, belonging mostly to Ringold Unit E. Cemented gravels observed in camera surveys in the Columbia River are also interpreted to be Ringold Unit E (Fritz et al. 2007). Some of Unit E may be equivalent to Ringold Units B and C 
(DOE-RL 2010). Ringold Unit $\mathrm{E}$ is a conglomeratic unit consisting of well-rounded and clast-supported pebbles and cobbles compacted within a matrix of fine- to medium-grained sand (Bjornstad et al. 2009; DOE-RL 2010). Varying amounts of silt or clay may occur within the matrix, primarily due to secondary alteration. Individual pebbles and cobble-size clasts, especially those composed of basalt, often display clay skins and weathering rinds, consistent with long contact times with groundwater. The hydraulic conductivities for the coarse-grained Ringold Unit E/C range from 36 to $51 \mathrm{~m} / \mathrm{d}$ (Williams et al. 2008). Depth-discrete zones tested during drilling averaged $8 \mathrm{~m} / \mathrm{d}$ and ranged from 0.7 to $39 \mathrm{~m} / \mathrm{d}$.

The top of the Ringold Formation in the 300 Area exhibits considerable relief. This is due to erosional scouring during cataclysmic Ice Age flooding (Bjornstad et al. 2009). The erosional unconformity separating the Ringold and Hanford formations represents a time gap of several million years. The top of the Ringold Formation either consists of fine-grained strata (uppermost of the three fine-grained intervals) or the gravel-dominated Unit $\mathrm{E} / \mathrm{C}$. The fine-grained unit is present at the top of the Ringold Formation in the central 300 Area, while the gravel-dominated unit is present in the northern and southern portions.

The principal direction of flow during the Ice Age flooding in the vicinity of the 300 Area was from the north-northwest. This is reflected in a braided channel network preserved at the surface from the last Ice Age floods (DOE-RL 2010). These flows scoured the top of the Ringold Formation, based on the orientation of paleochannels shown in Figure 2.1 (right). The flood-scoured Ringold Formation surface was later backfilled with extremely coarse-grained deposits of the Hanford formation during a series of subsequent flood events. The number of discrete, high-frequency, late-Pleistocene cataclysmic floods is estimated to have been 80 to 100 events, each separated by perhaps only few dozen of years (Waitt et al. 2009). There are at least two primary channels and two secondary, spillover channels through the 300 Area that were eroded during Ice Age flooding (Figure 2.1). A buried, north-to-northwest oriented ridge of the Ringold Formation separates the two primary channels that trend roughly parallel to the west bank of the present Columbia River. At least one spillover channel breached the now-buried Ringold ridge, linking the two primary channels between the former South and North Process Ponds. The breach is responsible for concentrating a significant amount of today's groundwater flow.

The paleochannels appear to extend eastward into the Columbia River associated with an increased thickness of saturated Hanford formation sediments near one of the river-bank springs (Spring 9). This has been documented in several separate studies (Fritz et al. 2007; Slater et al. 2010). Both of these studies support groundwater discharge into the river via a paleochannel filled with high-permeability Hanford formation west of Spring 9 (Figure 2.2).

\subsection{Hanford formation}

The gravel-dominated sediment of the informally defined Hanford formation forms the remainder of the vadose zone and upper portion of the unconfined aquifer (DOE-RL 2010). It consists of dominantly clast-supported pebble- to boulder-sized gravel deposited during repeated cataclysmic Ice Age (Missoula) floods (Bjornstad et al. 2009). The Hanford formation is highly heterogeneous, both vertically and laterally. Little or no correlation of sediment facies was observed in four pits excavated to the water table beneath the North and South Process Ponds (Bjornstad 2004) or between 35 closely spaced wells at the IFRC site (Bjornstad et al. 2009). Previous studies identified the presence of many randomly distributed, rounded, and cohesive rip-up clasts of the Ringold Formation eroded from the White Bluffs 
across the river from the 300 Area (Bjornstad et al. 2009). Evidence of these rip-up clasts has been found during drilling and characterization activities.
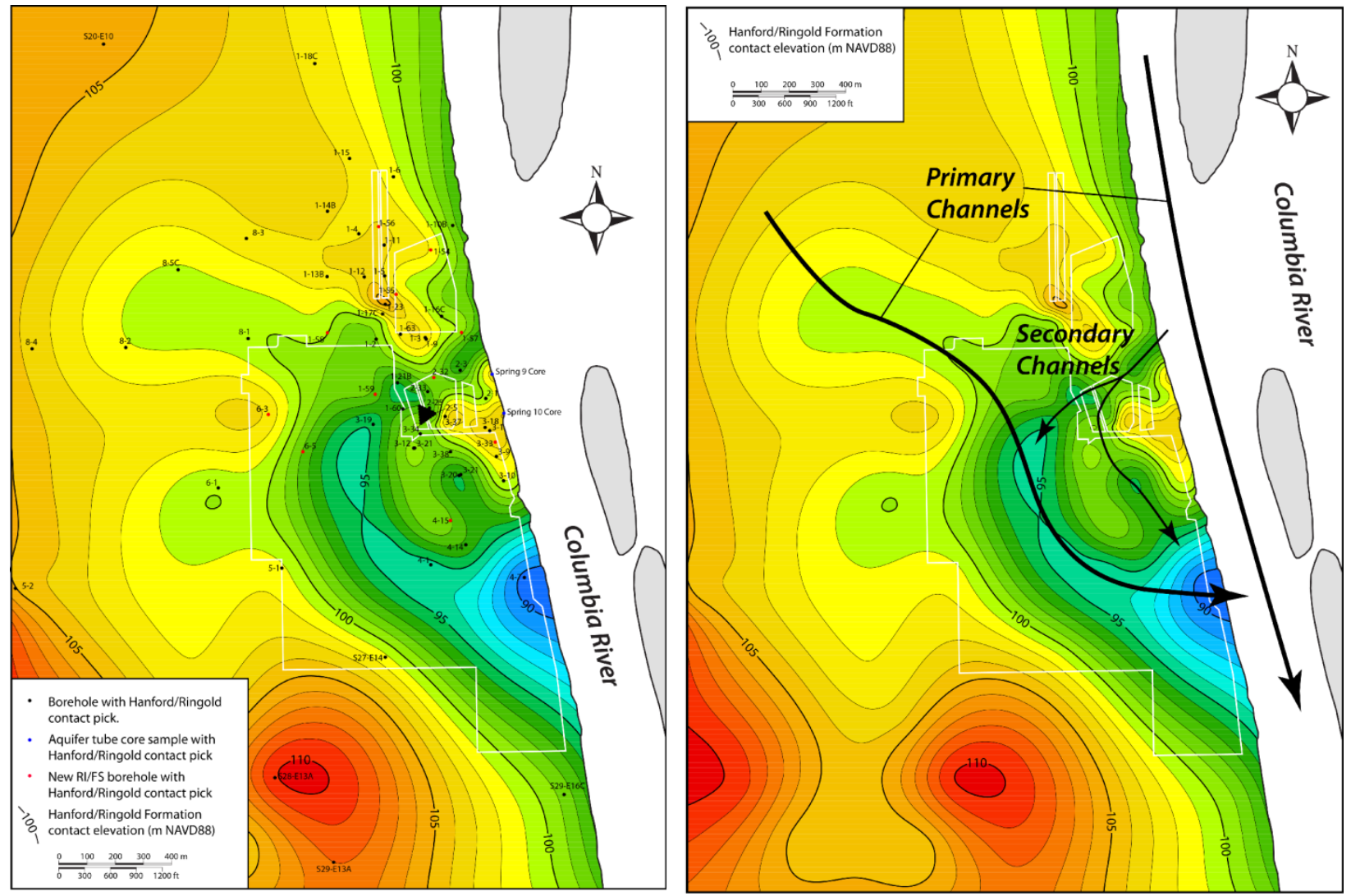

Figure 2.1. Eroded upper surface of the Ringold Formation showing locations of paleochannels (right panel) based on the Hanford and Ringold contact identified from wellbores (left panel)

The sediments of the Hanford formation are highly heterogeneous and chaotic mixtures of gravel, sand, and silt, consistent with rapid erosion and deposition by cataclysmic floods. The dominant sediment facies is clast-supported, pebble- to boulder-size gravel composed mostly of subangular basalt. A wide range of materials fills the matrices between gravel clasts, including loose gray (i.e., basalt) sand, a sand-silt mixture, and cohesive brown silt with clay. In some samples, matrix material is missing, producing an open-framework fabric. The saturated portion of the Hanford formation ranges from 3 to $4 \mathrm{~m}$ at the IFRC site and exhibits very high permeability compared with the underlying Ringold Formation; its hydraulic conductivity is measured in many hundreds to thousands of meters per day. Hydraulic conductivities determined during aquifer testing in wells range from 980 to $>5000 \mathrm{~m} / \mathrm{d}$ (Schalla et al. 1988; Swanson 1992; Lindberg and Bond 1979; Williams et al. 2008). Depth-discrete aquifer testing performed during drilling within the Hanford formation ranged from $>100$ to $2200 \mathrm{~m} / \mathrm{d}$ (Williams et al. 2007). Fritz et al. (2007) reported that hydraulic conductivities of the Hanford formation in the hyporheic zone were less, ranging from 0.4 to $170 \mathrm{~m} / \mathrm{d}$, measured from 0 - to $4-\mathrm{m}$ depths in aquifer tubes. 


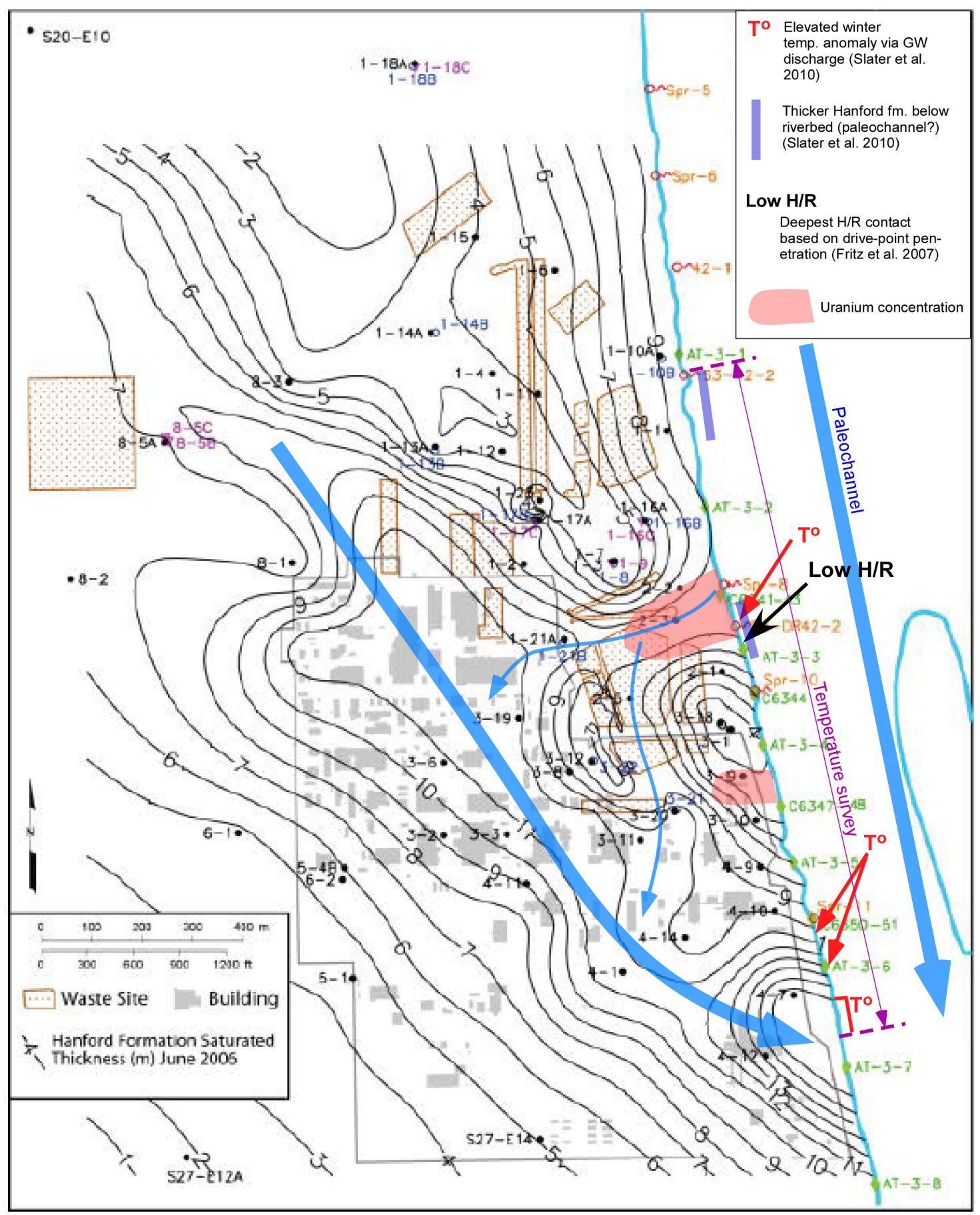

Figure 2.2. Paleochannels in relation to interpreted groundwater-river exchange points identified by Slater et al. (2010) 


\subsubsection{Holocene Deposits}

The most recently deposited sediment consists of reworked Hanford formation sandy gravel, eolian silt and sand, and/or backfill of previously excavated sediment, coal plant ash waste, etc. These deposits underlie most of the 300 Area and their typical thickness is 1 to $6 \mathrm{~m}$, forming the upper portion of the vadose zone. The backfill materials at the South Process Pond extend 5 to $6 \mathrm{~m}$. Much of the 300 Area inside the fence is covered by pavement and building foundations.

The eolian sands and silts that mantle the Hanford formation are well above the historic water table and therefore are not significant to the overall hydrogeologic framework (Fritz et al. 2007). Holocene alluvium along the Columbia River, however, may impede groundwater flow in the hyporheic zone. Deposition of Holocene alluvium by the Columbia River forms a zone of lower permeability (relative to the Hanford formation) and restricts groundwater exchange with the Columbia River (Fritz and Arntzen 2007). Furthermore, the heterogeneous nature of sediments at the aquifer-river interface results in preferential flow paths for groundwater that vary temporally, depending on river stage (Slater et al. 2010).

\subsection{Hydrology}

The hydrology of the 300 Area is dominated by river-stage variations that are significant. The hydrologic system in the 300 Area includes river-stage fluctuations, bank storage and seepage in the hyporheic zone, recharge-driven vadose zone flow, imbibition and drainage in the capillary fringe and lower vadose zone sediments, and preferential flow through the sandy gravel sequence of the Hanford formation.

\subsubsection{Surface Water}

Surface water hydrology at the 300 Area is driven by fluctuations in Columbia River stage. These fluctuations range from seasonal response to watershed-scale snowmelt and runoff to hourly fluctuations from the release of upstream waters to meet electric power demand. Daily discharge of the Columbia River at Priest Rapids Dam ( $74 \mathrm{~km}$ distant) averages $\sim 2210 \mathrm{~m}^{3} / \mathrm{s}$ and ranges from $\sim 570$ to $4780 \mathrm{~m}^{3} / \mathrm{s}$ (Figure 2.3).

The average range of diurnal river-stage variation is large $(\sim 0.5 \mathrm{~m})$ relative to the average piezometric head drop $(\sim 0.2 \mathrm{~m})$ from over a kilometer inland to the river and causes twice daily groundwater flow reversals that allow substantial exchange of river water and groundwater in the near-shore aquifer (Zachara et al. In Press, Figure 5). ${ }^{1}$ A review of hourly Columbia River stage measurements at the 300 Area from November 1991 through April 2007 revealed the average annual maximum river level that occurs in late spring is $1.7 \mathrm{~m}$ higher than the grand mean of $105.4 \mathrm{~m}$ above mean sea level (MSL) with a maximum of 3.0 higher than the grand mean. The sustained high water during snowmelt often results in river-water intrusion over $100 \mathrm{~m}$ inland. River water has been observed in the IFRC well field during 4 of the past 5 years. The 300 Area is a location of discharge for the regional unconfined aquifer, but the

\footnotetext{
${ }^{1}$ Zachara JM, PE Long, G Bargar, JA Davis, P Fox, J Fredrickson, MD Freshley, A Konopka, C Liu, JP McKinley, M Rockhold, KH Williams, and SB Yabusaki. In Press. "Persistence of Uranium Groundwater Plumes: Contrasting Mechanisms at Two DOE Sites Existing in the Groundwater-River Interaction Zone." Journal of Contaminant Hydrology.
} 
Columbia River stage is much larger than the regional response of the aquifer, resulting in gradient reversals. Lower river stages typically occur from late summer through fall (Figure 2.3).

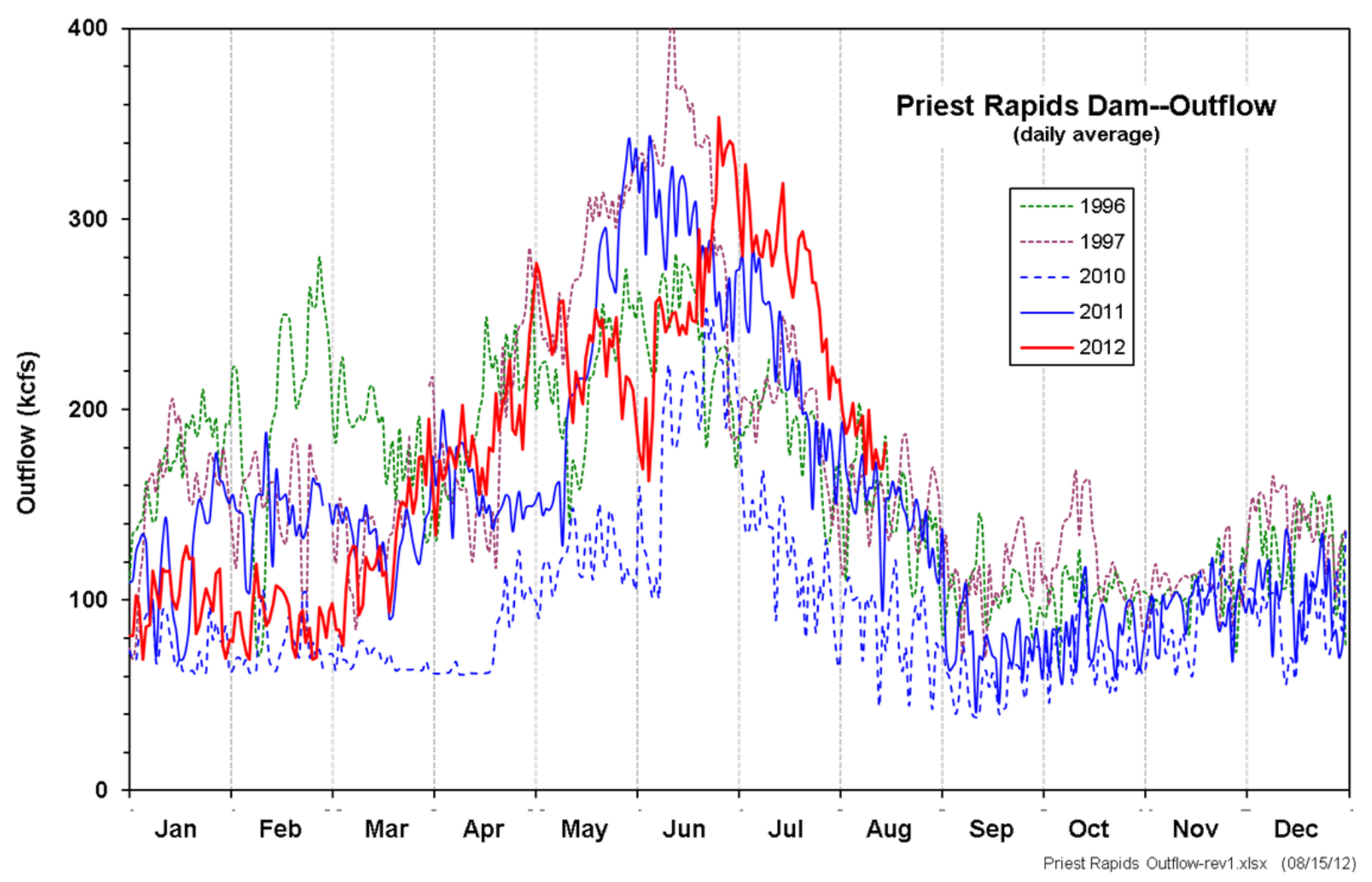

Figure 2.3. Priest Rapids Dam discharge hydrograph for selected years

\subsubsection{Vadose Zone}

Estimates of annual average recharge for the 300 Area range from $2 \mathrm{~mm} / \mathrm{y}(0.08$ in./year) for undisturbed, vegetated conditions to approximately $62 \mathrm{~mm} / \mathrm{y}$ (2.4 in./year) for disturbed, unvegetated areas (DOE-RL 2010). The difference in recharge between these two sites illustrates the importance of vegetative cover and evapotranspiration. Higher recharge values may occur locally and episodically during thunderstorms, rapid snowmelt, discharge associated with facilities, and dust control during remediation.

The role that infiltration of meteoric water may play in transporting uranium from the vadose zone to the periodically rewetted zone (PRZ) in the 300 Area has been investigated at the IFRC. A field-scale effort is underway at the IFRC site to study the potential for meteoric water to transport uranium to the PRZ using time lapse electrical resistivity tomographic (ERT) imaging. ${ }^{1}$ The primary objectives of this effort are to 1) determine the feasibility of monitoring vadose zone moisture transport using surface-based ERT measurements, and 2) determine if meteoric water is reaching the PRZ over an annual climate cycle. An array of ERT surface electrodes was installed at the IFRC site in November 2011 and has been collecting data continuously since then, providing approximately four complete surveys per day for a total

\footnotetext{
${ }^{1}$ Johnson T. 2008. Personal communication with Tim Johnson (Pacific Northwest National Laboratory).
} 
of 10 months as of September 2012. A complementary data set including hourly precipitation, atmospheric temperature, and subsurface temperature at 2-ft-depth intervals is also being collected. Crosshole ground-penetrating radar and neutron moisture logs are being periodically collected within access tubes installed to a depth of $10 \mathrm{ft}$, which started in March 2012.

Baseline ERT images collected prior to monitoring (November 2011) revealed a layered vadose zone structure including a coarse-grained surface cover to a depth of approximately $1.5 \mathrm{~m}$, followed by finer-grained fill materials to a depth of approximately $4 \mathrm{~m}$, followed by native Hanford formation materials to the water table at a depth of approximately $10 \mathrm{~m}$ (Figure 2.4). A comprehensive analysis of precipitation and ERT data collected from November 2011 to April 2012 showed that after a total of $5.6 \mathrm{~cm}$ of rain over this period, pore water migrated quickly through the upper coarse-grained zone, and then remained bound within the fine-grained unit (Figure 2.5). As of mid-April 2012, ERT images provided no evidence that saturation had increased within the native Hanford formation materials.

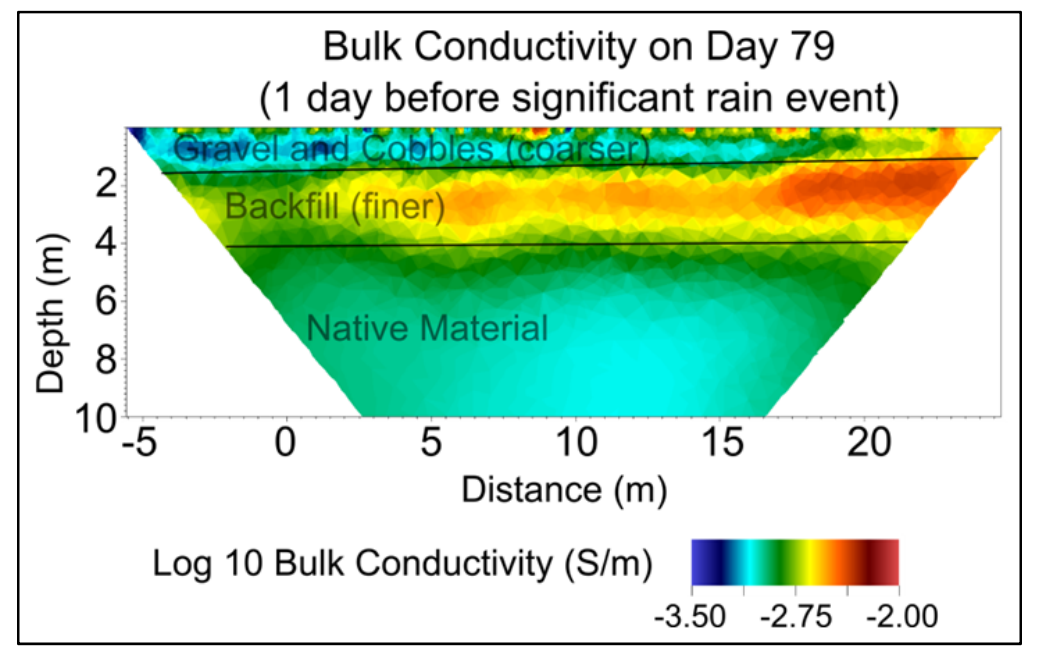

Figure 2.4. Bulk conductivity prior to rain events in April 2012. Conductive zones are indicative of soil texture as labeled.

ERT, precipitation, and temperature data collected from April through August 2012 were analyzed. The ERT monitoring results exhibited significant increases in conductivity within the upper vadose zone; less dramatic changes occurred lower in the section near the water table. Changes in the upper vadose zone were correlated with both temperature and precipitation events. However, subtle changes in the lower vadose were not correlated with temperature, suggesting the possibility of moisture movement just above the periodically rewetted zone. As a result, some uncertainty exists as to whether precipitation received at the surface reaches the water table or is eventually lost to the atmosphere during periods of evapotranspiration. A more detailed analysis is underway to remove temperature effects and determine more conclusively whether moisture is migrating downward to the periodically rewetted zone and water table.

\subsubsection{Groundwater Flow}

Detailed descriptions of hydrogeology in the 300 Area are available in the DOE-RL (2010) report and in earlier published reports (e.g., Williams et al. 2007; Lindberg and Bond 1979; and Gaylord 
and Poeter 1991). A description of hydrostratigraphic units used in computer simulations of groundwater flow is presented by Williams et al. (2008).

The water table is located in the high permeable gravel of the Hanford formation. The total thickness of the Hanford formation typically ranges from 13 to $19 \mathrm{~m}$ (43 to $62 \mathrm{ft}$ ). The saturated thickness ranges from $3 \mathrm{~m}$ to over $10 \mathrm{~m}$ over most of the area covered by the 300 Area uranium plume. The saturated portion of the Hanford formation is highly permeable compared to the underlying Ringold Formation, with hydraulic conductivity measured in many hundreds to thousands of meters per day. Most of the contamination and groundwater flow in the unconfined aquifer occurs in the saturated Hanford formation.

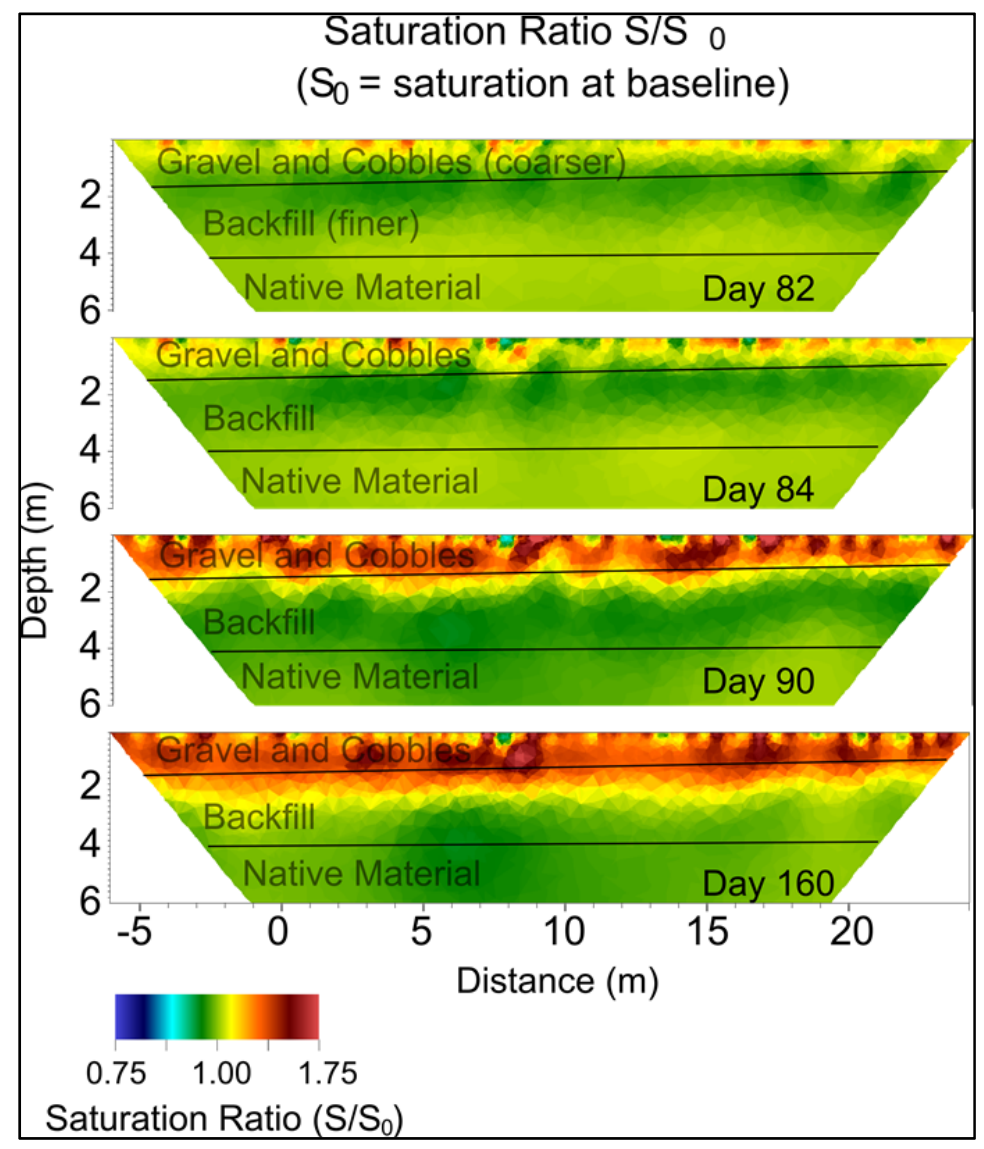

Figure 2.5. Electrical resistivity tomographic-derived change in saturation after a series of significant rain events. The downward migration of moisture is inhibited by the finer-grained backfill layer.

Hydraulic conductivity measurements have been performed in wells as part of recent characterization efforts for the limited field investigation (Williams et al. 2007) and a volatile organic compound investigation (Peterson et al. 2008a). For the Hanford formation, hydraulic conductivities measured in slug tests in individual wells range from $\sim 300 \mathrm{~m} / \mathrm{d}$ to greater than $\sim 2000 \mathrm{~m} / \mathrm{d}$. Hydraulic conductivities measured for the Ringold Formation range from less than $1 \mathrm{~m} / \mathrm{d}$ to $\sim 40 \mathrm{~m} / \mathrm{d}$. The IFRC site completed hydrologic testing shortly after the well field was installed. The testing program included both constant rate injection tests in 14 fully screened wells and electronic borehole flowmeter (EBF) measurements of both ambient and dynamic flow (Zachara 2009). The constant rate injection tests provided 
depth-averaged hydraulic conductivity values that ranged from $4600 \mathrm{~m} / \mathrm{d}$ to $11,000 \mathrm{~m} / \mathrm{d}$ (Figure 5 from Zachara 2009). The EBF profiles, collected at 30- to 60-m depth increments characterized the variability of flow rates in the boreholes and allowed the depth-averaged measurements to be distributed vertically to characterize heterogeneity (Figure 4 from Zachara 2009). The measurements at the IFRC show a consistent intermediate zone of lower hydraulic conductivity with higher conductivity zones above and below. The EBF profiles give an indication of local-scale heterogeneities in the unconfined aquifer that result in vertical borehole flows (discussed in later sections) that may impact observations and behavior of the uranium plume.

In general, regional groundwater flow converges in the 300 Area (Figure 2.6). During periods of high Columbia River flow, the gradient is more southerly and during periods of low Columbia River stage, flow becomes more easterly. Groundwater velocities within the 300 Area uranium plume can be very high during periods of rapidly increasing or decreasing river stage, with documented tracer velocities exceeding $15 \mathrm{~m} / \mathrm{d}$ (Vermeul et al. 2009). The periods of steep gradients are usually short-lived, and are typically offset by many reversals in flow direction. The result of the frequent flow reversals and an undulating Hanford-Ringold Formation contact along the river shore (Fritz et al. 2007; Slater et al. 2010) is a relatively small net flux of uranium-containing groundwater to the Columbia River. Localized groundwater flow velocities may be higher than net movement derived from tracking tracers because of the frequent reverses in flow caused by Columbia River stage fluctuations.

The result of Columbia River stage fluctuations is highly dynamic hydrologic conditions in the 300 Area. Columbia River stage is measured at a gauging station at a water intake structure east of the former 338 Building. River stage fluctuates with daily, weekly, seasonal, and multiyear cycles. As the river stage rises and falls, the pressure wave propagates inland through the unconfined aquifer. Differences in hydraulic conductivities can cause local variations in the response to river-stage changes. Hydraulic gradients also change rapidly as river stage varies. The water table moves vertically several meters, creating a zone that is alternatively saturated and unsaturated. Differences in aquifer properties (permeability) cause variations in the response of wells at different locations in the 300 Area. Generally, wells adjacent to the river show higher variation in response to river-stage changes than wells located at increasing distance from the shoreline. River-stage variations result in river-water intrusion into the unconfined aquifer. Depending on a variety of factors (e.g., sediment hydraulic properties, height of river stage, and duration of high river stage), river water may flow inland laterally along the water table or may mix with groundwater. River water intrusion likely occurs preferentially in paleochannels noted by Fritz et al. (2007) and Slater et al. (2010).

\subsubsection{Hyporheic Zone and Discharge to the Columbia River}

Groundwater in the 300 Area discharges to the Columbia River through the hyporheic zone by upwelling through the riverbed and along the river banks in springs and seeps. River water is stored in groundwater near the river and discharges along with the 300 Area groundwater. The large variation in river-stage results in reversals of gradient and discharge to and from the river into groundwater. Overall, there is a net discharge of groundwater and uranium to the Columbia River. Several estimates have been made of the discharge of uranium to the river at the 300 Area. 


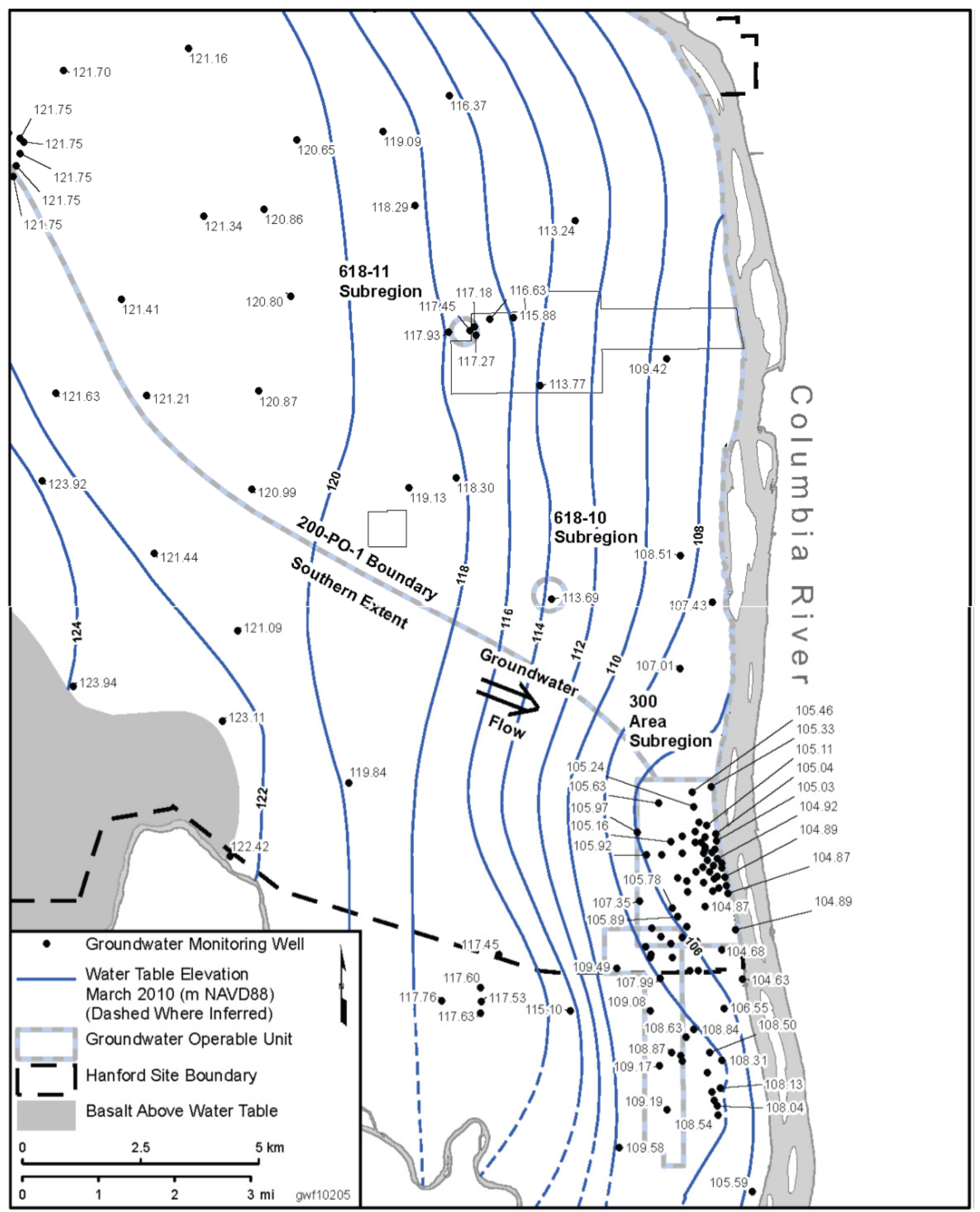

Figure 2.6. Water table elevation contours for the 300 Area, March 2010 
Fritz and Arntzen (2007) characterized the hyporheic zone and uranium discharge to the Columbia River, accounting for river-stage variation. A previous estimate for uranium discharge of $430 \mathrm{~kg} / \mathrm{y}$ (DOE-RL 1994) did not account for the impact of groundwater/river interactions. Piezometers and continuous water quality monitoring probes were installed in the near-shore river gravel. Calculations of uranium discharge were made based on high temporal resolution measurements of hydraulic gradient and contaminant concentrations. Fritz et al. (2007) estimated the total annual uranium discharge to the Columbia River to be $200 \mathrm{~kg} / \mathrm{y}$, but stated this may be an overestimate of discharge because the flux estimate used concentrations from the center of the uranium plume and the potential area of discharge likely was too high. This estimate will be compared with other estimates based on numerical modeling in a later section of this report.

The recent RI/FS report (DOE-RL 2010) provided an estimate of approximately $40 \mathrm{~kg} / \mathrm{y}$ uranium discharge to the river and an additional $10 \mathrm{~kg} / \mathrm{y}$ by withdrawal to a water supply well for aquariums used for fisheries research in the 331 Building. These estimates are based on modeling by Williams et al. (2008) and interpretations of monitoring data. Williams et al. (2008) calibrated a model of the 300 Area and used the model to estimate net water flux to the river. The calculated water fluxes and observed plume concentrations were used to develop the estimate of uranium flux to the Columbia River.

Groundwater and uranium do not discharge uniformly to the Columbia River in the 300 Area. Slater et al. (2010) characterized groundwater discharge to the Columbia River using electrical imaging in conjunction with fiber-optic distributed temperature sensors. They installed a fiber-optic temperature sensing cable in the Columbia River adjacent to the 300 Area and performed waterborne electrical imaging by boat in a series of lines parallel to the shoreline to mid-channel. The study showed a spatially and temporally complex pattern of surface water-groundwater exchange, controlled by the thickness of transmissive sediments, with exchange focused at springs that in some cases are associated with paleochannels. Temporal fluctuations in Columbia River stage drive the flow of water between the unconfined aquifer and river. The electrical imaging resolved variability in the contact between the Hanford and Ringold formations along the 300 Area shoreline and identified places where the Ringold Formation is in contact with the riverbed, delineating where paleochannels discharge to the river. Ground-penetrating radar (GPR) surveys were performed as well as inspection of previous surveys. The GPR survey results along the streambed correlate with the temperature data set to provide evidence of paleochannels locally enhancing surface water-groundwater exchange. The distributed temperature sensors use the difference between groundwater and river temperatures during different seasons (summer and winter) to identify areas of groundwater discharge to the river. The observed temperature anomalies appear to be correlated with lithology, occurring at locations where Hanford Site sediments are thickest and the Ringold Formation is at depth. These anomalies are associated with known springs/seeps (Williams et al. 2008). Slater et al. (2010) conclude that highly permeable paleochannels are suspected to exist at the contact between the Hanford and Ringold Formations and likely provide localized preferential flow paths for enhancing surface water-groundwater exchange. This variability likely impacts the estimate of Fritz et al. (2007) for uranium discharge to the Columbia River, suggesting that it occurs in localized areas at the 300 Area shoreline, rather than broadly.

\subsection{IFRC Hydrogeology}

The 300 Area IFRC is situated within the footprint of the South Process Pond, which was used for disposal of nuclear fuels fabrication wastes from 1943 to 1975 . The site is designed for monitoring 
uranium concentrations and tracer tests within a triangular configuration of 36 monitoring wells (Figure 2.7). The configuration of the well field allows study of varying groundwater flow paths in response to the daily and seasonal variations of water table elevation and flow direction. Surface and down-hole geophysical measurements, along with water sampling and analysis, are used to monitor the migration and evolution of injected tracers and naturally developing plumes (e.g., Chen et al. 2012; Ma et al. 2011; Ma et al. 2012). Eight different field experiments have been performed at the IFRC, including both injection waters of varying uranium concentrations and passive monitoring experiments. Tracers have been used in all of the field experiments to track the movement of groundwater and injected solutions through the well field. The tracers used include sodium bromide, potassium chloride, sodium chloride, sodium fluoride, and deuterium. Initially, two injection experiments were performed on the newly constructed well field using water with uranium concentrations similar to those observed at the IFRC. Cooled water was also injected as a tracer. A higher concentration tracer test was performed to evaluate the utility of using the ERT monitoring network to characterize and track the tracer plume. Two different desorption tests were performed using groundwater with lower uranium concentrations than the IFRC and a sorption test was performed using waters with higher uranium concentrations.

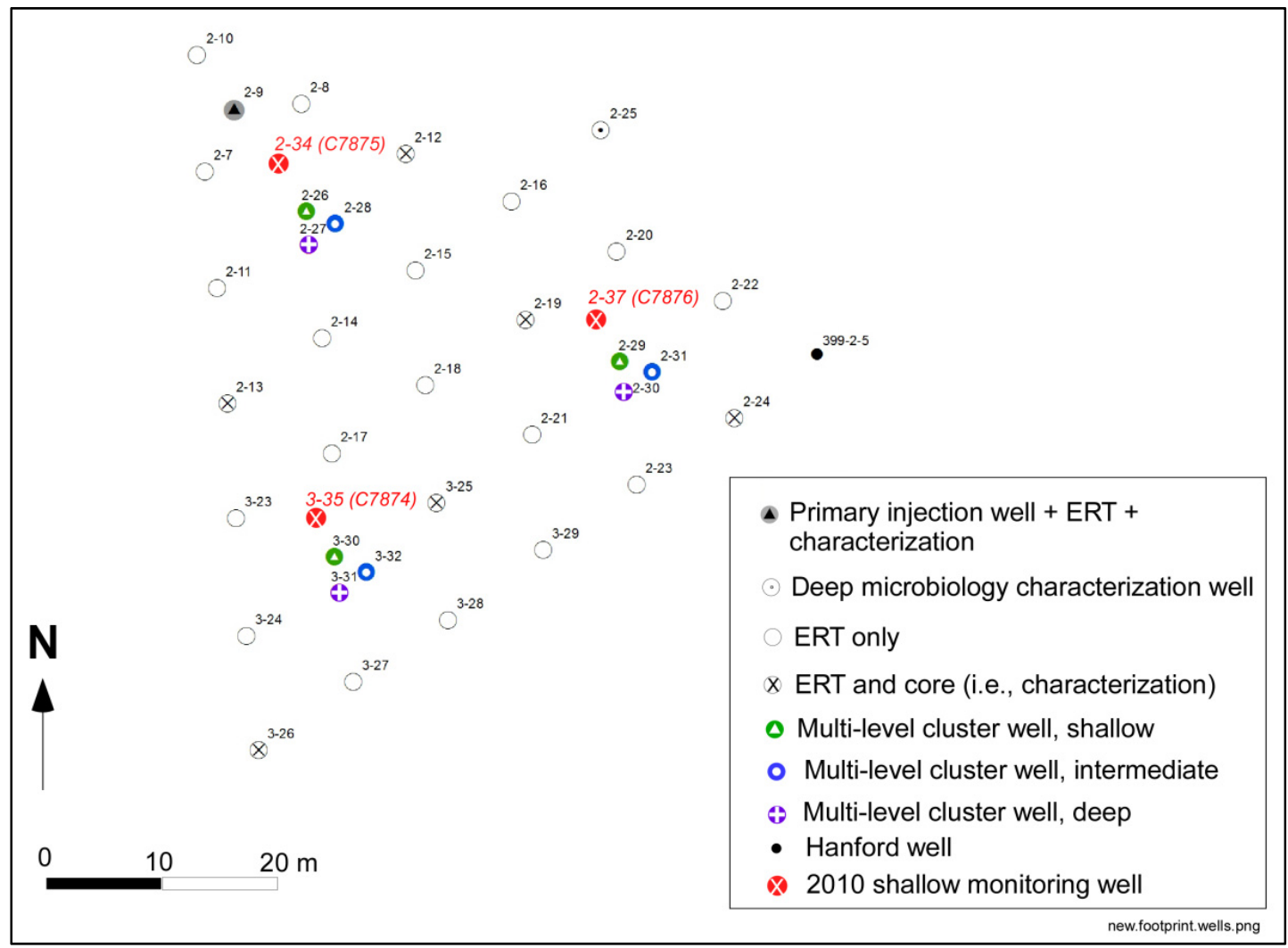

Figure 2.7. IFRC well locations

Detailed characterization at the IFRC revealed insights into the physical characteristics of the Hanford formation. Sediments from core samples obtained during well installation were characterized in the laboratory for physical, chemical, and microbiologic properties. These properties were correlated with surface and down-hole geophysical measurements and used to develop a three-dimensional geostatistical model of the experimental domain (Murakami et al. 2010). Later work by Chen et al. (2010) included 
data from the 2009 tracer test to update the three-dimensional hydraulic conductivity field. Murray et al. (2012) reported on measurements of physical and mineralogical properties measured to establish a geochemical heterogeneity model of the IFRC site, including grain-size distribution, surface area, extractable iron, and mineralogy. The particle size distribution ranged from coarse gravel, to sandy gravel, to silty sandy gravel, and finally to silt for the Hanford and Ringold Formations sediments. Sediments at the site fell into two textural classes: muddy sandy gravels characteristic of the Hanford formation and mud-dominated sediments characteristic of the Ringold Formation. The Hanford formation sediments that host the uranium plume were observed to be coarse, with mean gravel content of approximately $65 \%$, whereas the mean gravel content in the Ringold Formation was approximately $7 \%$. The gravel fraction is dominated by coarse, rounded river cobble (Murray et al. 2012).

Johnson et al. (In Press ${ }^{1}$ ) characterized the IFRC and surrounding area using surface and subsurface geophysics. They used three-dimensional ERT in conjunction with geostastically based inversion constrained by laboratory measurement of electrical conductivity on core samples from the site.

The inversion of the ERT characterization data produces a layered structure that maps horizontally continuous facies within the well field (Figure 2.8). Further interpretation and validation of these results in the saturated zone are enabled by comparison to core measurements and EBF profiles.

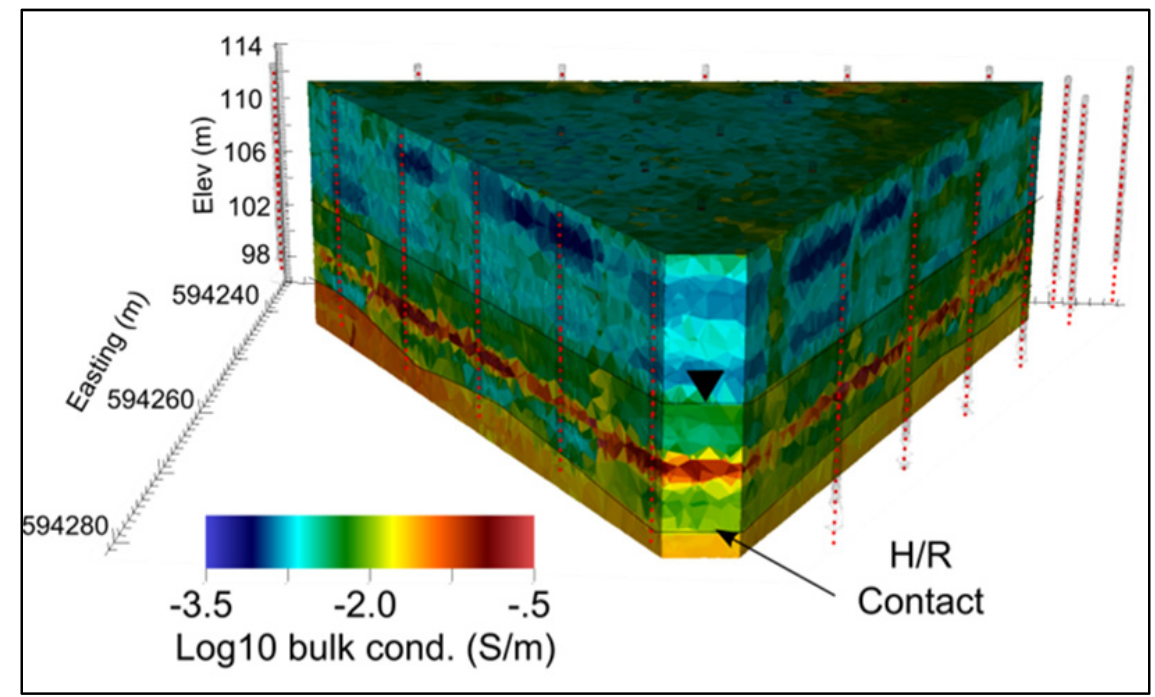

Figure 2.8. Results of the ERT inversion using known values. The known values are honored exactly; the ERT data are fit to semivariograms.

Figure 2.9 shows a comparison of the saturated zone ERT inversion results and field-scale hydraulic conductivity values measured by EBF testing along several boreholes (results for other boreholes are similar). The high electrical conductivity zone ( 100-102 m elevation) is prevalent in each plot, and consistent with the core-scale hydraulic conductivity measurements, corresponds generally to lower values.

\footnotetext{
${ }^{1}$ Johnson TJ, RJ Versteeg, M Rockhold, LD Slater, D Ntarlagiannis, WJ Greenwood, and JM Zachara. In Press. "Characterization of a Contaminated Well field Using Three-Dimensional Electrical Resistivity Tomography Implemented with Geostatistical, Discontinuous Boundary, and Known Conductivity Constraints." Geophysics.
} 

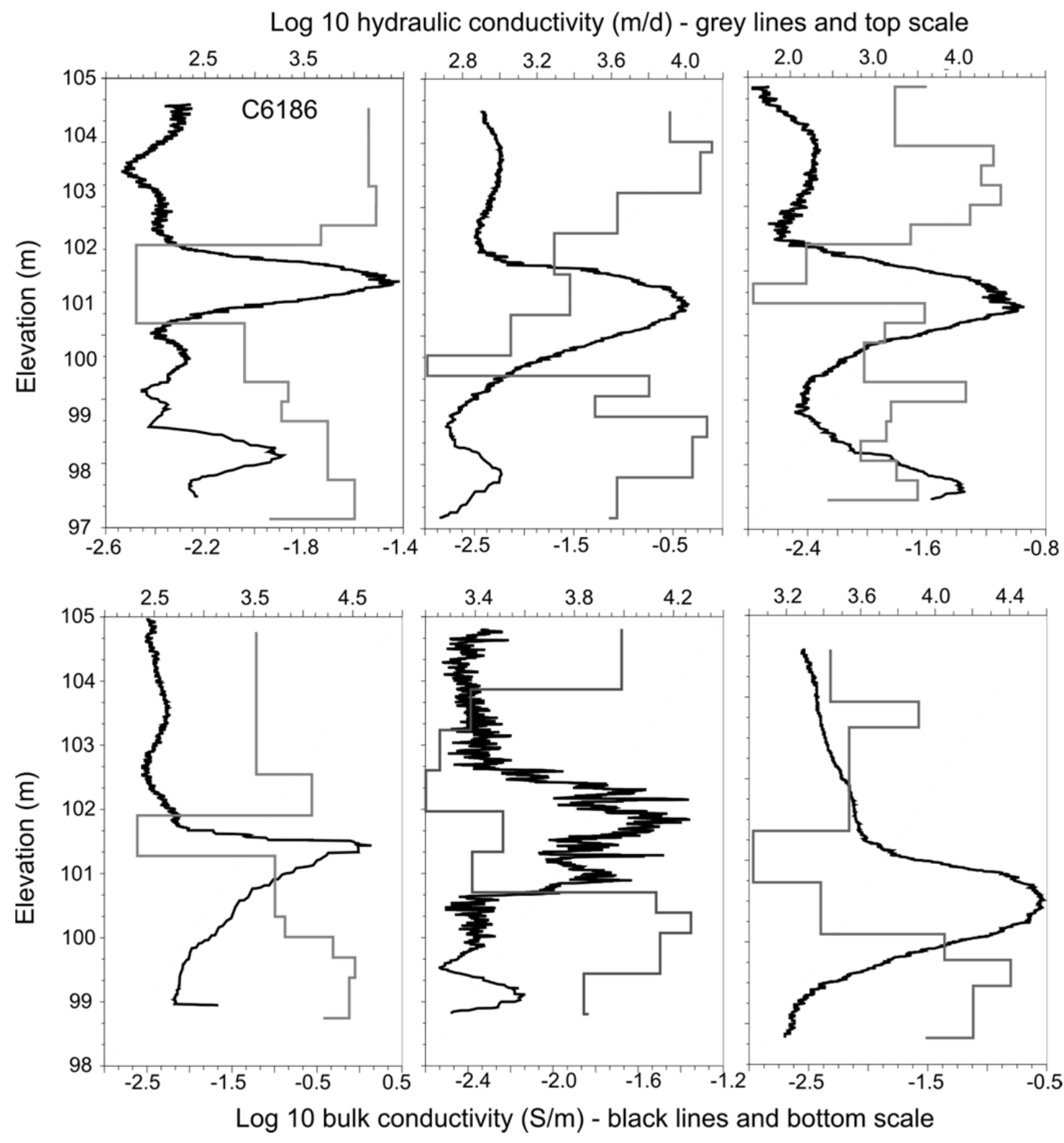

Figure 2.9. Comparison of $\mathrm{K}$ estimated with borehole electromagnetic flowmeter and electrical conductivity extracted from the ERT inversion in the same wells. The low hydraulic conductivity regions are correlated to the pervasive high-conductivity unit in each well.

The high electrical conductivity, low-permeability zone revealed in the saturated Hanford formation was noted by Vermeul et al. (2011) as a primary contributor to vertical borehole flow within wells that fully penetrate the saturated zone. This work shows that unit to be continuous throughout the well field. The low-permeability zone has broad implications that will be discussed in later sections of this report.

The comparison between electrical conductivity and hydraulic conductivity (both core and field scale) is diagnostic of soil texture distribution within the saturated zone. Two cores located within the elevated electrical conductivity zone exhibited fine-grained texture and presumably high surface area in comparison to the other cores, suggesting that the high electrical conductivity zone within the saturated 
portion of the Hanford formation is significantly influenced by surface conduction. The lower hydraulic conductivity for this region suggests the porosity is somewhat lower and/or the effective grain diameters are smaller, relative to the overlying and underlying regions. Above and below the high electrical conductivity zone, coarser textured cores are associated with lower conductivity values and higher hydraulic conductivity values, consistent with EBF profiles. The different inversions reveal a pervasive, thin, horizontal high electrical conductivity zone, confirming the low-permeability zone identified in the EBF profiles.

Tracer directions and velocities from experiments conducted at the IFRC are highly dependent on river-stage conditions. It was not always feasible to report a tracer drift velocity based on experiments because river stage was highly variable and resulted in tracers moving back and forth across the well field. One test performed in March 2009 involved a nonreactive tracer injection monitored under a relatively stable hydrologic regime that allowed an estimate of tracer drift velocity to be made. The experiment was conducted using a bromide tracer and cooled groundwater injected at a constant rate into a well at the northwest apex of the well field. Tracer concentrations were monitored for several weeks following the injection. The observed tracer transport indicates the presence of a relatively narrow preferential flow path through the central portion of the well field, generally consistent with a channel feature based on local lows in the Hanford and Ringold contact. Average velocity estimates increased at downgradient locations from the injection well. High velocities between wells coincided with a steep drop in Columbia River stage (Figure 2.10) but slowed during times when the river was rising or relatively constant. In composite over the length of the well field, the average calculated drift velocity was approximately $11 \mathrm{~m} / \mathrm{d}$. Localized average velocities across the well field ranged from 11 to $25 \mathrm{~m} / \mathrm{d}$, which are consistent with other observed tracer drift velocities in the 300 Area (Vermeul et al. 2009).

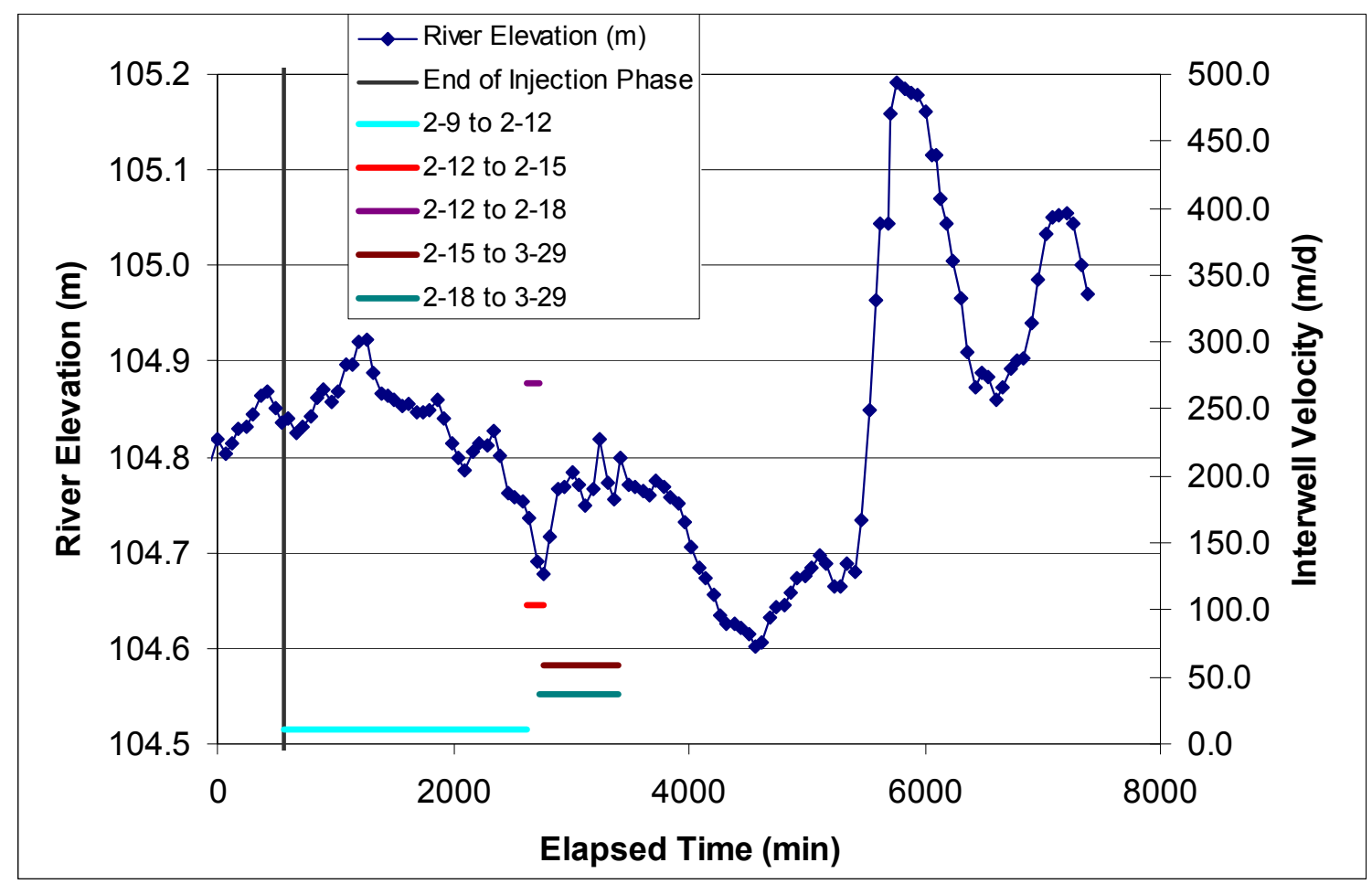

Figure 2.10. Interwell tracer-drift velocities relative to Columbia River stage 
Another set of tracer tests was conducted during a passive monitoring experiment (McKinley et al. In Press $^{1}$ ) in June 2010 to determine groundwater velocities at high river stage. The tracer tests involved injection of small quantities of fluoride, bromide, and chloride solutions ( 450 to $570 \mathrm{~L}$ of tracer solution) and measuring arrival at nearby wells. These resulting groundwater velocities ranged from 13 to $25 \mathrm{~m} / \mathrm{d}$, also consistent with other observations at the IFRC and elsewhere in the 300 Area.

Tracer tests conducted at the IFRC have revealed that river-stage fluctuations and gradient changes can cause strong variations in tracer and contaminant plume movement. Tracer plumes have been observed to move back and forth at individual monitoring well locations in response to river-stage changes. During the first test conducted at the IFRC in November 2008 (Zachara 2009), large river-stage fluctuations resulted in drift of the tracer plume center of mass to the west, out of the IFRC well field during early stages of the experiment and back into the well field at later stages. A gradient flow plot showing the computed trajectory of tracer added to the IFRC (in well 2-29) during the high river stage shows a tortuous flow path with numerous reversals of direction (Figure 2.11). This illustrates the influence of gradient reversals caused by the daily and weekly river-stage variation cycles.

Twenty-six of the 35 wells in the IFRC well field were fully screened through the saturated zone in the Hanford formation at the time of their installation; the remaining 9 wells are depth discrete and in three-well clusters. Vertical wellbore flows were first observed in select IFRC wells in November 2008 during EBF testing. The fully screened wells penetrated all three hydraulic conductivity zones (described previously in this section. Frequent river-stage fluctuations created hydraulic pressure variations between the upper and lower zones. Differing degrees of connectivity between the upper and lower high hydraulic conductivity zones and an overall complex hydraulic conductivity structure resulted in head differences that drove wellbore flows both upward and downward. Head differences between the shallow and deep zones were well correlated with wellbore flow (Vermeul et al. 2011). Because of the high hydraulic conductivities in the well field, only a small amount of head difference was required to induce vertical flow. Vertical flows strongly impact measured uranium concentrations in the wells during periods of aquifer stratification (discussed in later report sections). Periods of downward flow were dominated by higher concentrations in the upper aquifer, while periods of upward flow were dominated by lower concentrations from the deep zones. These variations made quantitative evaluation of monitoring data and tracer concentrations during experiments problematic.

Tracer tests conducted at the IFRC have illustrated differences in response at different depths. This was observed in the first tracer test at the IFRC in October 2008. In this test, tracer concentrations in the three wells of the northern-most multilevel well cluster $(2-26,2-28,2-27)$ indicated that arrival in the middle zone monitoring well significantly lagged with respect to the upper and lower depth intervals, and that concentrations remained elevated in this zone throughout the monitoring period while tracer elution occurred in the upper and lower zones (Figure 2.12). This response is consistent with observations of the lower permeability intermediate zone in EBF profiles. The response in the upper zone (Figure 2.11) showed a relatively strong tracer response to river-stage variability observed in the upper zone relative to that observed in the lower zone resulting from connectivity to the Columbia River, and lower permeability over the middle portion of the aquifer, confirming the effect of the lower permeability zone in isolating response to changes in river stage.

\footnotetext{
${ }^{1}$ McKinley JP, J Zachara, CT Resch, RM Kaluzny, MD Miller, VR Vermeul, BG Fritz, and JV Moser. In Press. "River Water Intrusion and Contaminant Uranium Contributions to Groundwater During the Annual Spring Rise in Columbia River Stage at the Hanford Site 300 Area, Washington.” Environmental Science \& Technology.
} 


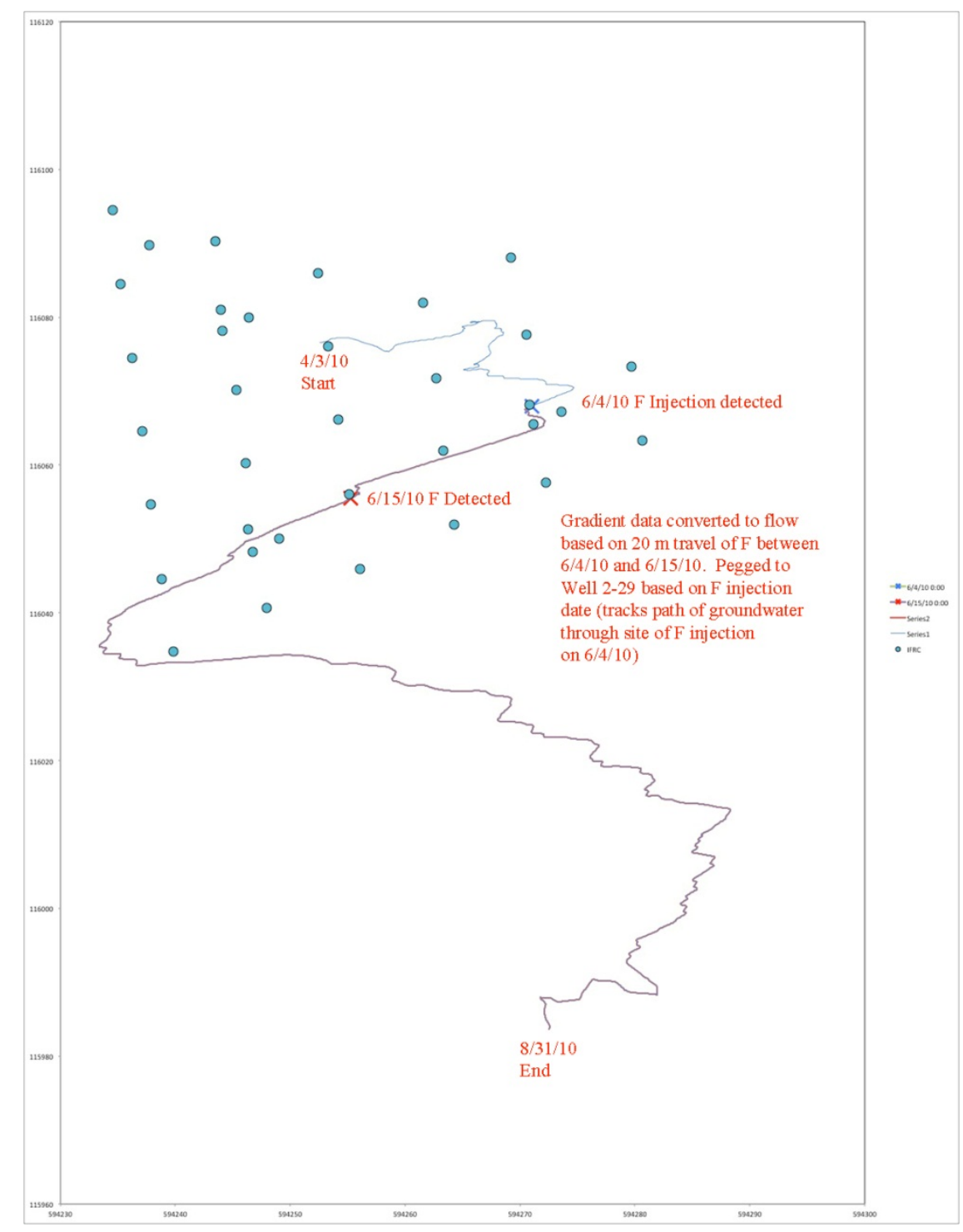

Figure 2.11. Gradient flow plot showing the computed trajectory of tracer injected in well 2-29 on April 2010

\subsection{Area Modeling Studies}

A variety of modeling efforts have been conducted for the uranium plume in the 300 Area. The efforts range from three-dimensional models of the 300 Area to cross-section models.

DOE-RL (1994) conducted a three-dimensional modeling investigation of the 300 Area uranium plume using the PORFLO-3 code. The model domain included all of the 300 Area. No-flow boundaries were specified on the top and bottom of the domain and time-dependent head conditions were used on the sides to account for hourly fluctuations in Columbia River stage. Transport of uranium was accounted for by a constant $\mathrm{K}_{\mathrm{d}}$ that was varied over a range in different simulations. The simulations evaluated dissipation of an initial distribution of the U(VI) plume, but did not consider a continuous source. The approach assumed remediation of uranium by removal. The model predicted a maximum flux of U(VI) to the river of $15 \mathrm{~kg} / \mathrm{y}$. 

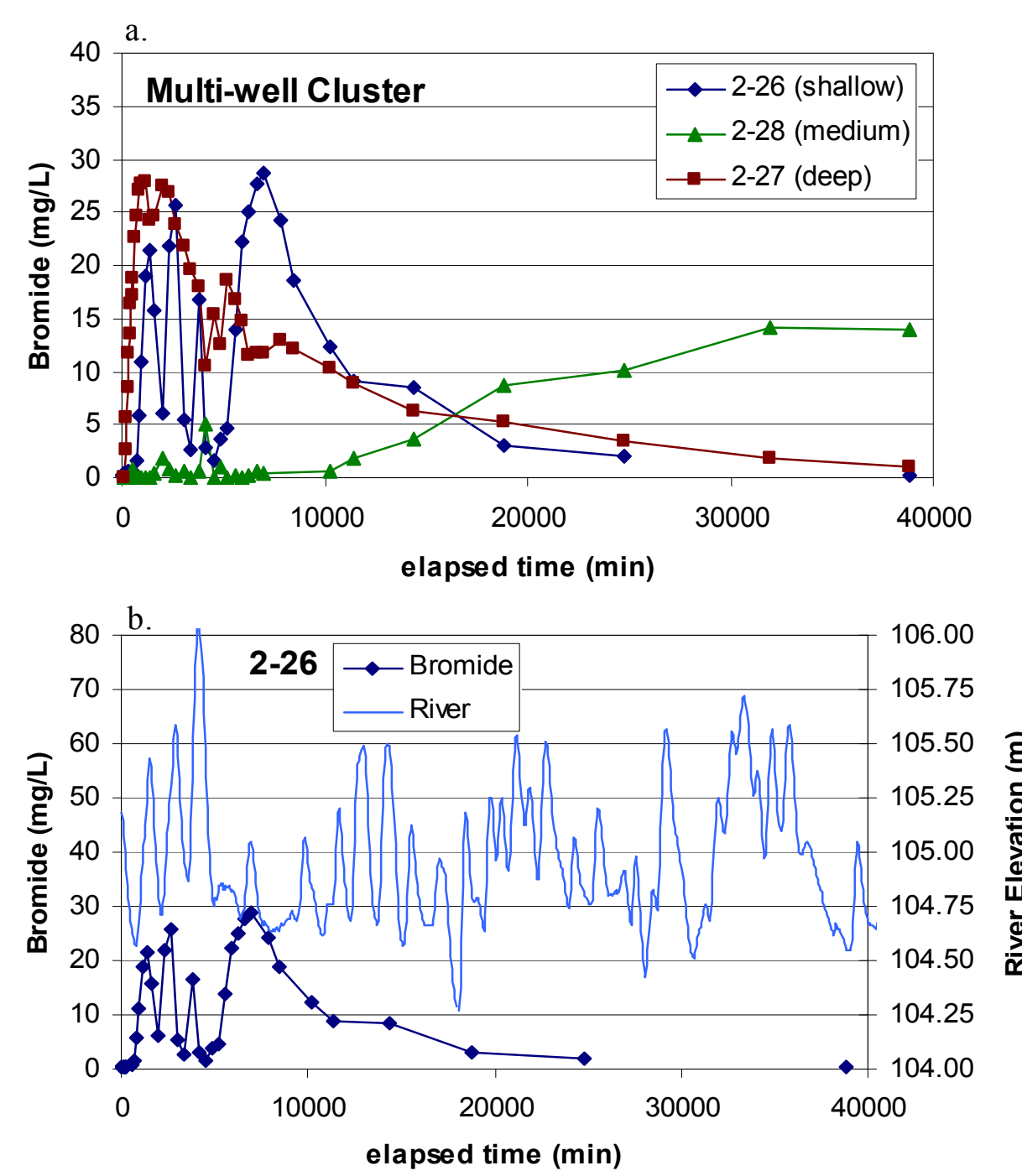

Figure 2.12. a) Bromide arrival in northwest multilevel well cluster. Note lag in arrival in well 2-28 and the significant differences between shallow and deep wells. b) Bromide concentrations in shallow well 2-26 show some correlation with complex river-stage changes over the experiment duration.

Williams et al. (2008) developed several large-scale numerical groundwater flow models of the 300 Area using the STOMP simulator. The large-scale model spanned $\sim 3 \mathrm{~km}$ of shoreline and extended $\sim 1 \mathrm{~km}$ inland to encompass an area larger than the current existing uranium plume. The models used updated hydrostratigraphy from previous interpretations of the 300 Area and were calibrated using hourly water-level data from a monitoring network that existed in 1991 to 1993 . The calculated water flux suggested that less than one pore volume of the uranium plume discharges to the Columbia River annually. A higher-resolution, smaller-scale model was developed to test the impact of finer vertical grid spacing to capture the fluctuating water table. Both model domains included the lower portion of the vadose zone to capture water table elevation variations during the simulations. High-resolution waterlevel and river-stage data were required to simulate dynamics of groundwater flow in the 300 Area. The 
models were used to estimate net water flux to the river and showed the importance of hydraulic properties on the flux estimates, particularly for the Hanford formation and river alluvium sediments.

Yabusaki et al. (2008) used a two-dimensional cross-section model through an area south of the South Process Pond and a one-dimensional vadose zone model to evaluate the conceptual model of processes controlling field-scale uranium behavior in the vadose zone-aquifer-river system. The models included variably saturated flow and multicomponent reactive transport. The model predicted the highly permeable Hanford formation allowed the hydrologic system to respond strongly to the wide range of diurnal and seasonal fluctuations of Columbia River stage. The model predicted transmission of the pressure wave more than a kilometer inland and river water mixing with groundwater more than $100 \mathrm{~m}$ inland. Solute mass above the high average water table was predicted to stay in place until high water levels release uranium to the groundwater and transport away from the source zone. The solute mass in the saturated zone was predicted to persist and serve as a long-term source of uranium to the groundwater.

Hammond and Lichtner (2010) and Hammond et al. (2011) presented results of high-resolution, three-dimensional reactive flow and transport simulations of U(VI) in the 300 Area. The simulation domain focused on the area of the South Process Pond as the source and extended to the southern boundary of the 300 Area. The domain did not include the North Process Pond or Process Trenches. The modeling effort focused on simulating uranium reactive transport and capturing the effects of rapidly changing river stages. Uranium release from a source zone, assumed to be the South Process Pond, was represented by the kinetic dissolution of a surrogate mineral, metatorbernite. The dissolution rate of metatorbernite was adjusted to yield the maximum U(VI) concentration observed at the site. Hammond and Lichtner (2010) used constant hydraulic properties for the Hanford formation, while Hammond et al. (2011) included stochastically generated heterogeneous permeability fields. Simulations were carried out for a single year, from December 25, 1992, to December 25, 1993. The simulations included calculation of the cumulative flux of water and U(VI) to the Columbia River. Although the model domain did not include the entire uranium plume, the estimate for the homogeneous permeability field was $22 \mathrm{~kg} / \mathrm{y}$ and the estimates for the heterogeneous permeability fields were tightly coupled in the range from approximately $19 \mathrm{~kg} / \mathrm{y}$ to slightly over $20 \mathrm{~kg} / \mathrm{y}$.

Ma et al. (2010) developed a reactive transport model of U(VI) transport in the 300 Area based on a cross section through the South Process Pond. The focus of their modeling effort was to incorporate a laboratory-characterized surface complexation model and multirate mass transfer processes. The hydraulic conductivity was assumed to be uniform within each geologic unit. The source zone was the South Process Pond and the simulations considered uranium transport to the Columbia River. River water was predicted to intrude as far as $330 \mathrm{~m}$ inland at high river stage, influencing groundwater composition and reactive transport. At the end of a 20-year simulation period, the model predicted only slightly more than $2 \mathrm{~g}$ of uranium had discharged to the Columbia River. Other reactive transport modeling activities focused on the kinetic geochemical release and retardation process of uranium in 300 Area sediments include Greskowiak et al. (2010 and 2011).

\subsection{Hydrogeology Implications}

The hydrogeologic framework provides the context for behavior of the uranium plume in the 300 Area. One of the most important factors controlling plume persistence is interactions between highly variable hydrologic conditions and subsurface geology in the 300 Area. The Hanford and Ringold contact 
that forms the basal surface of the plume displays complex surface topography and controls the thickness and the distribution of Hanford formation sediments, which are vastly different from the underlying Ringold Formation sediments in terms of hydraulic properties. This combination of geologic factors and properties creates an unusual hydrologic setting for the uranium plume where groundwater moves rapidly back and forth beneath the historic waste sites in response to river stage, but relatively small amounts of groundwater and uranium discharge to the river.

The Hanford formation sediments are characterized by extremely high permeability. An implication of this is that contaminants entering groundwater from the vadose zone will be rapidly dispersed laterally before there is much opportunity to mix within the aquifer. However, because of the highly variable hydraulic gradients resulting from river-stage fluctuations, vertical mixing does occur to some extent, especially in the zone of river-groundwater interaction close to the shoreline. The conditions that encourage mixing will be described in a later section of the report.

Studies at the IFRC conducted using geophysics, EBF testing, and tracer tests confirm the presence of a lower permeability intermediate zone within the Hanford formation. This zone is not observable in drilling logs or grain-size distributions, but has a large impact on the hydrologic system, resulting in vertical borehole flows that may have implications for monitoring, persistence of the uranium plume, and remediation approach. Implications of this zone to geochemical processes controlling persistence of the uranium plume are discussed in a later section of the report.

Estimates of uranium discharge to the Columbia River cover a wide range, based on different modeling assumptions and approaches. As seen by field characterization along the Columbia River shoreline, the discharge of uranium to the river is not uniform. This remains one of the key areas of uncertainty regarding persistence of the uranium plume in the 300 Area. 


\subsection{Trends in Monitoring Data and Uranium Plume Parameters}

Uranium concentrations have been measured in groundwater in the 300 Area since the early 1950 s. Inspection of monitoring data for the 300 Area shows multiyear trends associated with localized events of uranium mobilization to groundwater and migration within the plume. This section provides an update of groundwater monitoring data (through the summer of 2012) to examine the frequency and potential causes of these mobilization events, as well as the spatial and temporal pattern of their dissipation. Concentration trends in both time and space are evaluated relative to their implications for identification of possible source terms.

The approach was to examine monitoring trends in selected wells (near principal liquid water disposal facilities) relative to impacts from waste site operations, remedial activities, and water-level changes. Trend plots were examined for similarities and grouped to reflect potential sources, significant events, and contributions of uranium contamination to groundwater. These uranium concentration spikes in groundwater (as well as phosphate from an injection test) can be qualitatively tracked by their temporal signatures as they migrate towards the Columbia River, providing insights into transport pathways and rates. In this way, these temporal signatures function as large-scale tracer tests, not unlike those discussed in Sections 2.0 and 5.0.

This section includes estimates for parameters (area, volume, and uranium mass) that describe the uranium plume. Previous estimates made through 2007 were extended to January 2012. Sources of uncertainty for groundwater monitoring and plume parameters are also discussed.

\subsection{Relationships to River and Groundwater Levels}

Researchers have long recognized that river-stage impacts groundwater elevations and uranium concentrations in the 300 Area. Haney (1957) found that during high river stage (typically in May and June), groundwater flow was reversed and moved inland from the river. During these times, uranium concentrations in wells near the river decrease because of dilution (east of the North Process Pond and South Process Pond locations), while increases are noted in inland wells from uranium mobilized in the PRZ. Figure 3.1 illustrates the general relationships between uranium concentrations and water table elevations in groundwater monitoring wells near the North Process Pond and South Process Pond in response to river-stage increases.

Haney (1957) also observed that after high river stage the contaminated groundwater "drained" back towards the river over an estimated 6-month period. This observation was not backed by measurements or other documentation. The travel time between the North Process Pond and the river, during normal river stage was estimated to be 1 to 3 months. Intrusion of river water may dilute uranium concentrations in groundwater by a ratio of 1:500.

Prior to construction of McNary and Priest Rapids dams (1956 and 1961, respectively) and regulation of river stage (when the process ponds were in their peak of operation), groundwater levels may have risen 2 to $3 \mathrm{~m}$ higher than today's typical maximum water table elevations (Peterson et al. 2008b). Currently, groundwater level response to changes in river stage is delayed and less pronounced with 
increasing distance inland from the river (DOE-RL 2010). Priest Rapids Dam is operated for electricity generation and surface water storage, which has dramatically reduced the magnitude of river-stage changes on a seasonal basis, but daily and hourly fluctuations have increased.
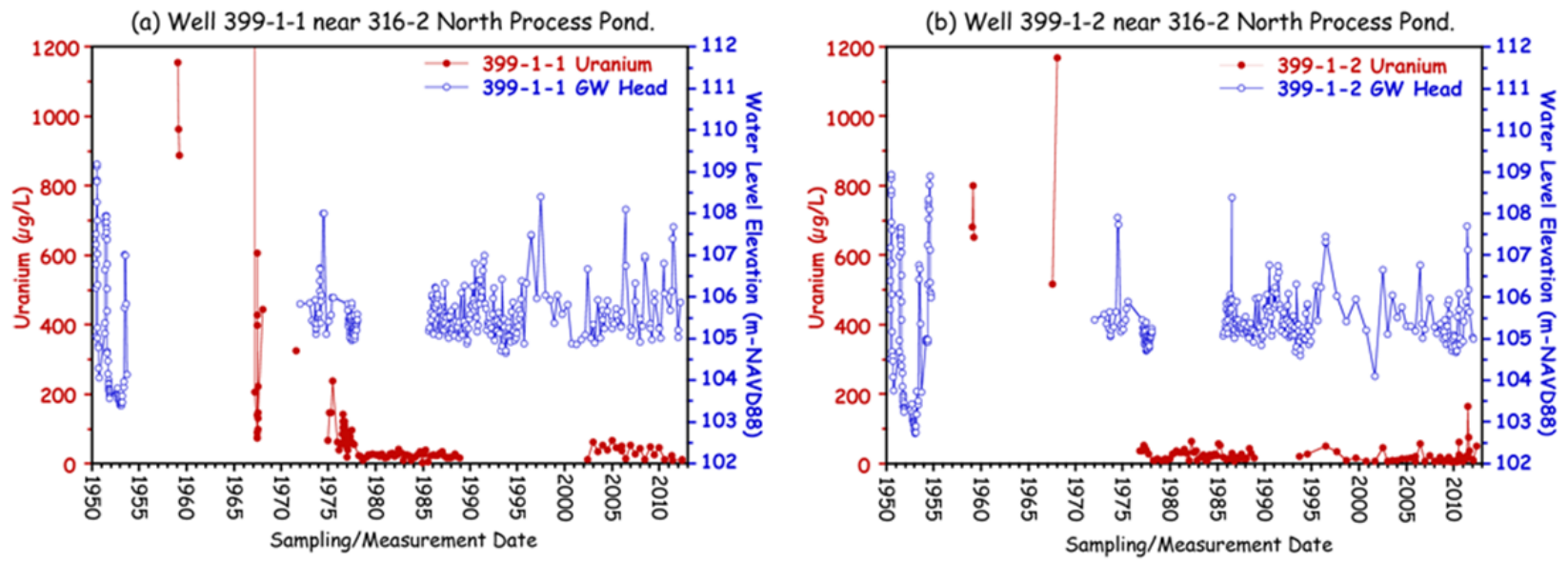

(c) Well 399-2-1 near 316-1 South Process Pond.
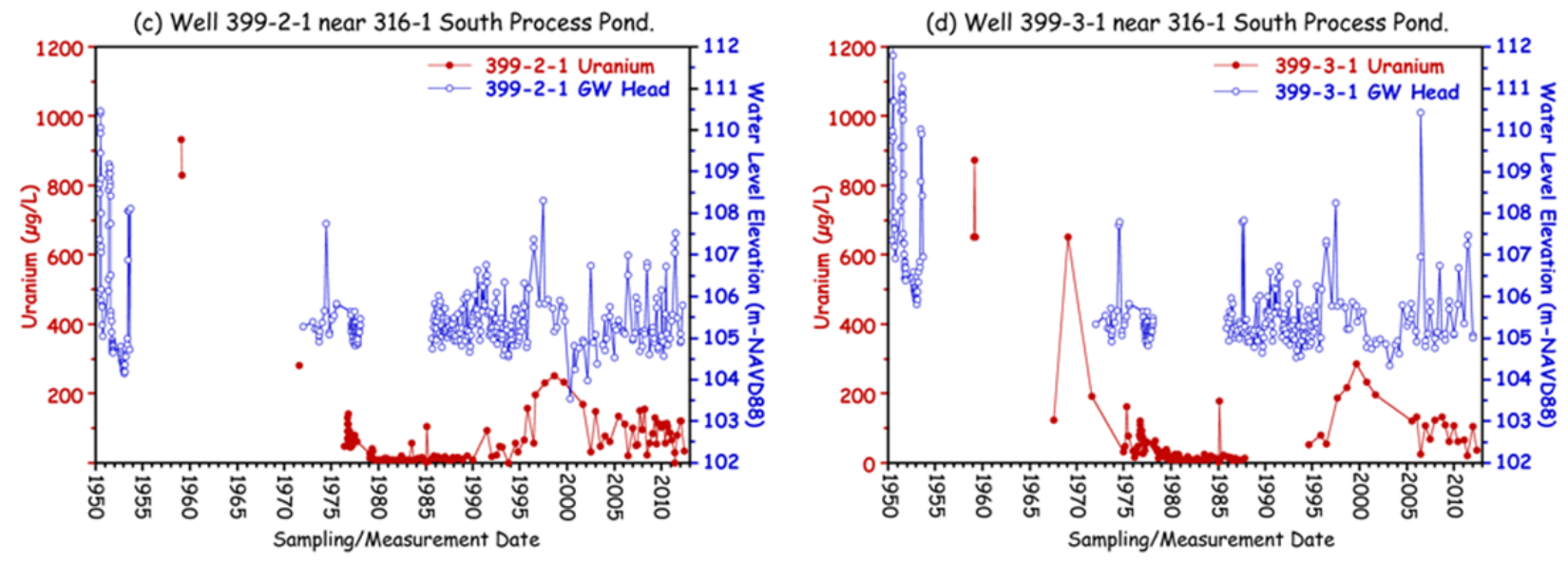

GW Head $=$ Groundwater head measured in well.

2012-DCL-300AreaUCMR-001_09-09

Figure 3.1. Historic uranium and water table trends near the South and North Process Ponds (updated from Petersen et al. 2008 and DOE-RL 2010)

Peterson et al. (2008) also suggested that the historic high groundwater levels (and reversed groundwater flow - away from the river) may have deposited adsorbed uranium in the lower vadose zone (and in areas much broader than the area directly beneath waste sites). Both Haney (1957) and Lindberg and Bond (1979) noted inland movement of the uranium groundwater plume as far west as wells 399-8-1 and 399-8-3 (near Stevens Drive in the city of Richland, Washington). DOE-RL (2010) concluded that intrusion of fresh river water (low in specific conductance) into the unconfined aquifer extended even farther west (at least as far as the 318-7 Burial Ground) than suggested by Lindberg and Bond (1979). Lindberg and Bond (1979) further suggested that changes in specific conductance and temperature may indicate the location of preferential pathways for groundwater flow (Figure 3.2) and that river-water intrusion may occur in these pathways. 


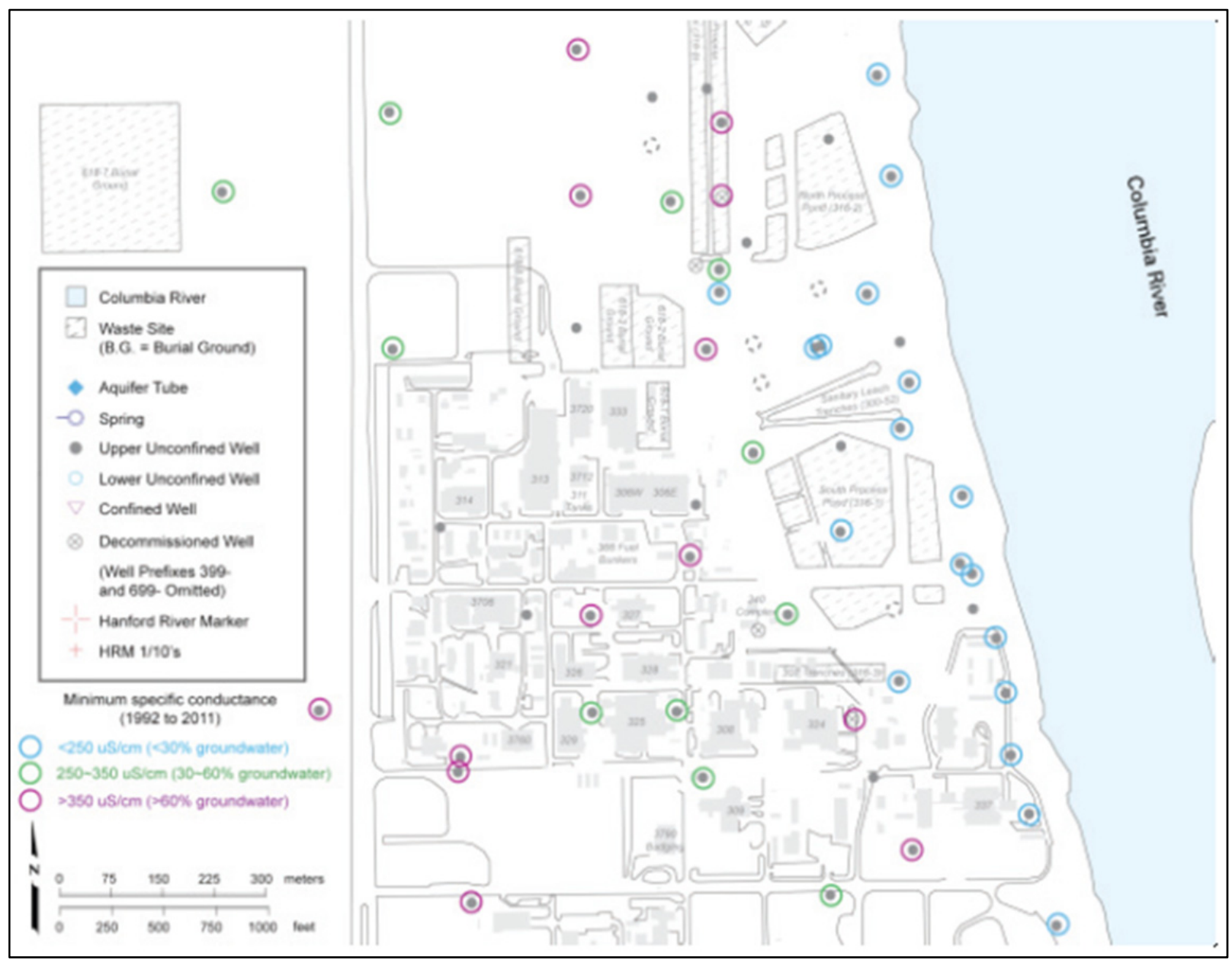

Figure 3.2. Map showing the potential inland extent of river-water intrusion, as indicated by specific conductance fluctuations at monitoring wells and the relationship to the top of the Ringold Formation (modified from DOE-RL 2010)

An analysis of uranium concentrations in well 399-1-17A (Figure 3.3) led Peterson et al. (2008) to suggest that after all wastewater (low bicarbonate) discharges to the Process Trenches (316-5) ended in December 1994, the influx of undiluted (higher bicarbonate) groundwater led to the desorption of uranium and increased flux to groundwater. After the initial influx of uranium, groundwater concentrations decreased gradually as the plume dispersed; frequent concentration spikes were caused by high water table events. Uranium concentrations appear to decrease asymptotically, approaching $50 \mu \mathrm{g} / \mathrm{L}$. A new influx of uranium occurred in early to mid-2006, perhaps in response to a very high water table event. Again, the uranium concentrations appear to decrease rather asymptotically, approaching $75 \mu \mathrm{g} / \mathrm{L}$. In mid-2011, yet another influx of uranium can be observed, again in response to high groundwater (and river) levels, with subsequent decreases in concentrations. Similar but less obvious trends appear in well 399-1-7 (Figure 3.4). Further discussion of trends observed in individual wells is presented in Section 3.3. 


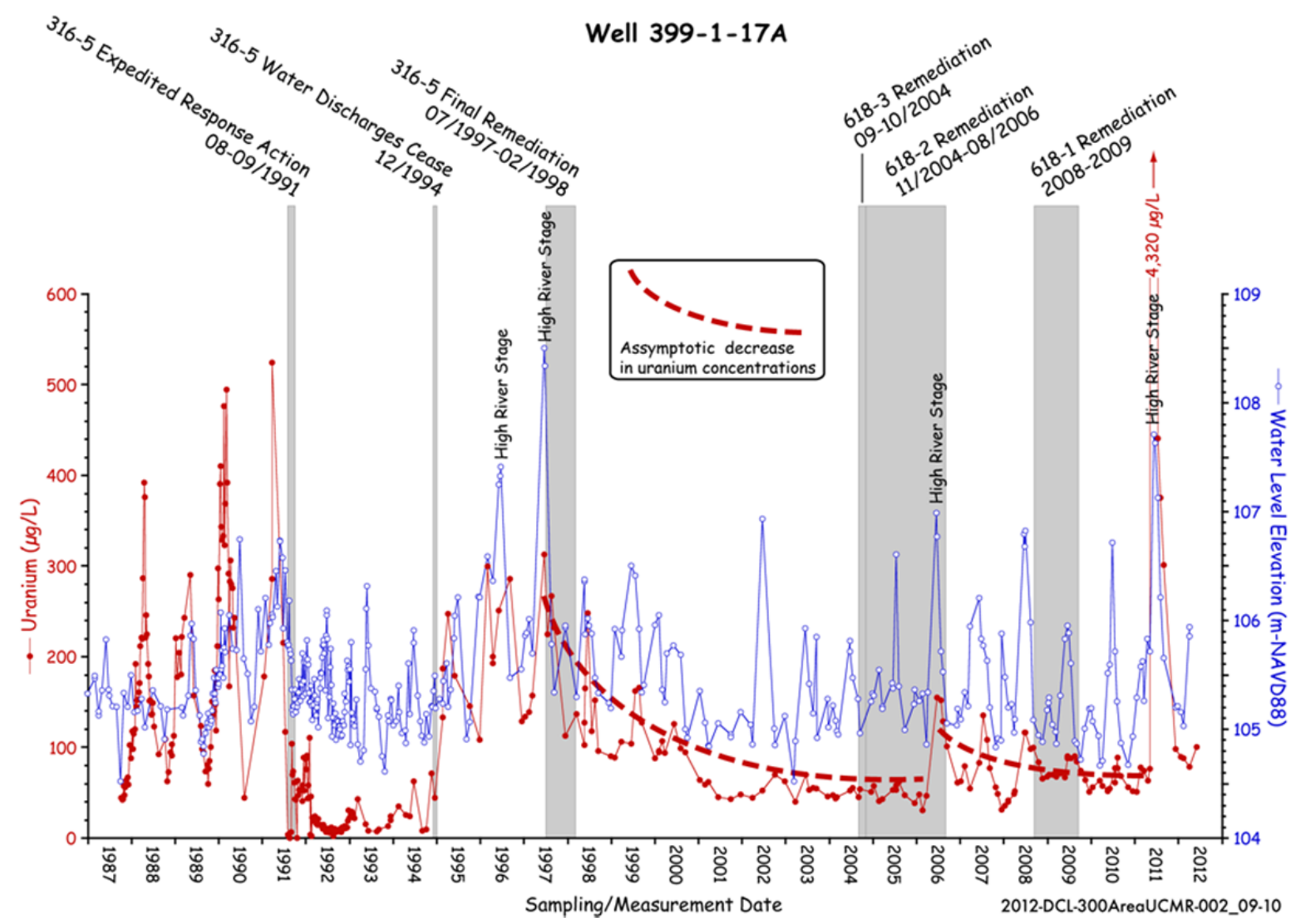

Figure 3.3. Relationship between uranium concentrations and water levels in well 399-1-17A, showing asymptotic decreases in concentrations following an influx of uranium

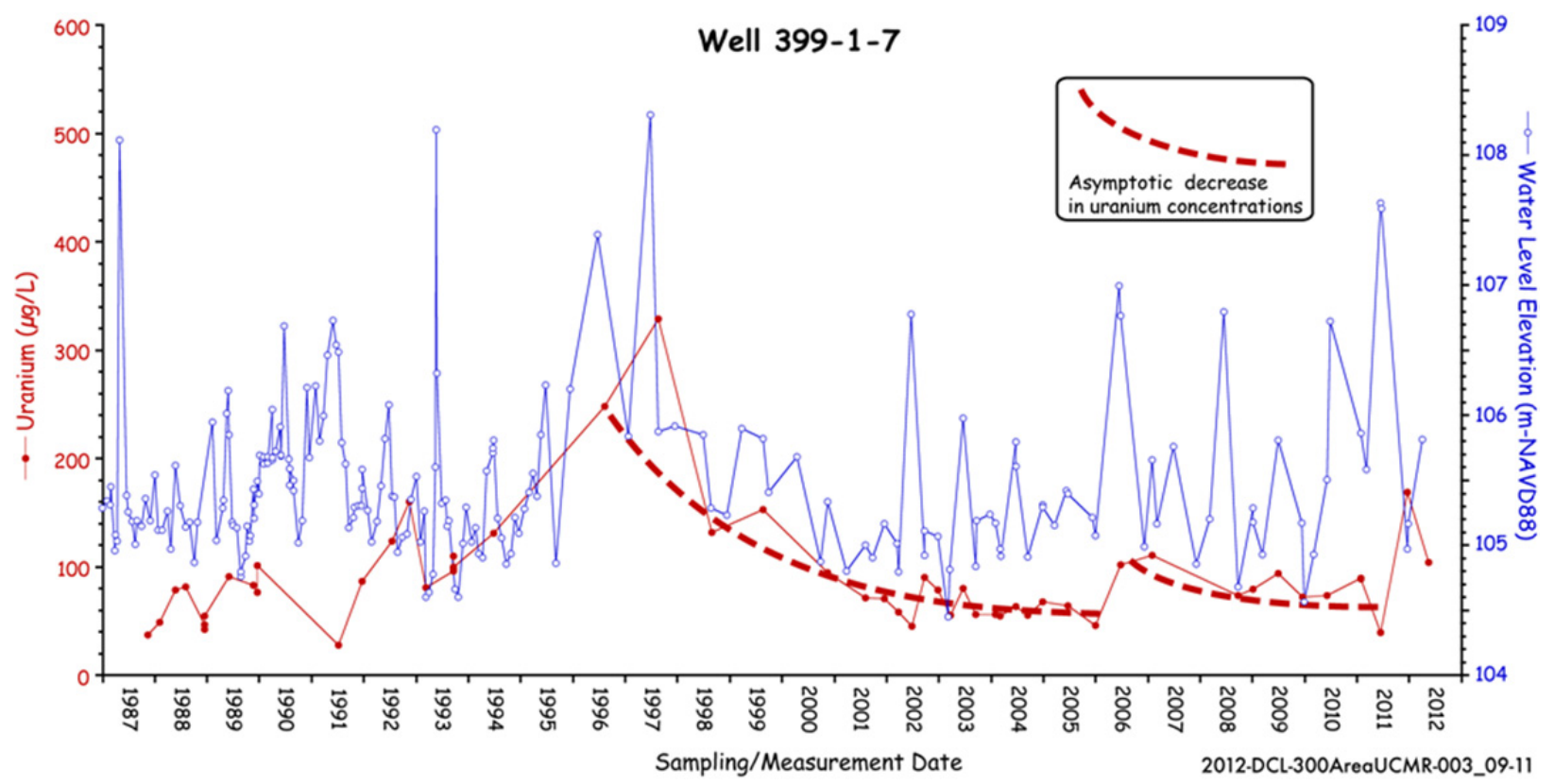

Figure 3.4. Uranium concentration and water-level trends for well 399-1-7 
Peterson et al. (2008) found that high uranium concentrations in wells some distance inland of the river are commonplace and fairly well correlated to high groundwater levels (Figure 3.5), while wells near the river show the opposite (negative) correlation, with uranium concentrations decreasing during high groundwater levels (Figure 3.6). The former is hypothesized to be remobilization of labile uranium held in the lower portion of the vadose zone during high water table conditions, while the latter is explained as a consequence of dilution of groundwater contamination by the intrusion of river water, primarily occurring during periods of high river stage/water table conditions (Zachara et al. 2005; Petersen et al. 2008). The positive correlation is far from absolute, but groundwater elevations near $107 \mathrm{~m}$ generally cause mobilization. Comprehensive multiyear sampling of IFRC wells before, during, and after the spring water table rise has revealed complex behaviors resulting from the impacts of multiple factors (Section 4). Thus, simple cause-and-effect explanations for well concentration trends should be viewed with caution.
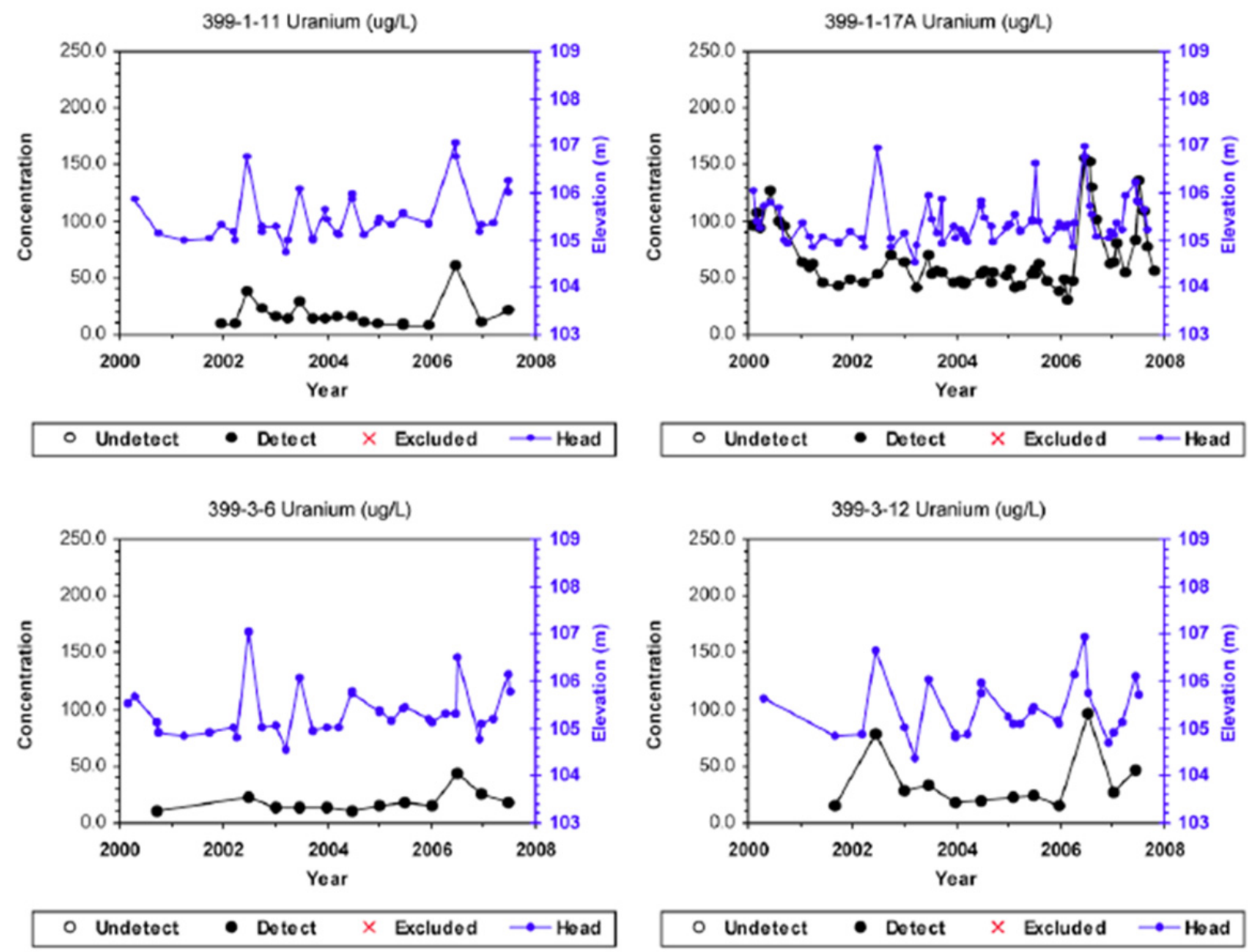

Figure 3.5. Wells showing increased uranium concentrations when water level is raised (updated from Peterson et al. 2008b) 

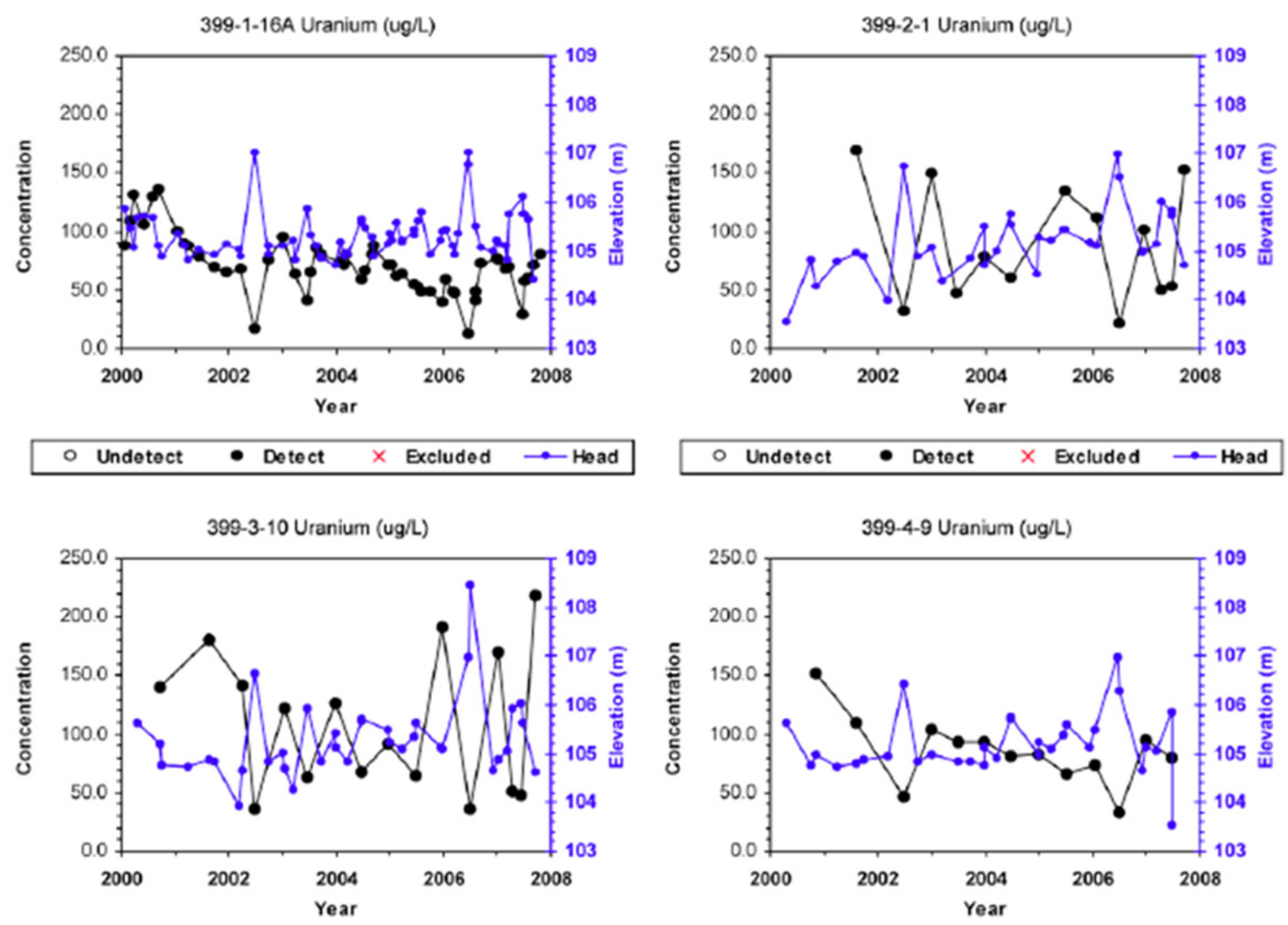

○ Undetect $\bullet$ Detect $\times$ Excluded $\multimap$ Head

$\circ$ Undetect $\bullet$ Detect $\times$ Excluded $\longrightarrow$ Hoad

Figure 3.6. Wells showing decreased uranium concentrations when water level is raised (updated from Peterson et al. 2008b)

A review of monitoring results for the entire 300 Area is summarized in a map showing where the correlation between water table elevation and uranium concentrations is positive or negative (Figure 3.7). Where more frequent (monthly or shorter) groundwater monitoring results are available, a time lag may be seen between when the water table is highest and when the highest uranium concentrations are measured (Figure 3.8). Well 399-1-17A is believed to be located near a secondary source for mobile uranium in the lower portion of the vadose zone. A delay of approximately 50 days between the highest water level and the subsequent maximum uranium concentration is indicated for recent events. Similar lag times are observed at well 399-1-21A. However, at other locations, lag times vary and may not only reflect differences in source location, but also differences due to hydraulic conditions such as vertical borehole flow and well configurations (e.g., screen length). Additional discussions of this topic are provided in Section 4. 


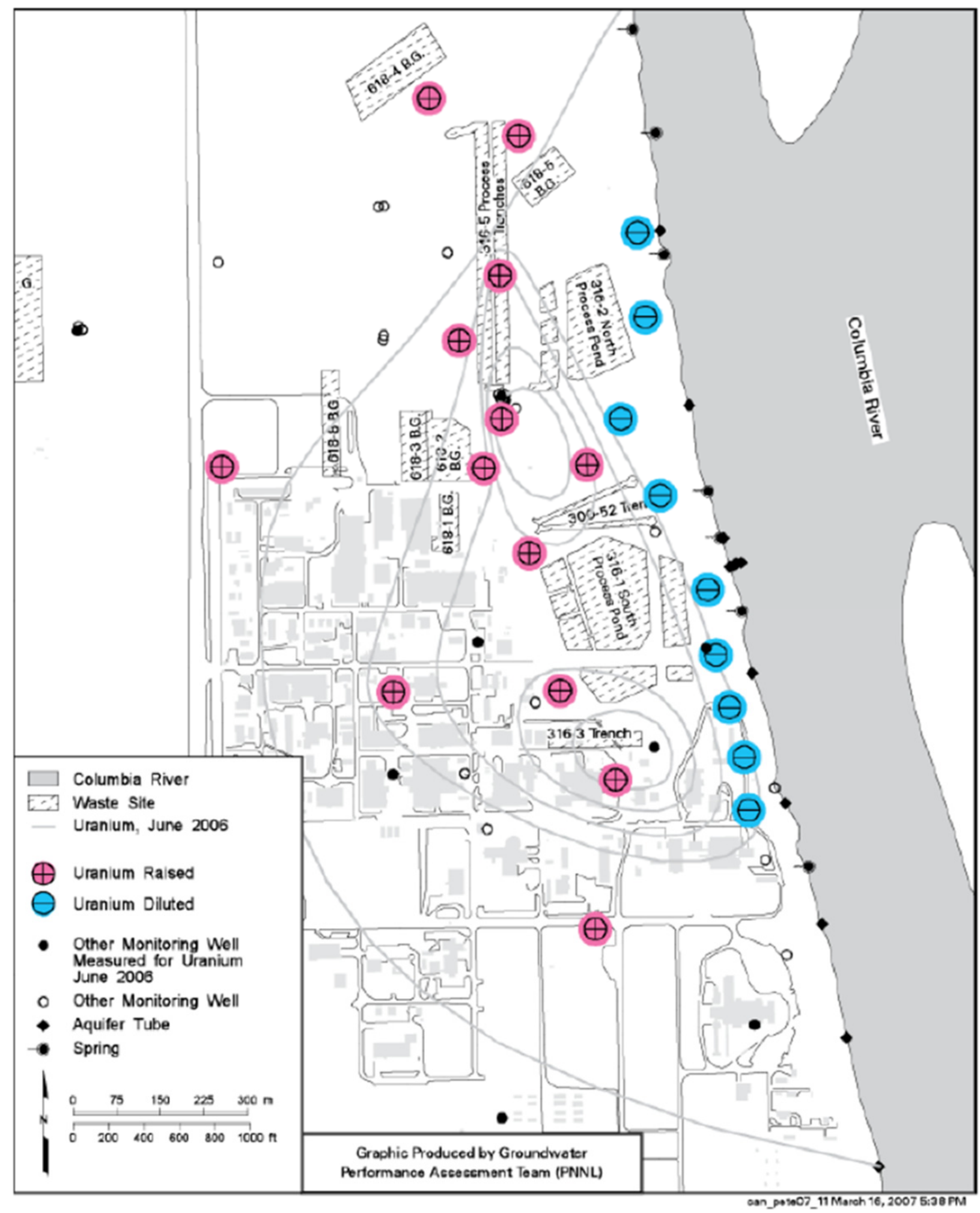

Figure 3.7. Map illustrating areas where uranium concentrations vary in response to raised water levels at the well (modified after Peterson et al. 2008b to show relationship to top of Ringold) 

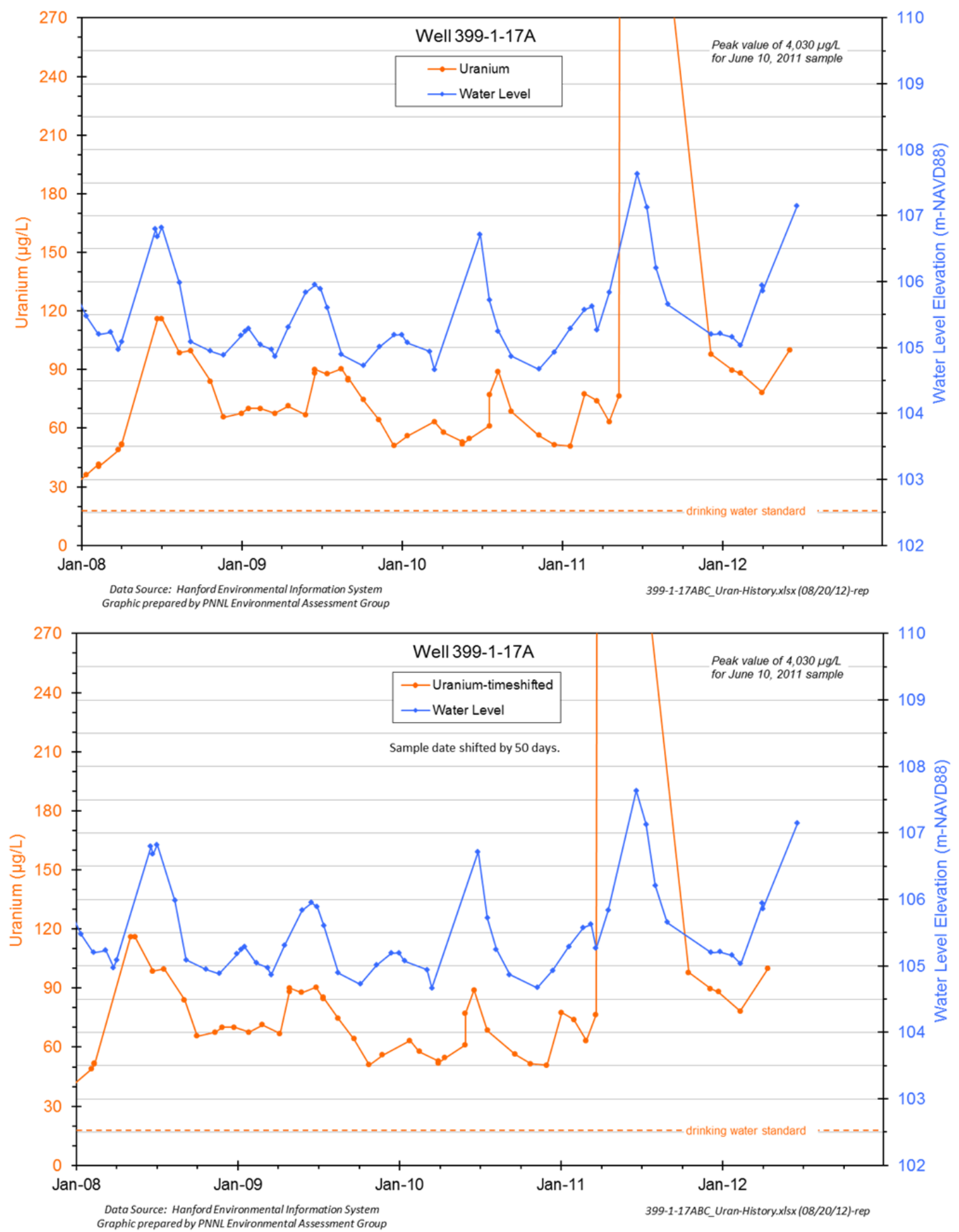

Figure 3.8. Time lag between highest water level at well 399-1-17A and highest subsequent uranium concentration in groundwater 
Maximum observed uranium concentrations are found at groundwater monitoring wells whose screens monitor the upper portion of the unconfined aquifer within the saturated Hanford formation. At the IFRC site, the highest concentrations are generally found near the top of the aquifer and lowest concentrations deeper in the aquifer, with intermediate concentrations in between. These conditions may change both seasonally and annually (Section 4). Vertical flow in wellbores at the IFRC site creates decreased uranium concentrations during periods of upward flow (i.e., from low concentrations to higher concentrations) and increased uranium concentrations during periods of downward flow (i.e., from higher concentrations to lower concentrations [Vermeul et al. 2011]). IFRC wells were not uniform in their vertical flow behaviors; at any given time, some wells were flowing upward while others were flowing downward, posing significant difficulty in the interpretation of monitoring data. The vertical distribution of uranium measured in aquifer tubes near the river does not show a consistent pattern. In general, the vertical distribution of uranium within the unconfined aquifer and the effects of vertical borehole flow are not well understood throughout the 300 Area.

\subsection{Uranium Concentration Trends Relative to Significant Events and Source Areas}

Individual monitoring wells have shown increased uranium concentrations from specific events including changes in waste disposal operations, waste site remediation, and changes in groundwater levels and groundwater composition. These changes are tied to source zones activated during different time periods including the following: 1) the 300 Area Process Trenches and 307 Process Trench; 2) the 618-5 Burial Ground; 3) the 618-2 Burial Ground; and 4) the 618-7 Burial Ground.

\subsubsection{Area Process Trenches and 307 Process Trench}

An expedited response action was performed in 1991 to excavate contaminated sediments from the

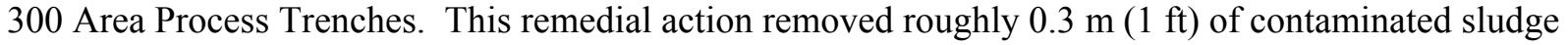
and soil from the trench walls, and $1.3 \mathrm{~m}$ (4 ft) of contaminated sludge and soil from the trench bottoms over the southern two-thirds of the trenches (DOE-RL 1992, 2010). The soil was watered prior to and during excavation to minimize dust generation.

After the expedited response action, the trenches continued to receive nonregulated liquid effluent until they were taken out of service in December 1994. In early 1995, uranium concentrations began to rise in monitoring well 399-1-17A (Figure 3.3) as fresh groundwater (higher in ionic strength) migrated into the area, replacing previously discharged low ionic strength water and promoting desorption of the uranium off aquifer sediments (Peterson et al. 2008b). In April 1995, uranium concentrations peaked to pre-expedited response action levels $(247 \mu \mathrm{g} / \mathrm{L}$, April 5, 1995). Uranium concentrations then decreased until March 1996 when uranium concentrations increased as groundwater rose in response to high river levels (Figure 3.9). Through June 1996, groundwater levels remained high, and in September, uranium concentrations peaked at $286 \mu \mathrm{g} / \mathrm{L}$ on September 3, 1996 (Figure 3.3). Uranium concentrations decreased until spring 1997, when they again began to rise in response to high groundwater levels caused by high river stage. Peterson et al. (2008) attributed the increased uranium to remobilization of uranium from the lower vadose zone near liquid disposal sites during the 1996-1997 period of unusually high water table conditions. These high uranium concentrations moved east-southeast toward the river by late summer 1997 (Figure 3.10), and then spread out along the river (Figure 3.11 and Figure 3.12). 


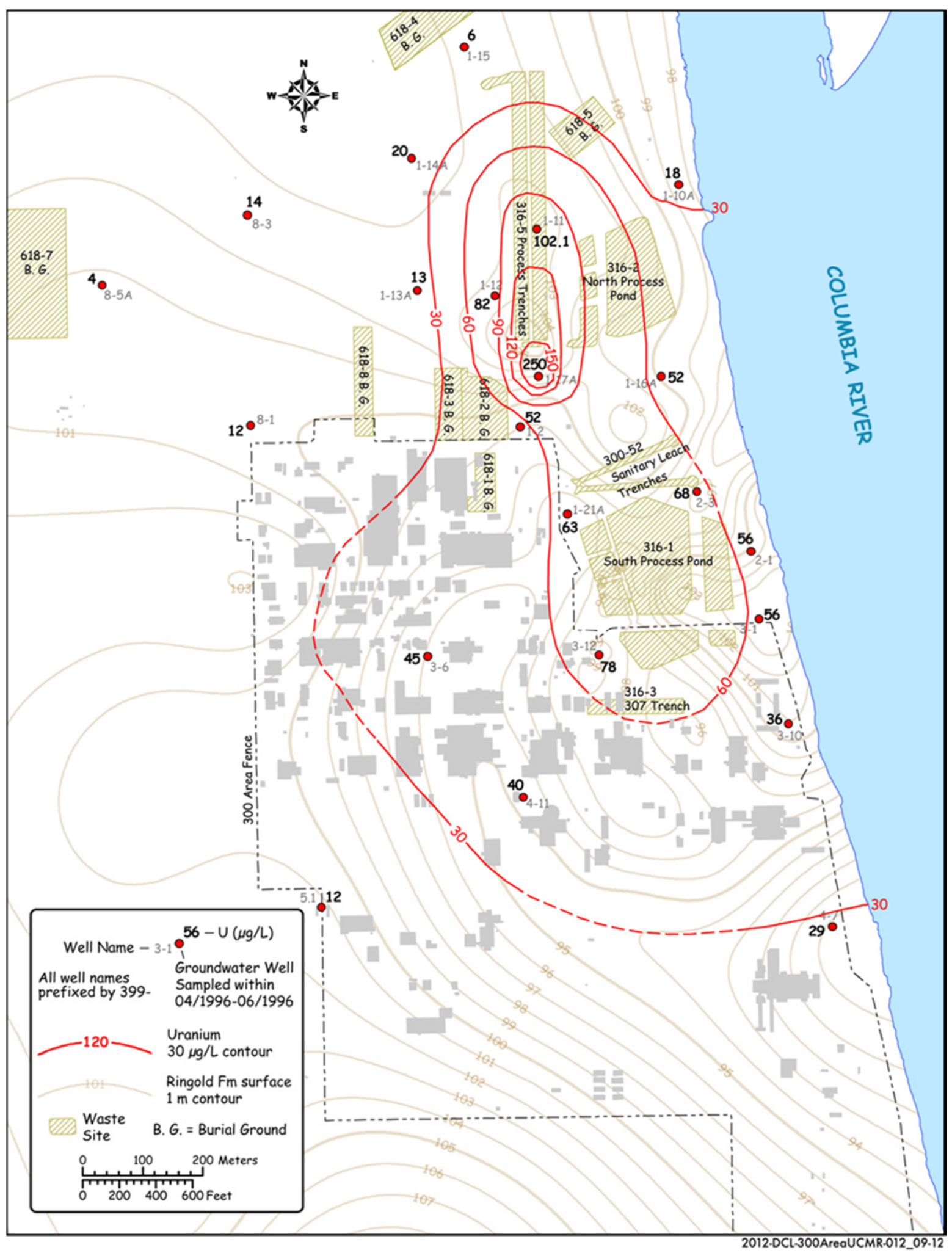

Figure 3.9. Maximum uranium concentrations in groundwater during April-June 1996 (when water levels were high) 


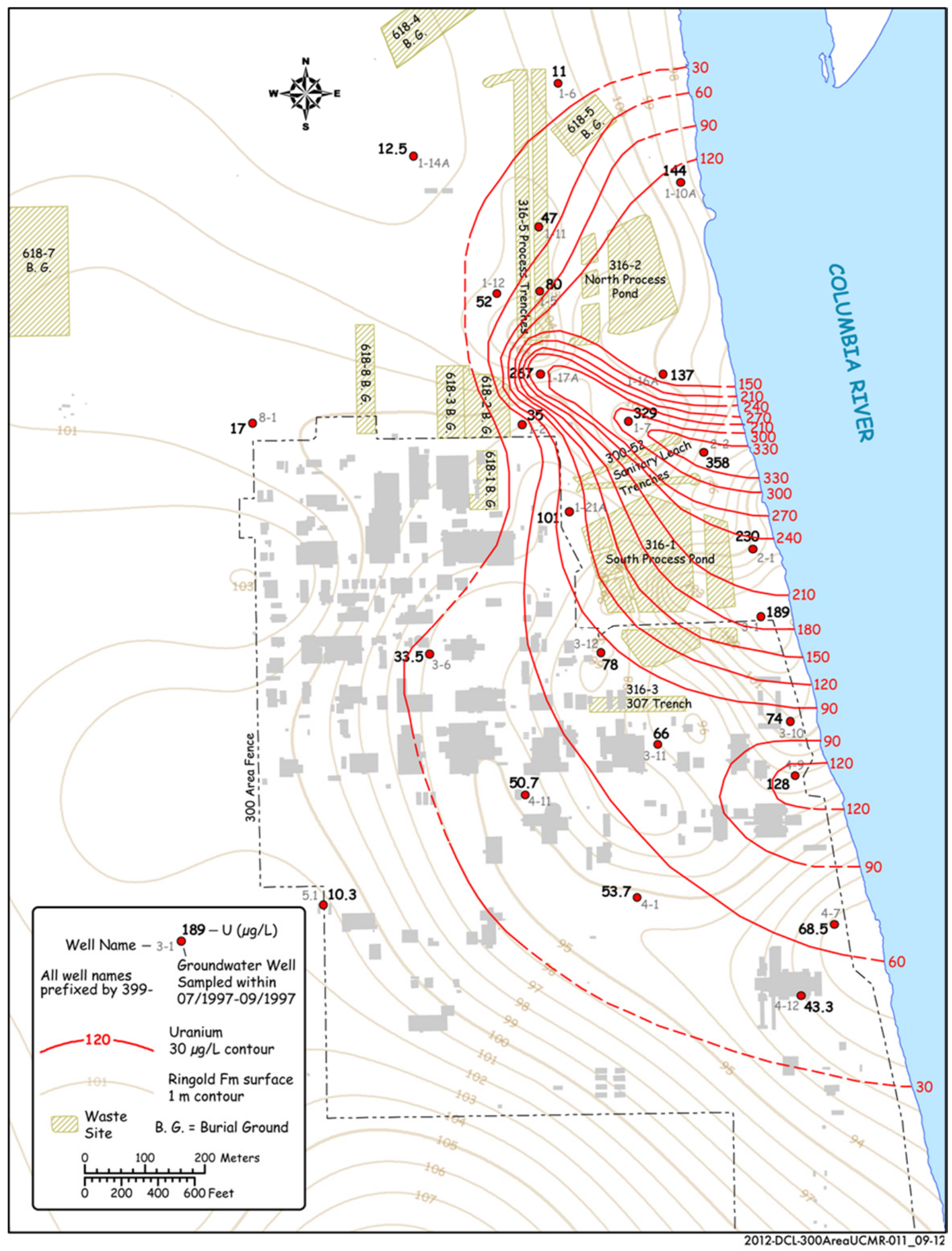

Figure 3.10. Maximum uranium concentrations in groundwater during July-September 1997 


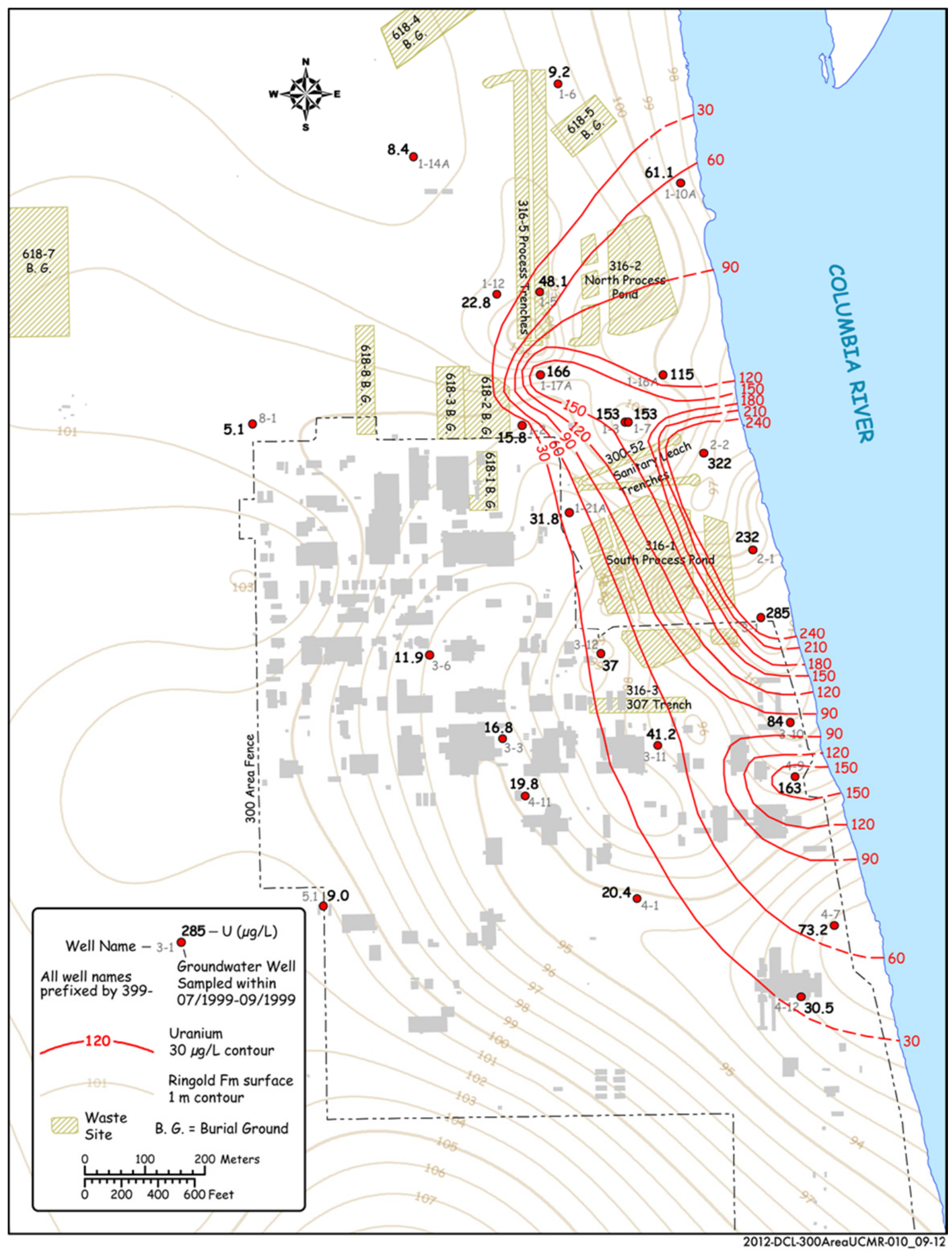

Figure 3.11. Maximum uranium concentrations in groundwater during July-September 1999 


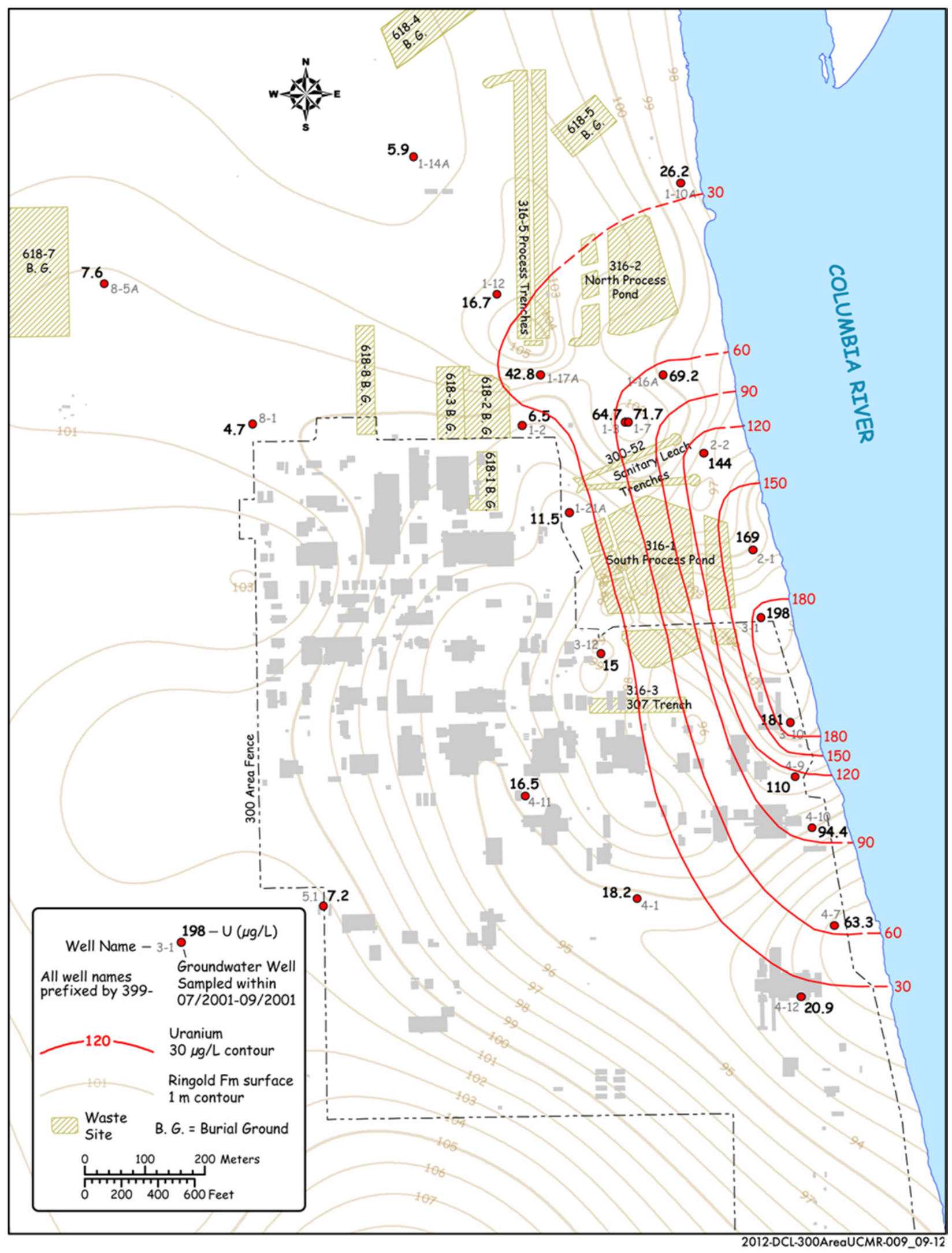

Figure 3.12. Maximum uranium concentrations in groundwater during July-September 2001 
Between July 1997 and February 1998 (WIDS General Summary Report dated February 24, 2012), the spoils area, the process trenches, and 16 related unplanned release sites were remediated under an integrated Resource Conservation and Recovery Act (RCRA)/CERCLA process. The maximum excavation depth was $5.5 \mathrm{~m}$ (18 ft) bgs (DOE-RL 2010). This resulted in the site being closed through RCRA and CERCLA regulations. Uranium concentrations in groundwater remained high during the remediation in spite of lower groundwater levels, most likely in response to increased recharge from dust suppression water and removal of soil cover during the rainy season. Uranium concentrations peaked in June 1998, following high groundwater levels in May and June.

The influx of uranium, especially during the 1996 and 1997 time frame, is observed in groundwater adjacent to the southern portion of the Process Trenches (Figure 3.8). Subsequent dispersion and migration of this contamination can be seen in downgradient wells. Wells near the Process Trenches show sharp peaks during 1996 and 1997, followed by an asymptotic decrease in concentrations over the next 10 years until 2006. Wells further downgradient and towards the river, show a smoothed peak occurring 2 to 3 years later. The spatial distribution and timing of peak uranium concentrations from 1995 to 1997 suggest both primary (remediation) and secondary sources of uranium near the south end of the Process Trenches and/or the process sewer (Figure 3.9).

Peterson et al. (2008) noted elevated uranium concentrations in monitoring wells near former liquid waste disposal sites during the summers of 2006 and 2007, when the water table rose above long-term levels. Increases in dissolved uranium were observed in wells outside of the footprints of the former liquid-water disposal sites. Perhaps these uranium increases resulted from the remobilization of sorbed uranium from past, high-concentration groundwater plumes. Figure 3.13 illustrates the spatial distribution of wells showing increased uranium concentrations commensurate with unusually high groundwater levels, and the trends in uranium concentrations with time.

High frequency (every 6 hours) river-stage data from the 300 Area (Figure 3.14) indicate that high river stage occurred between mid-April and the end of June 2006, with the highest river stage occurring between late-May and the end of June 2006. High frequency groundwater level data are not available for this time frame; however, where monthly water-level data are available, the water-level changes correlate well with the river-stage data. Away from the river, the high groundwater levels correlate with increased uranium concentrations at wells 399-1-17A, 1-11, 1-12, and 1-7, near the south end of the Process Trenches, the process sewer distribution lines, and other potential primary source areas (e.g., the 618-1, -2 , and -3 Burial Grounds).

Uranium concentrations increased dramatically beneath the south end of the Process Trenches during the spring 2011, reaching a maximum concentration of $4030 \mu \mathrm{g} / \mathrm{L}$ in well 399-1-17A on June 10, 2011, and $302 \mu \mathrm{g} / \mathrm{L}$ in well 399-1-11 on June 14, 2011 (Figure 3.15). River discharges from Priest Rapids Dam during this time were higher (exceeding 175,000 cubic feet per second [cfs]) and occurred over a longer duration (2.5 months) than in the previous five seasons (Figure 3.14). A region of elevated uranium concentrations can also be seen in the vicinity of the eastern portion of the South Process Pond and the 307 Disposal Trenches, while relatively low concentrations are seen along the river, attributed to the influx of river water (Figure 3.15). 


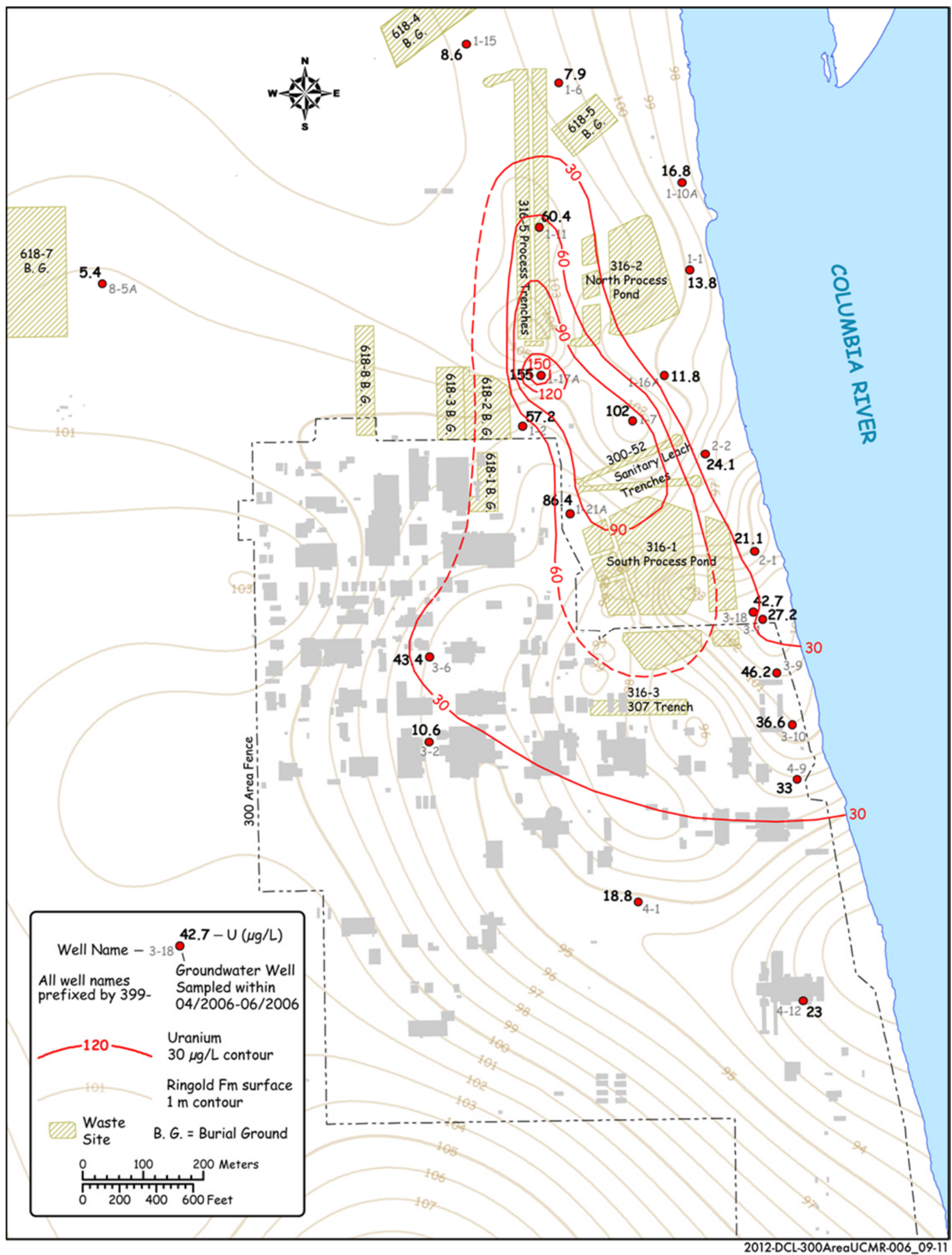

Figure 3.13. Maximum uranium concentrations in groundwater during April-June 2006 (when water levels were high) 


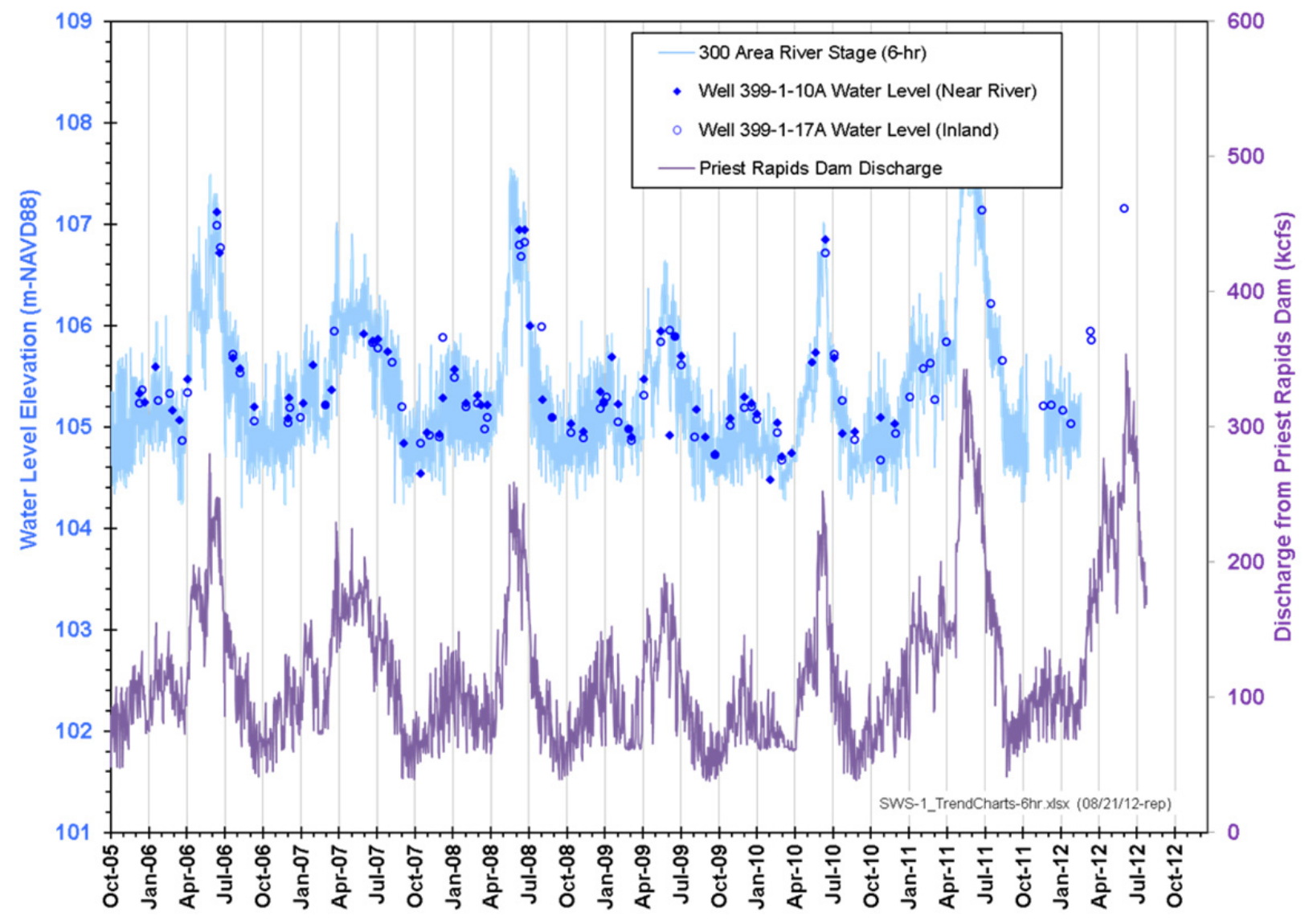

Figure 3.14. Relationship between river discharge, river stage, and groundwater levels at wells 399-1-10A and 399-1-17A

A similar pattern of elevated uranium concentrations was also observed during spring 2012 (Figure 3.16), in response to abnormally high river stage and groundwater levels over a long (3.5 months) period. Monitoring data show the presence of high uranium concentrations (over $500 \mu \mathrm{g} / \mathrm{L}$ in well 399-1-55) beneath the North Process Pond, as well as in the vicinity of the south end of the Process Trenches and the 307 Trenches.

Similar to the 1996 and 1997, as well as the 2006 and 2007 high-water years, the increased uranium concentrations are attributed to remobilization of uranium underlying primary source areas (e.g., 307 Trenches and the 300 Area Process Trenches), as well as residual uranium from past groundwater plumes that had been left stranded after the period of high volume discharges in the 1943 to 1975 time frame. 


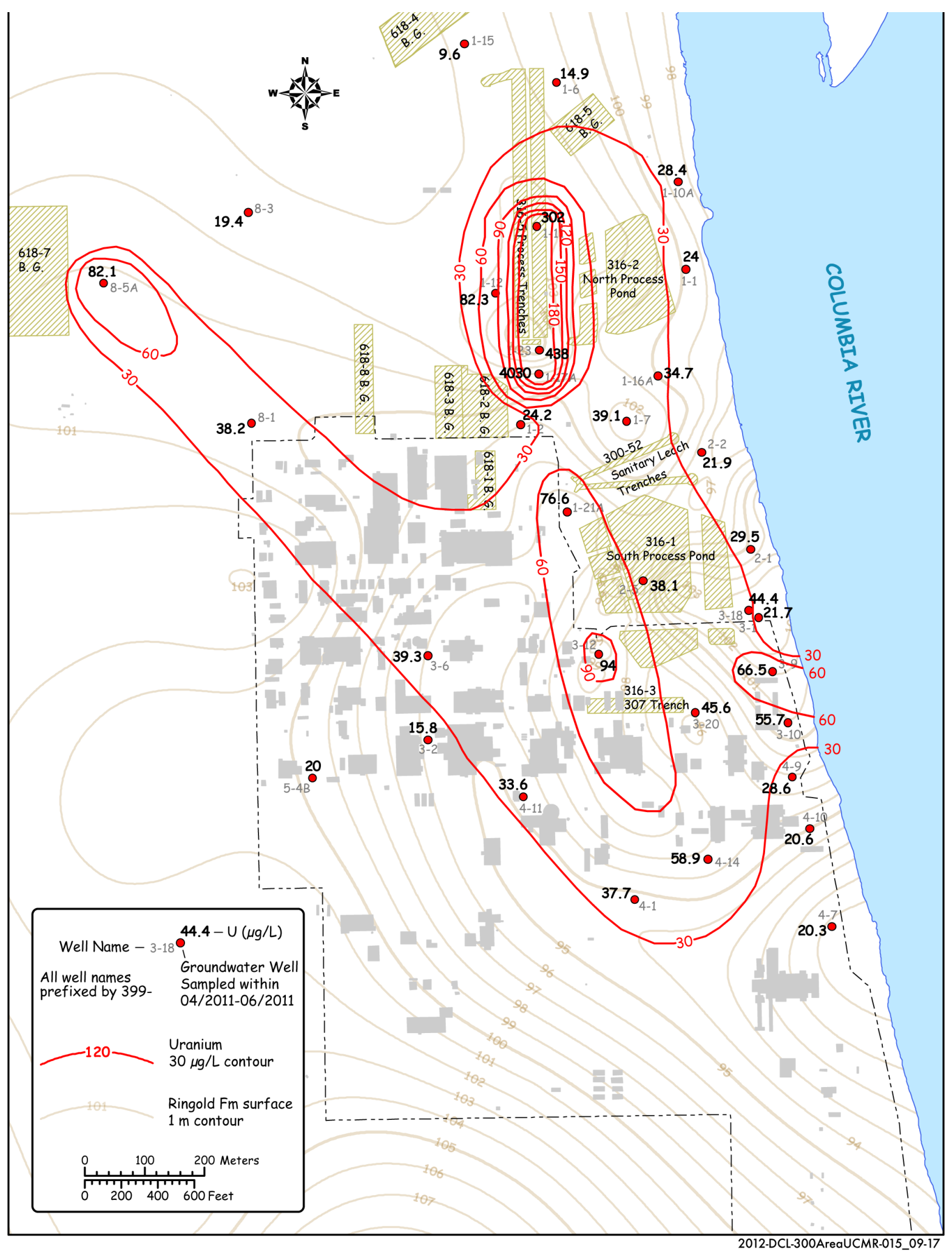

Figure 3.15. Maximum uranium concentrations in groundwater from April to June 2011 (during high water levels) 


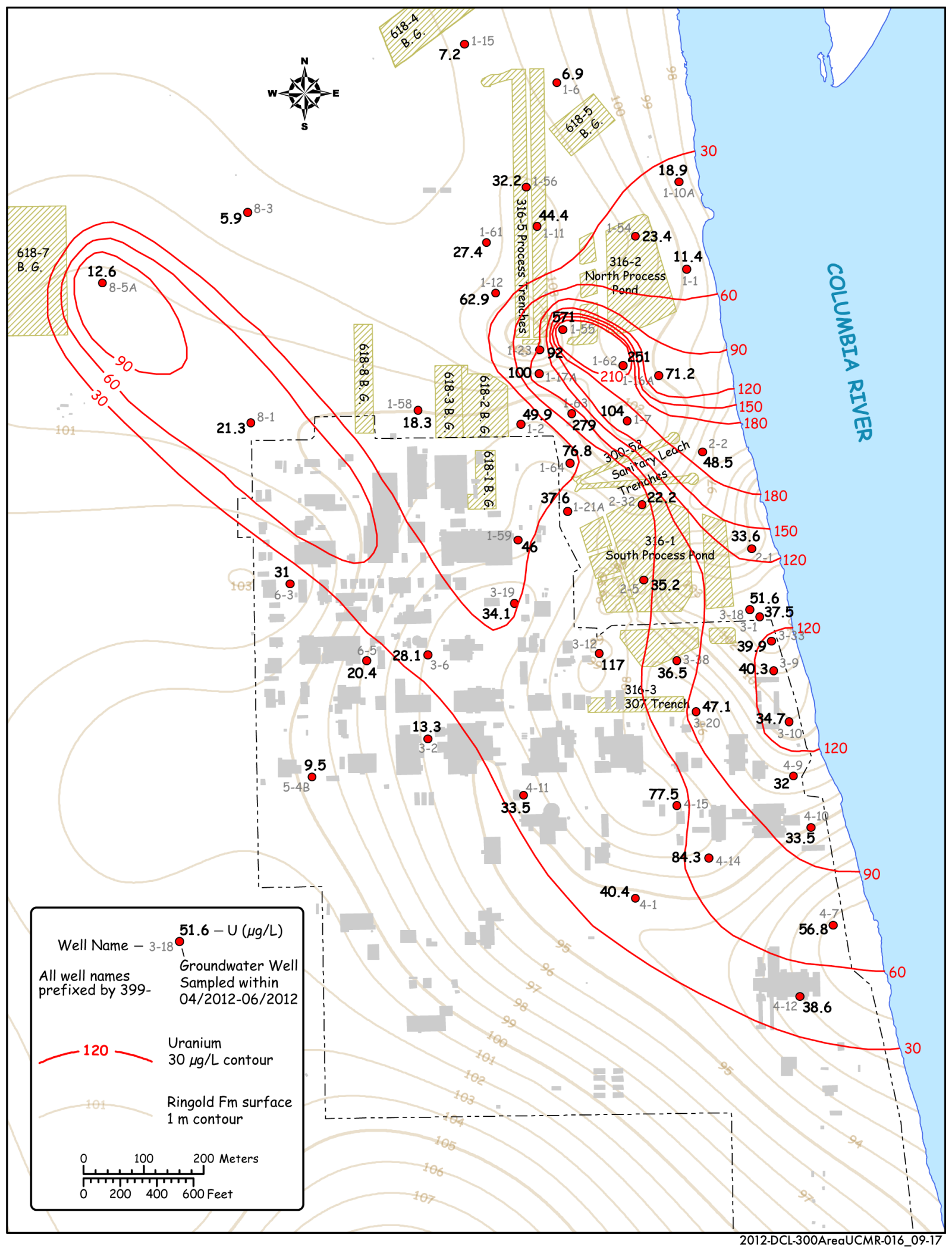

Figure 3.16. Maximum uranium concentrations in groundwater during April-June 2012 (during high water levels) 


\subsubsection{8-5 Burial Ground}

The 618-5 Burial Ground and burn pit received uranium-bearing trash from the 300 Area between 1945 and 1962 (DOE-RL 2010). The 618-5 Burial Ground was excavated between October 2002 and March 2003 (CVP-2003-00021) to a maximum excavation depth of $7.5 \mathrm{~m}(24.6 \mathrm{ft})$.

Uranium concentration trends for well 399-1-10A (160 m southeast of the burial ground) show a marked increase in uranium in the fall of 2002 (Figure 3.17). Prior to remediation, uranium concentrations were 13 to $32 \mu \mathrm{g} / \mathrm{L}$. However, during remediation, concentrations increased to 178 to $235 \mu \mathrm{g} / \mathrm{L}$. After remediation and during elevated spring river-stage conditions, uranium concentrations decreased to a low of 64-72 $\mu \mathrm{g} / \mathrm{L}$. Ambient groundwater with higher bicarbonate returned after riverstage decrease, both carrying and desorbing sediment-bound uranium. After temporary dilution and a secondary peak, uranium concentrations decreased asymptotically, reaching $20 \mu \mathrm{g} / \mathrm{L}$ in the spring of 2006.

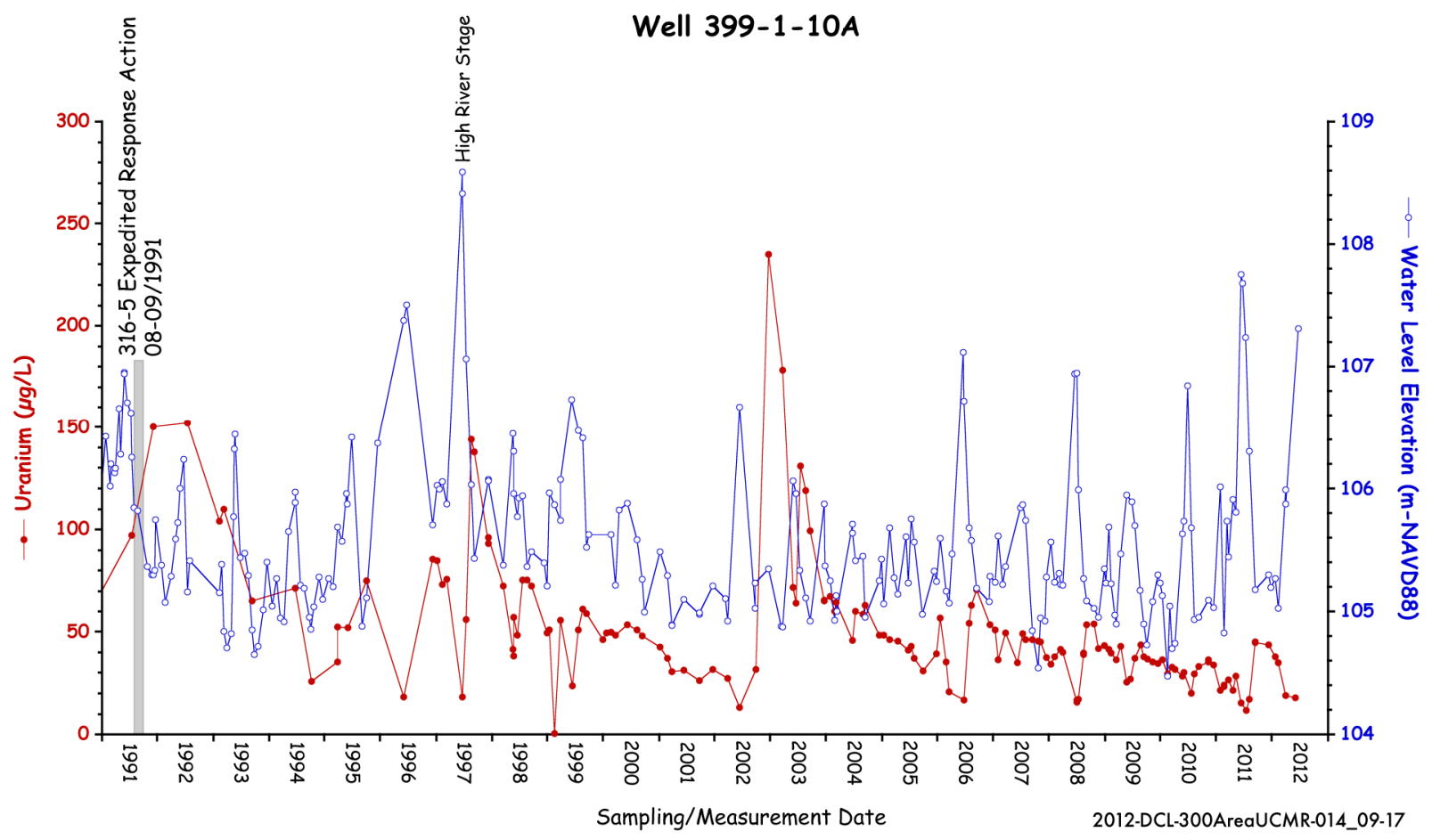

Figure 3.17. Uranium concentrations in monitoring well 399-1-10A downgradient of the 300 Area Process Trenches and the 618-5 Burial Ground

Well 399-1-10A is the only monitoring well showing the influx of uranium during 2002 and 2003. The timing of this influx is consistent with releases from the 618-5 Burial Ground during remediation activities. Figure 3.18 and Figure 3.19 show the appearance of elevated uranium concentrations southeast of the 618-5 Burial Ground. 


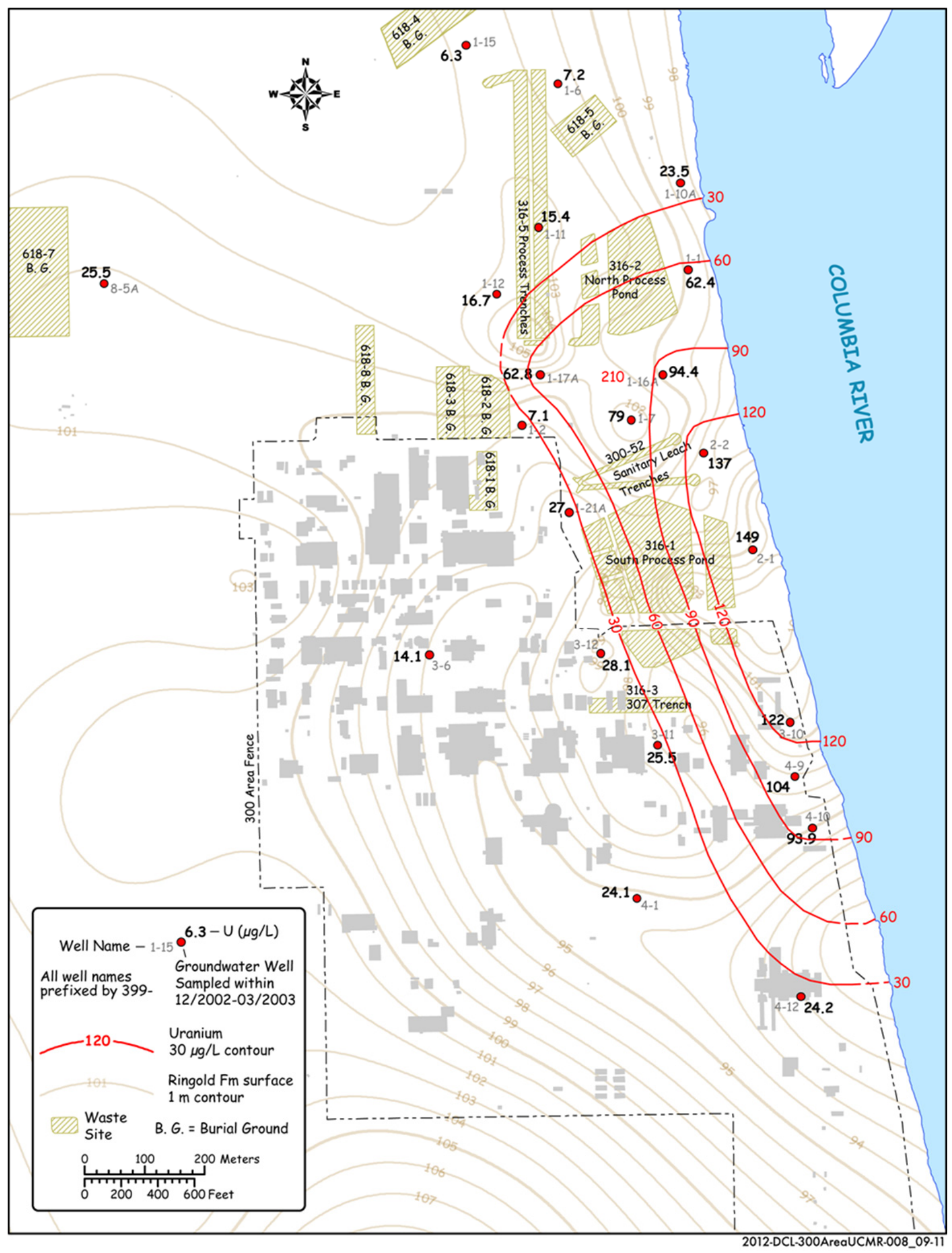

Figure 3.18. Maximum uranium concentrations in groundwater from December 2002-March 2003 


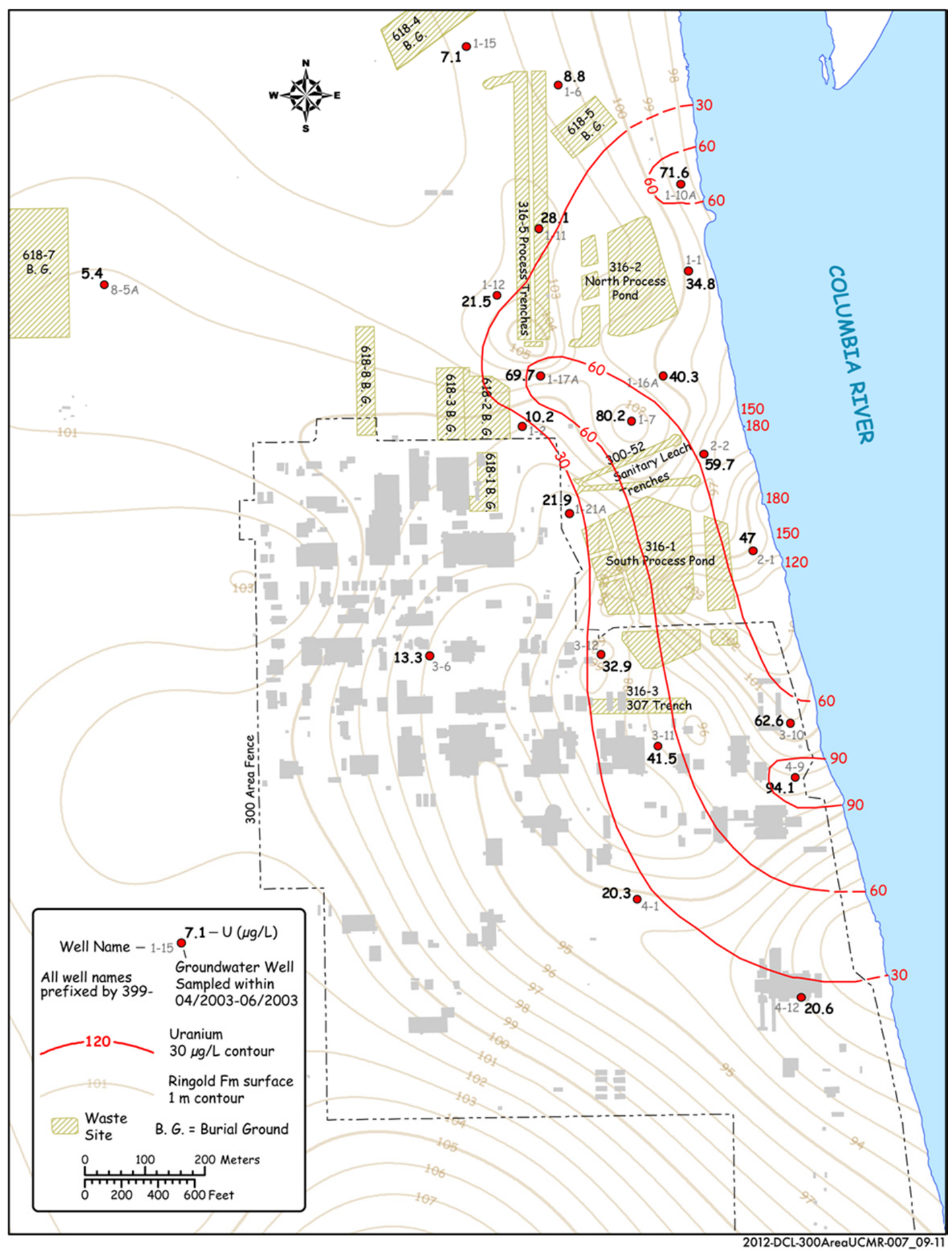

Figure 3.19. Maximum uranium concentrations in groundwater from April-June 2003 


\subsubsection{8-2 Burial Ground}

Excavation of the 618-2 Burial Ground was conducted between November 2004 and August 2006 (with a hiatus throughout 2005) (CVP-2006-00010). (Note that DOE-RL [2010] states: "Remediation of the 618-2 Burial Ground began in August 1996 and was completed in November 2004.") A single peak in uranium concentrations (up to $57.2 \mu \mathrm{g} / \mathrm{L}$ on June 23, 2006) was measured in well 399-1-2 (Figure 3.13). However, near the Columbia River, increased water levels are often correlated with decreased uranium concentrations due to the influx of fresh river water. This makes it difficult to track the migration of increased uranium concentrations from well 399-1-2 towards the river.

\subsubsection{8-7 Burial Ground}

The 618-7 Burial Ground received contaminated equipment and material (including hundreds of 114- L (30-gal) drums of Zircaloy chips contaminated with moderate amounts of beryllium and uranium) from the 300 Area facilities. Remedial activities for the 618-7 Burial Ground were conducted from January 4, 2008 through November 15, 2008 (CVP-2008-00002; DOE-RL 2010).

A groundwater plume (consisting primarily of uranium) developed near the former 618-7 Burial Ground because of excavation and backfilling during remedial activities (DOE-RL 2010). High uranium concentrations were first observed in January 2008 (Figure 3.20), along with increased concentrations of chromium and constituents associated with soil fixative material (calcium and chloride). This was attributed to infiltration of dust-control water and soil fixatives during remedial actions.

Uranium concentrations reached a maximum of $225 \mu \mathrm{g} / \mathrm{L}$ in well 399-8-5A on September 26, 2008 (Figure 3.21). On November 21, 2008, a peak concentration of $108 \mu \mathrm{g} / \mathrm{L}$ was observed in well 399-8-1 (340 m southeast of 399-8-5A, Figure 3.22). This time difference in the peak concentrations between the two wells suggests a migration velocity of about $6 \mathrm{~m} / \mathrm{d}$.

A secondary maximum $(211 \mu \mathrm{g} / \mathrm{L})$ was observed in well 399-8-5A on July 7, 2009. Concentrations in well 399-3-6 (480 m southeast of well 399-8-1) reached a maximum of $81.2 \mu \mathrm{g} / \mathrm{L}$ on August 10, 2011, suggesting a migration velocity of about $0.5 \mathrm{~m} / \mathrm{d}$.

DOE-RL (2010) stated that the contaminant plume originating from remediation of the 618-7 Burial Ground was likely to disperse significantly before reaching the Columbia River. Figure 3.23 illustrates the uranium plume during the winter of 2011 and 2012 and shows the contamination plume from the burial ground had dispersed.

\subsection{Trends in Uranium Plume Parameters}

Several previous attempts have been made to determine whether a trend exists in the level of contamination in the 300 Area, indicated by estimates of plume parameters, including 1) areal extent of the mapped plume, 2) volume of contaminated groundwater, and 3) mass of dissolved uranium contained in the plume (Peterson et al. 2008b). The plume parameter estimates were made using data from months that approximate the possible range in parameters (June and December) representing high and low riverstage conditions. The previous calculation results indicated the three plume parameters mentioned above remained relatively constant during the period from 2002 to 2007. 


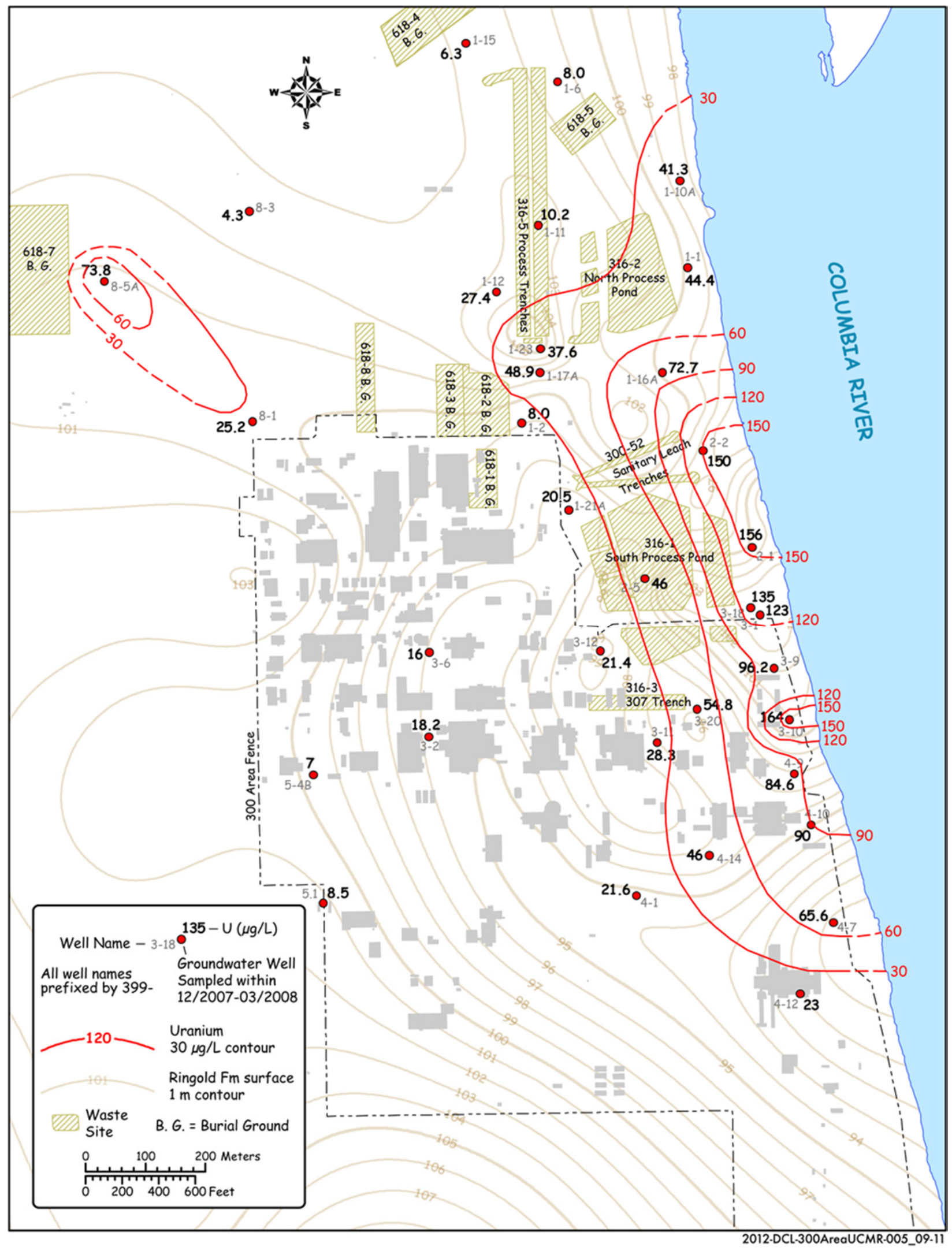

Figure 3.20. Maximum uranium concentrations in groundwater from December 2007-March 2008 


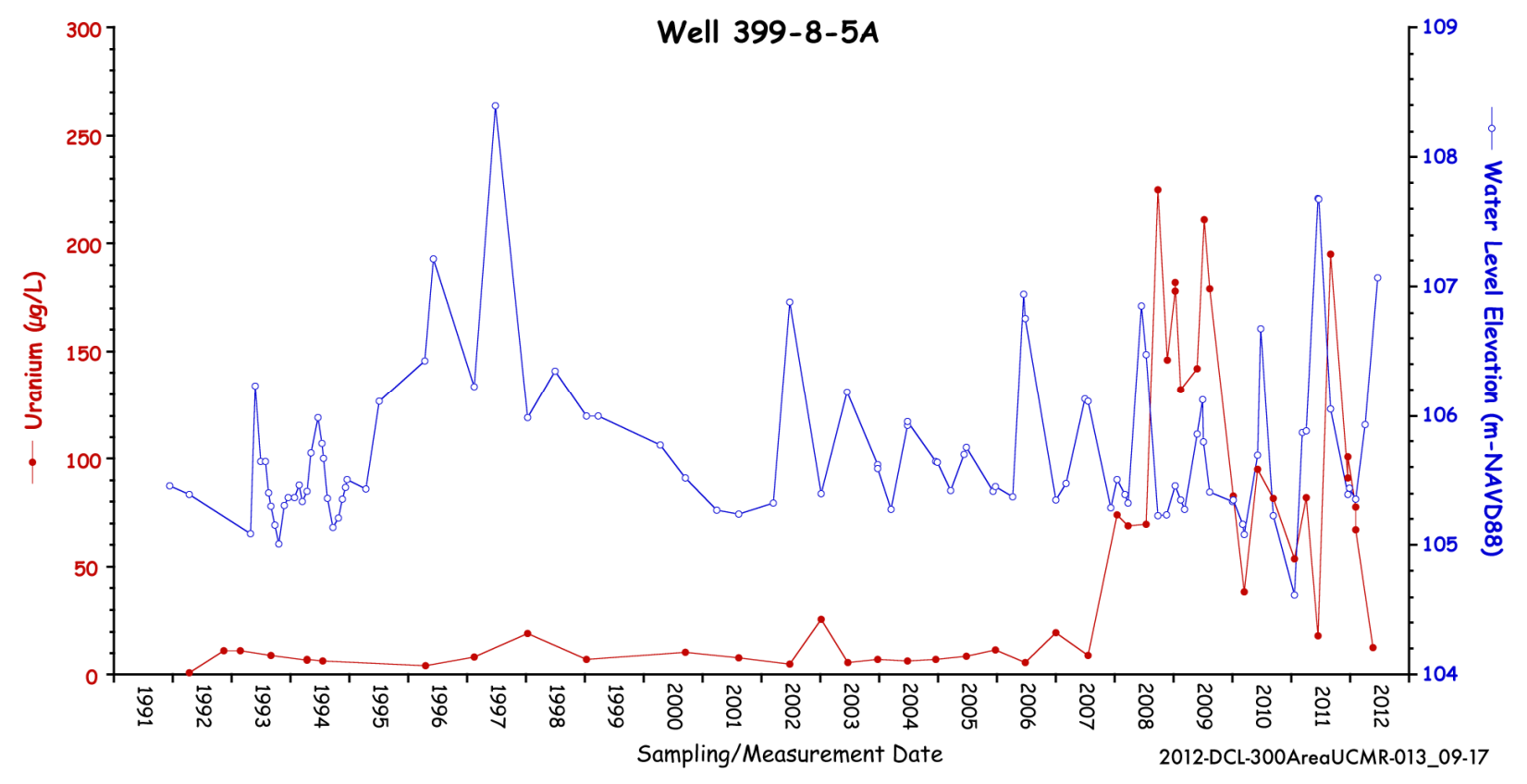

Figure 3.21. Uranium concentrations in well 399-8-5A downgradient from the 618-7 Burial Ground

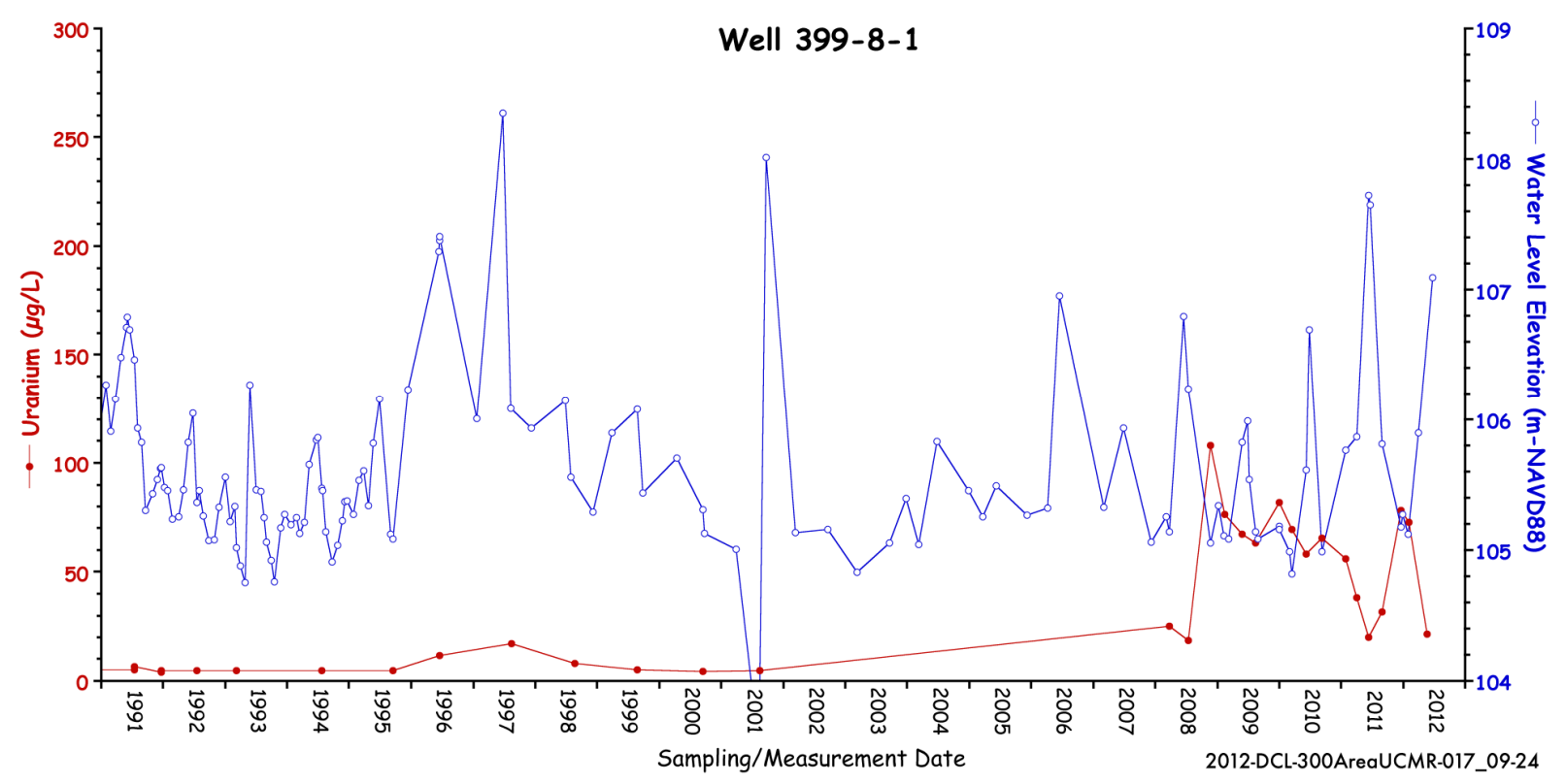

Figure 3.22. Water level and uranium concentration trends in well 399-8-1 


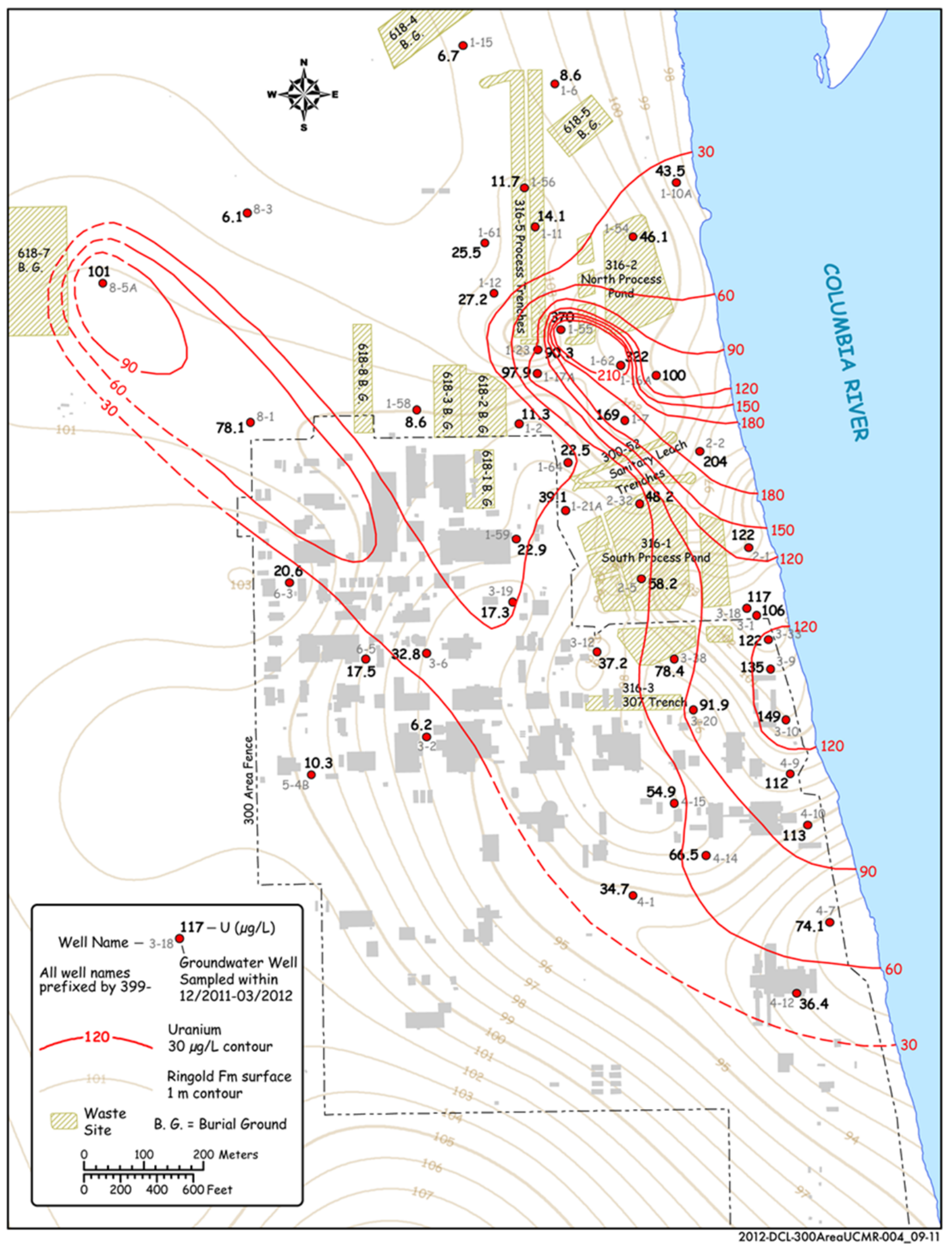

Figure 3.23. Maximum uranium concentrations in groundwater from December 2011 to March 2012 
Calculations of the plume parameters were extended from 2008 through 2012 with the same assumptions and methods as Peterson et al. (2008), but using EarthVision ${ }^{\circledR}$, which was used in the previous estimates for years 2006 and 2007. ${ }^{1}$ EarthVision ${ }^{\circledR}$ includes a more detailed representation of the spatial framework within which the uranium plume resides. Instead of assuming a contaminated thickness for the entire area covered by the plume, for each season (as done earlier), the most recent estimates used a representative water table position for each season and a newly revised surface for the Hanford and Ringold contact to calculate contaminated thicknesses throughout the grid for the model. The new estimates are shown along with the earlier estimates in Table 3.1.

The trend of the three plume parameters is shown in Figure 3.24. The revised estimate for December 2007 reflects change of the contaminated thickness calculated in EarthVision ${ }^{\circledR}$. The trend of areal extent and volume in Figure 3.24 appears to be increasing, but the dissolved mass of uranium shows a nearly constant trend throughout the decade. However, the increase in area and volume are within the likely bounds of uncertainty for the calculations. Sources of uncertainty impacting groundwater monitoring data are discussed in DOE-RL (2010). Beyond sample representativeness, additional uncertainty in calculating the plume parameters is contributed by subjectivity in drawing contour intervals for the plume and assumptions regarding aquifer thickness, porosity, and dilution by river-water intrusion.

\subsection{Groundwater Monitoring and Plume Parameter Implications}

Potential sources of uranium contamination to groundwater can be grouped into primary sources: 1) historic discharges of liquid waste; 2) unintentional releases from dry waste burial grounds, pipeline leaks, spills, etc.; 3) unintentional releases during site remediation and secondary sources; 4) remobilization/downward migration of residual uranium contamination in the vadose zone beneath primary source locations; and 5) remobilization of residual uranium contamination in the PRZ in source locations and areas of historic high groundwater contamination. The primary sources contributed the bulk of contaminant uranium to the aquifer and were observed both during historic operations as well as during remediation activities. The more recent contributions from remediation activities, which are substantial, can be tracked in groundwater to the river, providing estimates of uranium migration velocity. The secondary mobilization of contaminant uranium is evident in the monitoring data. Significant secondary sources exist in the 1) southern end of the 300 Area Process Trenches; 2) southwestern corner of the North Process Pond, which includes an unimproved spur of the 300 Area Process Sewer; 3) 307 Disposal Trenches; and 4) southwestern corner of the South Process Pond (DOE-RL 2010; Murray et al. 2012).

The current assessment of groundwater monitoring data has been limited by sampling frequency (e.g., quarterly, monthly). More detailed evaluation of the correlations (magnitude, timing, etc.) between water levels and uranium concentrations at various locations and under different hydraulic conditions, as described in the next section, may provide additional insight into secondary source locations and evolution of the groundwater plume as it migrates through heterogeneous macropore regions that are known to exist in 300 Area Hanford formation sediments. This information will be useful for implementation of successful remediation in the 300 Area.

\footnotetext{
${ }^{1}$ EarthVision is a registered trademark of Dynamic Graphics, Inc.
} 
Table 3.1. Estimated parameters for 300 Area uranium plume, 2002 to 2012

\begin{tabular}{|c|c|c|c|c|c|c|}
\hline \multirow[b]{2}{*}{$\begin{array}{l}\text { Time Period } \\
\text { Represented }\end{array}$} & \multicolumn{3}{|c|}{$>30 \mu \mathrm{g} / \mathrm{L}$ Portion of Plume: } & \multicolumn{3}{|c|}{$>10 \mu \mathrm{g} / \mathrm{L}$ Portion of Plume: } \\
\hline & $\begin{array}{c}\text { Area of } \\
\text { Plume } \\
\left(\mathrm{km}^{2}\right)\end{array}$ & $\begin{array}{c}\text { Volume of } \\
\text { Water } \\
\left(\mathrm{m}^{3}\right)\end{array}$ & $\begin{array}{c}\text { Mass of } \\
\text { Uranium } \\
(\mathrm{kg})\end{array}$ & $\begin{array}{c}\text { Area of } \\
\text { Plume } \\
\left(\mathrm{km}^{2}\right)\end{array}$ & $\begin{array}{c}\text { Volume of } \\
\text { Water } \\
\left(\mathrm{m}^{3}\right)\end{array}$ & $\begin{array}{c}\text { Mass of } \\
\text { Uranium } \\
(\mathrm{kg})\end{array}$ \\
\hline June 2002 & 0.42 & $1,060,626$ & 54.4 & 1.01 & $2,580,241$ & 84.8 \\
\hline December 2002 & 0.43 & 901,216 & 78.0 & 0.86 & $1,794,192$ & 95.8 \\
\hline June 2003 & 0.42 & $1,067,334$ & 54.9 & 0.87 & $2,211,604$ & 77.8 \\
\hline December 2003 & 0.32 & 673,342 & 40.7 & 0.87 & $1,808,715$ & 63.4 \\
\hline June 2004 & 0.40 & $1,008,386$ & 60.8 & 0.85 & $2,170,544$ & 84.0 \\
\hline December 2004 & 0.40 & 836,520 & 52.3 & 0.95 & $1,979,449$ & 75.2 \\
\hline June 2005 & 0.42 & $1,061,158$ & 76.2 & 1.12 & $2,852,401$ & 112.0 \\
\hline December 2005 & 0.41 & 846,596 & 63.0 & 0.96 & $1,988,448$ & 85.9 \\
\hline $\begin{array}{l}\text { June } 2006 \\
\text { (EarthVision }\end{array}$ & $\begin{array}{c}0.40 \\
(0.41)\end{array}$ & $\begin{array}{c}1,025,135 \\
(994,158)\end{array}$ & $\begin{array}{c}76.9 \\
(71.8)\end{array}$ & $\begin{array}{c}1.12 \\
(1.11)\end{array}$ & $\begin{array}{c}2,850,525 \\
(2,835,993)\end{array}$ & $\begin{array}{c}113.4 \\
(105.2)\end{array}$ \\
\hline $\begin{array}{l}\text { December } 2006 \\
\text { (EarthVision }^{\mathrm{TM}} \text { ) }\end{array}$ & $\begin{array}{c}0.48 \\
(0.48)\end{array}$ & $\begin{array}{c}1,003,316 \\
(942,429)\end{array}$ & $\begin{array}{c}78.8 \\
(64.6)\end{array}$ & $\begin{array}{c}0.74 \\
(0.73)\end{array}$ & $\begin{array}{c}1,536,019 \\
(1,524,363)\end{array}$ & $\begin{array}{l}89.4 \\
(76.7)\end{array}$ \\
\hline $\begin{array}{l}\text { June } 2007 \\
\text { (EarthVision }\end{array}$ & $\begin{array}{c}0.50 \\
(0.50)\end{array}$ & $\begin{array}{c}1,263,458 \\
(1,280,611)\end{array}$ & $\begin{array}{c}82.9 \\
(77.9)\end{array}$ & $\begin{array}{c}0.83 \\
(0.84)\end{array}$ & $\begin{array}{c}2,119,758 \\
(2,206,019)\end{array}$ & $\begin{array}{l}100.1 \\
(95.6)\end{array}$ \\
\hline December $2007^{(a)}$ & 0.42 & 728,634 & 43.5 & 0.97 & $1,779,638$ & 62.0 \\
\hline June 2008 & 0.54 & $1,202,220$ & 57.4 & 1.12 & $2,510,294$ & 80.0 \\
\hline December $2008^{(b)}$ & 0.43 & 753,077 & 45.8 & 1.00 & $1,831,501$ & 66.5 \\
\hline June 2009 & 0.53 & $1,250,062$ & 65.7 & 1.09 & $2,455,079$ & 86.3 \\
\hline December 2009 & 0.50 & 946,647 & 49.8 & 0.93 & $1,740,837$ & 66.9 \\
\hline June 2010 & 0.61 & $1,438,491$ & 75.1 & 1.01 & $2,298,549$ & 91.5 \\
\hline \multicolumn{7}{|l|}{ December $2010^{(\mathrm{c})}$} \\
\hline June 2011 & 0.48 & $1,064,096$ & 64.3 & 0.91 & $2,066,360$ & 84.3 \\
\hline December 2011 & 0.57 & $1,064,833$ & 71.7 & 0.92 & $1,715,957$ & 84.2 \\
\hline
\end{tabular}

(a) All estimates for post-June 2007 were derived using EarthVision $\AA$ and a revised spatial framework.

(b) Estimates do not include the new plume resulting from remedial action at the 618-7 Burial Ground.

(c) Incomplete data set for December 2010; partial set available for January 2011.

Assumptions for calculations prior to December 2007:

- Contaminated thickness: $9.8 \mathrm{~m}$ (June) and $8.0 \mathrm{~m}$ (December).

- Total porosity: $26 \%$.

- Mass is estimated using mid-point concentration between map contours.

Assumptions for calculations starting in December 2007:

- Contaminated thickness uses EarthVision ${ }^{\circledR}$ database, as updated by drilling in 2010.

- Estimates derived using EarthVision ${ }^{\circledR}$ software at Pacific Northwest National Laboratory during September 2012.

- (Other assumptions remain the same as for pre-December 2007 calculations).

Source: Values for seasonal periods prior to December 2007 are from PNNL-17034, Table 3.3. 


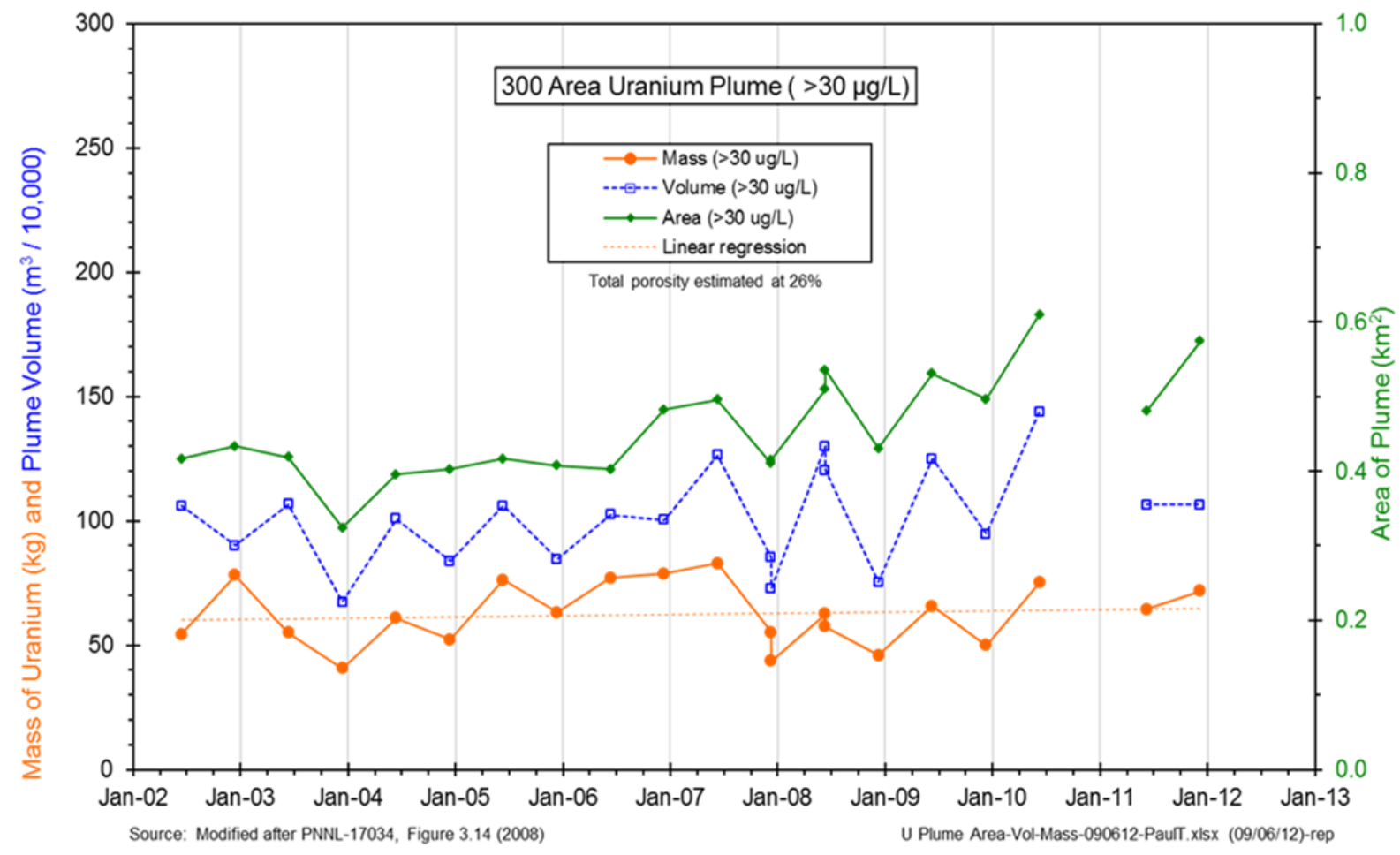

Figure 3.24. Estimated area, volume, and mass of the 300 Area uranium plume, 2002 to 2012 


\subsection{Mechanisms of Uranium Recharge to the Plume}

Quarterly and monthly monitoring data, such as those summarized in the preceding section, have long revealed both positive and negative correlations between well-water uranium concentrations and water table elevation. Vadose zone solubilization and groundwater dilution by intruding river waters have been identified as influential processes. However, the site monitoring record is not sufficiently robust on a temporal scale to resolve the above-mentioned questions about the causes of lag between high water level and high groundwater uranium needed to identify the locations of remaining PRZ uranium sources sustaining the plume. Detailed monitoring experiments at the IFRC site in the South Process Pond were consequently performed to identify correlations between well-water concentrations, the vertical distribution of sorbed uranium, and water table elevation. In general, the spring high water table event was found to have a profound influence on groundwater uranium concentrations at the IFRC site. However, the details of response and the identification of controlling factors and variables are far more complex than anticipated. Describing the observed behaviors by models has not yet been achieved (although it is a continuing focus) because of uncertainties associated with an unknown spatial inventory of sorbed uranium, and highly dynamic effects resulting from frequent stage changes of the Columbia River and transient geochemical effects resulting from groundwater-river exchange and inland river-water intrusion.

The IFRC has performed high-density temporal sampling of its three, multilevel well clusters and other select wells located near known sorbed uranium hotspots for calendar years 2010, 2011, and 2012. The IFRC site is located near the inland limit of spring river-water intrusion, experiencing river-water intrusion during 3 of the last 4 years. The three well clusters are located in the north, east, and southern quadrants of the IFRC well field (Figure 2.7, schematic of the IFRC well field); and are at different distances from the river shoreline (e.g., 150 to $200 \mathrm{~m}$ ). The three wells within each of the clusters are screened over 1-m intervals in the upper, central, and deeper zones of the aquifer. The upper and lower zones exhibit hydraulic conductivities of approximately $7000 \mathrm{~m} / \mathrm{d}$, while the intermediate zone is lower at $2000 \mathrm{~m} / \mathrm{d}$.

\subsection{Comprehensive IFRC Monitoring Data from 2011}

Monitored uranium concentrations in shallow wells that are screened in the upper meter of the saturated zone and the lower meter of the PRZ display significant variability between different spatial locations in the IFRC well field, and complex temporal behaviors during the period of high water table in the spring (Figure 4.1 and Figure 4.2; U2011/WL2011 and U2011/SpC for wells 399-2-30 and 399-3-26, respectively). Well-water uranium concentrations increase almost immediately when the water table elevation moves into the lower vadose zone (105.5 $\mathrm{m}$ and higher) during the initial stages of the spring snowmelt pulse. There is no observed lag time for solubilization. The extent of increase was highly variable between wells, reaching for example, $300 \mu \mathrm{g} / \mathrm{L}$ for well 3-30 and $60 \mu \mathrm{g} / \mathrm{L}$ for well 399-2-26. For all wells studied, the magnitude of this initial increase showed moderate correlation (e.g., $r^{2} \approx .72$ ) with bicarbonate extractable uranium (BEU) measured on borehole sediments (data and analysis in Murray et al. 2012) as shown in Figure 4.1a and Figure 4.2a. The concentration of sorbed uranium was consequently not the only variable that controls this response. Well-water uranium concentrations decreased during the period of highest water table (106.5-107.5) and then increased again in both wells as the water table fell. This particular response, common to all wells monitored, resulted from the intrusion 
a.)
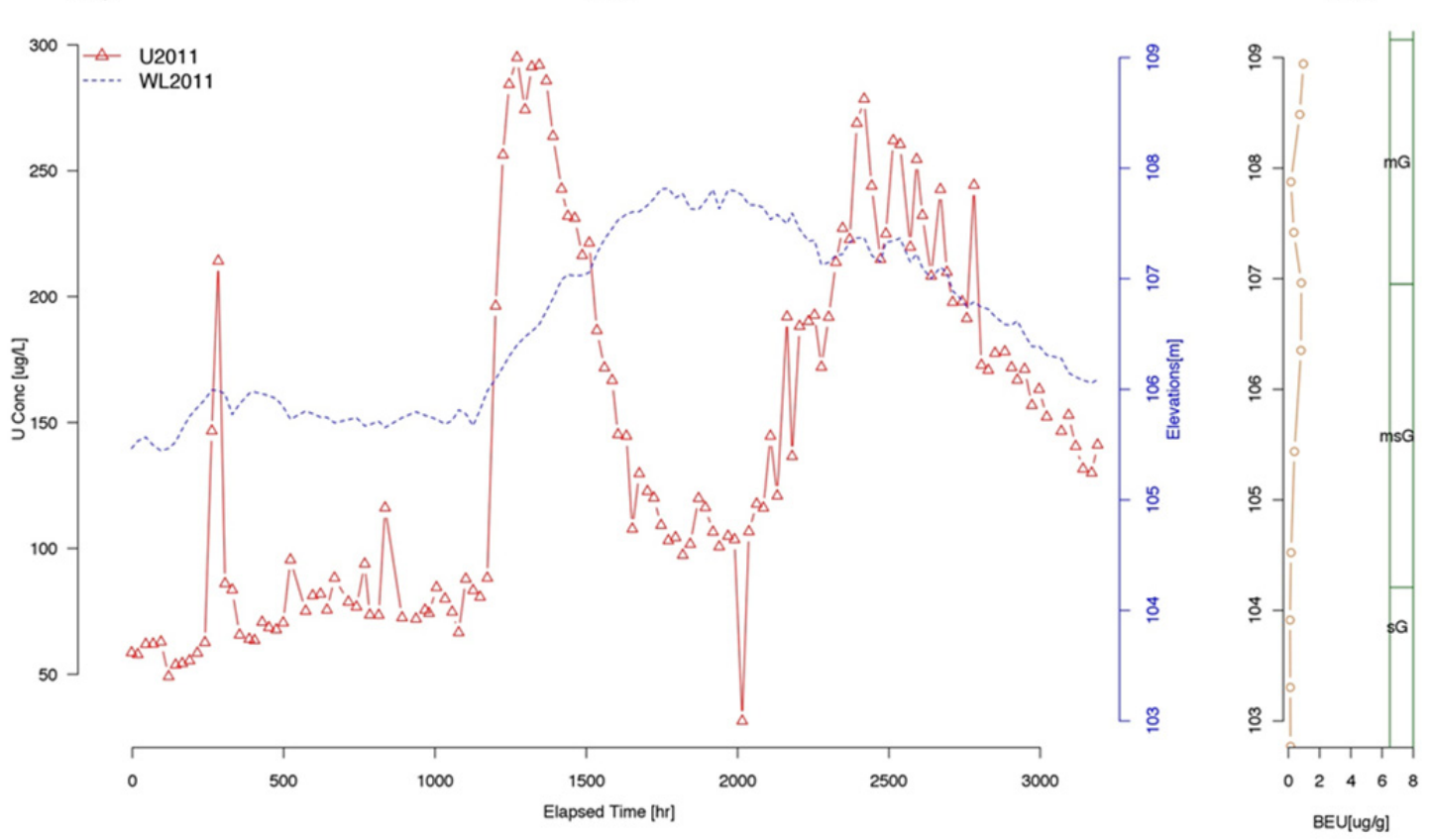

b.)

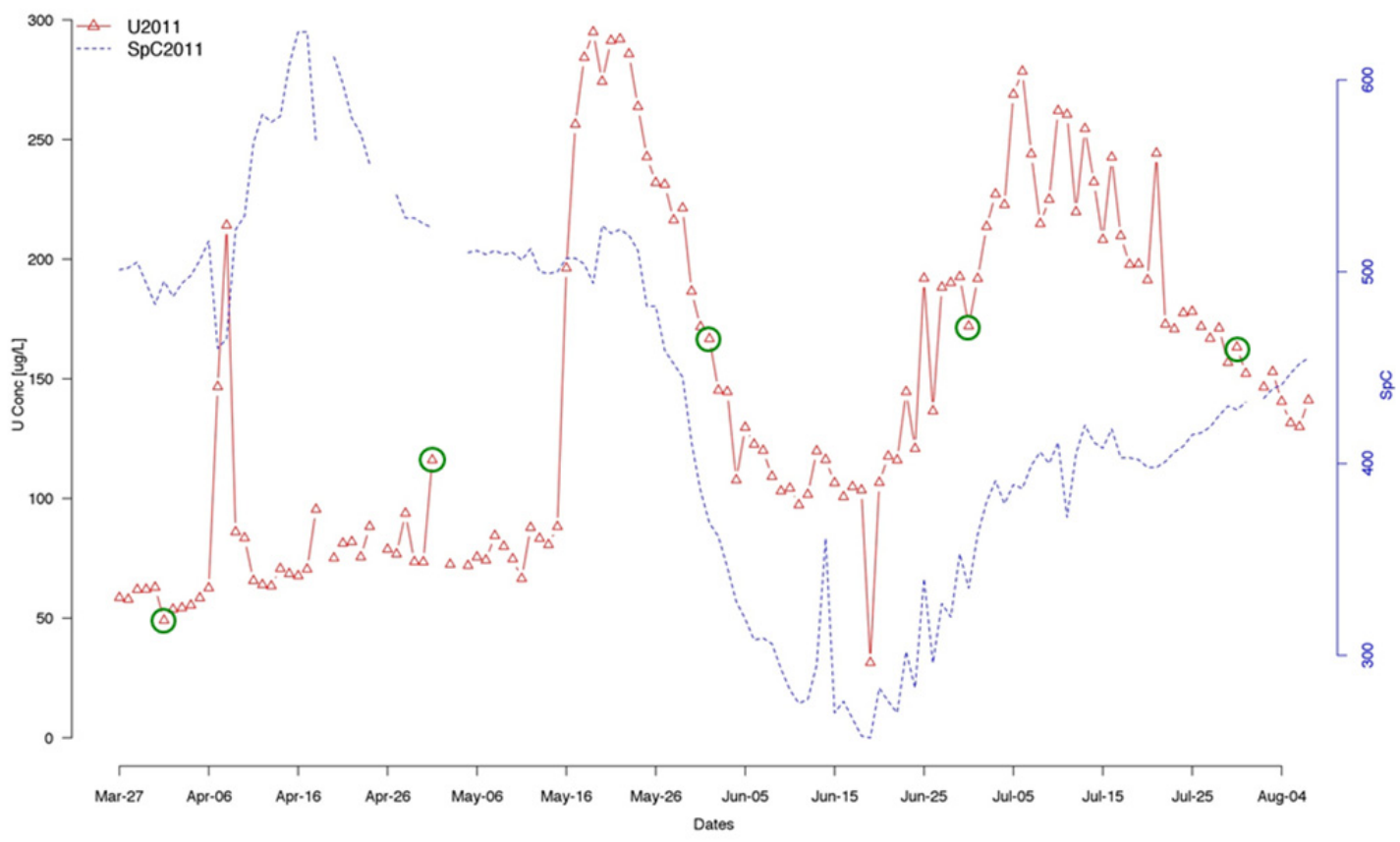

Figure 4.1. Uranium concentration, water table elevation, and specific conductivity data for IFRC well 399-3-30 during 2011. Green circles define the date trend that would be obtained by monthly sampling. The vertical distribution of bicarbonate extractable uranium as measured in sediments collected from the borehole are presented adjacent to panel a. 
a.)

2-26

$2-26$

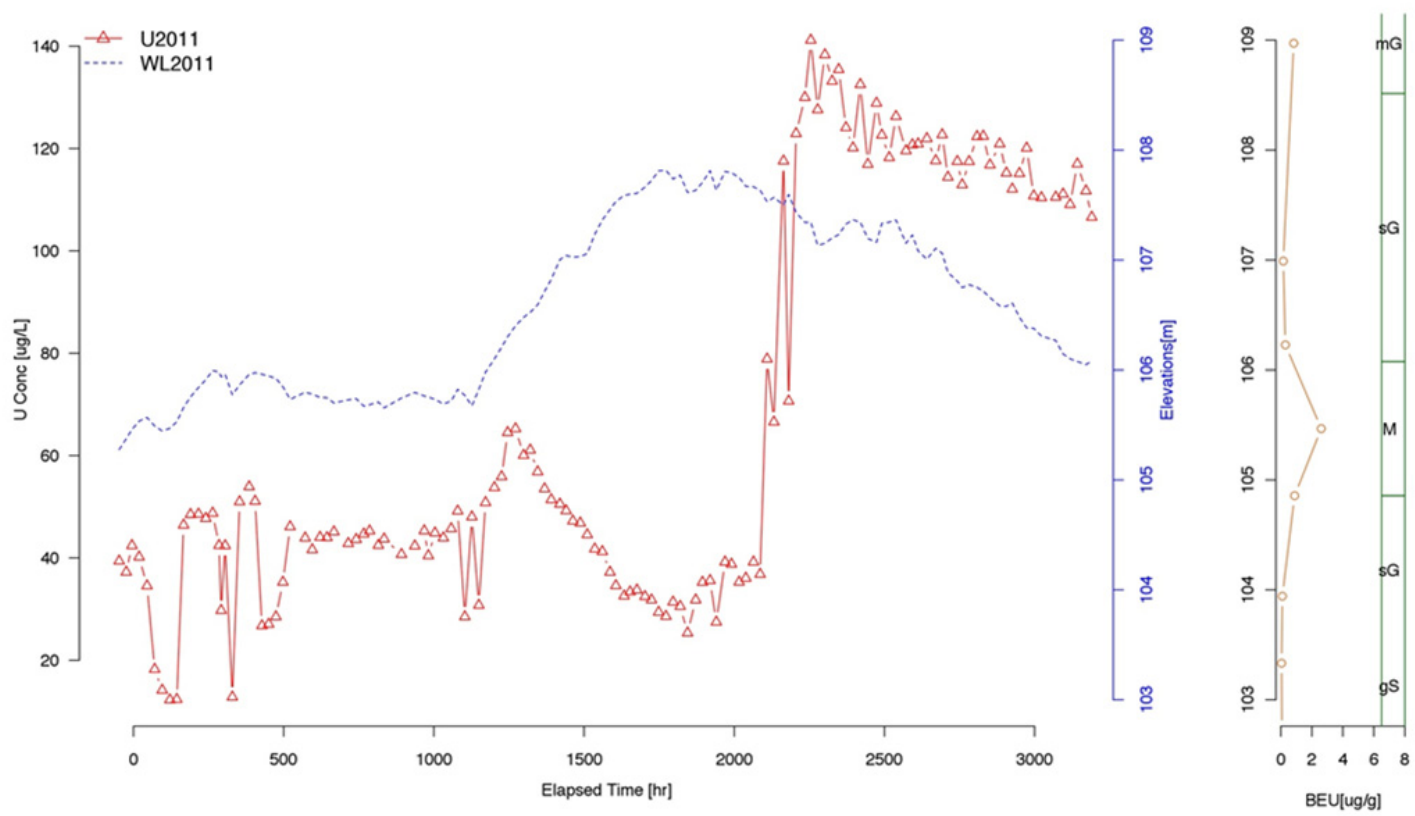

b.)

399-2-26

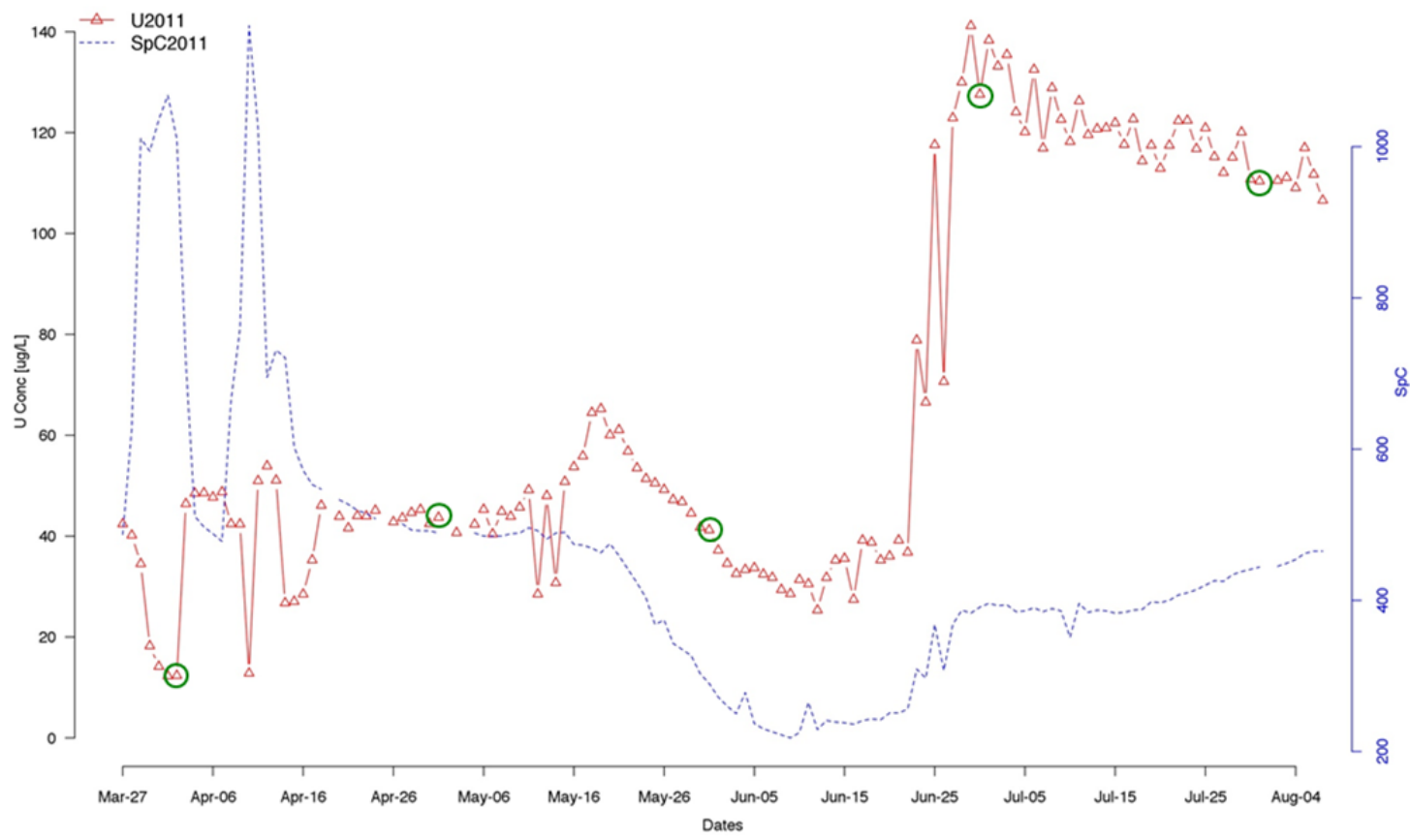

Figure 4.2. Uranium concentration, water table elevation, and specific conductivity data for IFRC well 399-2-26 during 2011. Green circles define the trend that would be obtained by monthly monitoring. The vertical distribution of bicarbonate extractable uranium as measured in sediments collected from the borehole are presented adjacent to panel a. 
of river water as revealed by contemporaneous measurements of specific conductance (Figure $4.1 \mathrm{~b}$ and Figure 4.2b) and $\mathrm{Cl}^{-}$discussed below. Uranium concentrations decreased in parallel with decreasing specific conductance (a measure of soluble salts) in both wells during the leading edge of river-water intrusion. The extent of concentration rebound during the falling water table and river-water retreat (displacement by groundwater with higher salt content) was much greater for well 399-2-26, where final uranium concentrations significantly exceeded the initial mobilized pulse. A robust analysis of these data sets, including hydrodynamic effects (McKinley et al. In Press ${ }^{1}$ ), suggests that while all uranium in well 399-3-30 originated from sediments near the borehole, the rebound (second) peak in well 399-2-26 $(2100-3000 \mathrm{~h})$ represented uranium that was transported to the IFRC from an offsite source.

For water year 2011, the period of peak water table elevation (May 10 to July 1) coincided with a river-water intrusion event that pervaded all depths of the uranium plume as defined by chloride analyses (Figure 4.3). River water intrusion changes the groundwater flow direction (from the southeast to the southwest) and alters groundwater composition. Tracer tests in the upper aquifer at the onset of high water suggest a groundwater velocity of approximately $2 \mathrm{~m} / \mathrm{d}$, which is at the low end of groundwater velocities observed during free drift injection experiments. Spring chloride concentrations in the Columbia River average $3 \mathrm{mg} / \mathrm{L}$, and the appearance of similar values at shallow and intermediate depths of the aquifer over the approximate period of June 1 to June 20 indicate complete displacement of groundwater by river water. Generally, the intrusion of river water into the deepest regions of the plume was delayed by 7 to 10 days over the shallow region, and the displacement of deep groundwater was incomplete (e.g., chloride concentrations of $5-10 \mathrm{mg} / \mathrm{L}$ at peak intrusion). The presence of groundwaterriver water mixing within the plume is significant for two reasons: 1) river water dilutes groundwater and reduces uranium plume concentrations through mixing; and 2) river water contains three times less bicarbonate than does groundwater, which reduces uranium solubilization (desorption) from the PRZ during the high water table period and increases uranium adsorption to sediments within the plume. Differentiating between these effects on the data shown in Figure 4.1 and Figure 4.2 or even identifying the primary mechanism is difficult. Effects of river-water intrusion on uranium concentrations were observed at all plume depths in 2011 (Figure 4.4).

During winter months and long after preceding spring-mobilized uranium has been assimilated into the plume, groundwater concentrations in the IFRC tend to decrease with depth in the plume from $40-60 \mu \mathrm{g} / \mathrm{L}$ near the surface to approximately $25 \mu \mathrm{g} / \mathrm{L}$ at depth. The increase in water table elevation during spring immediately increases uranium concentrations in shallow wells, with a slight impact noted at intermediate depth. The effects of river-water intrusion are noted at all depths in all wells through a reduction in uranium concentrations between May 17 and approximately August 1 (Figure 4.4). Vadose zone-mobilized uranium begins to mix with and appear in the intermediate and deeper zones of the plume in north and eastern quadrants of the IFRC with considerable delay (e.g., 30-50 d) as the water table falls, river water retreats, and groundwater re-invades the plume at all depths. At this point, groundwater uranium concentrations at depth exceed those in the initial mobilization event for two of the well clusters (north and east), although the origin (desorption, vertical mixing, offsite transport) is uncertain. The temporal trends in and magnitude of uranium concentrations with depth are quite variable between the three well clusters in the $1600-\mathrm{m}^{2}$ IFRC domain, although the similarity in their behavioral patterns and time-scale of response indicates control by the same hydrologic and geochemical processes.

\footnotetext{
${ }^{1}$ McKinley JP, J Zachara, CT Resch, RM Kaluzny, MD Miller, VR Vermeul, BG Fritz, and JV Moser. In Press. "River Water Intrusion and Contaminant Uranium Contributions to Groundwater During the Annual Spring Rise in Columbia River Stage at the Hanford Site 300 Area, Washington.” Environmental Science \& Technology.
} 
a.)
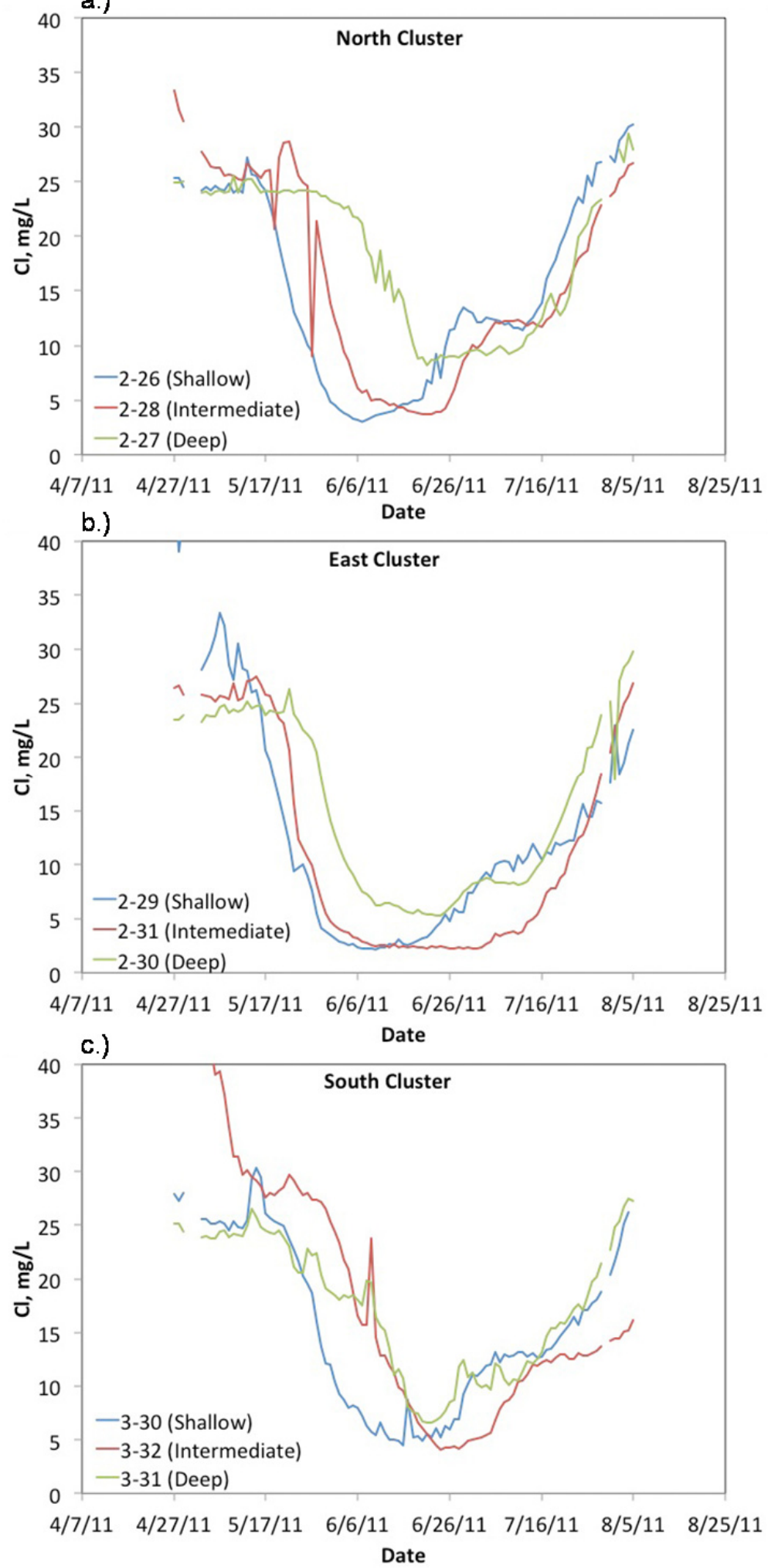

Figure 4.3. Chloride concentrations in waters from the three IFRC multiple-depth clusters during spring 2011. Blue is shallow depth, red is intermediate depth, and green is deep. 

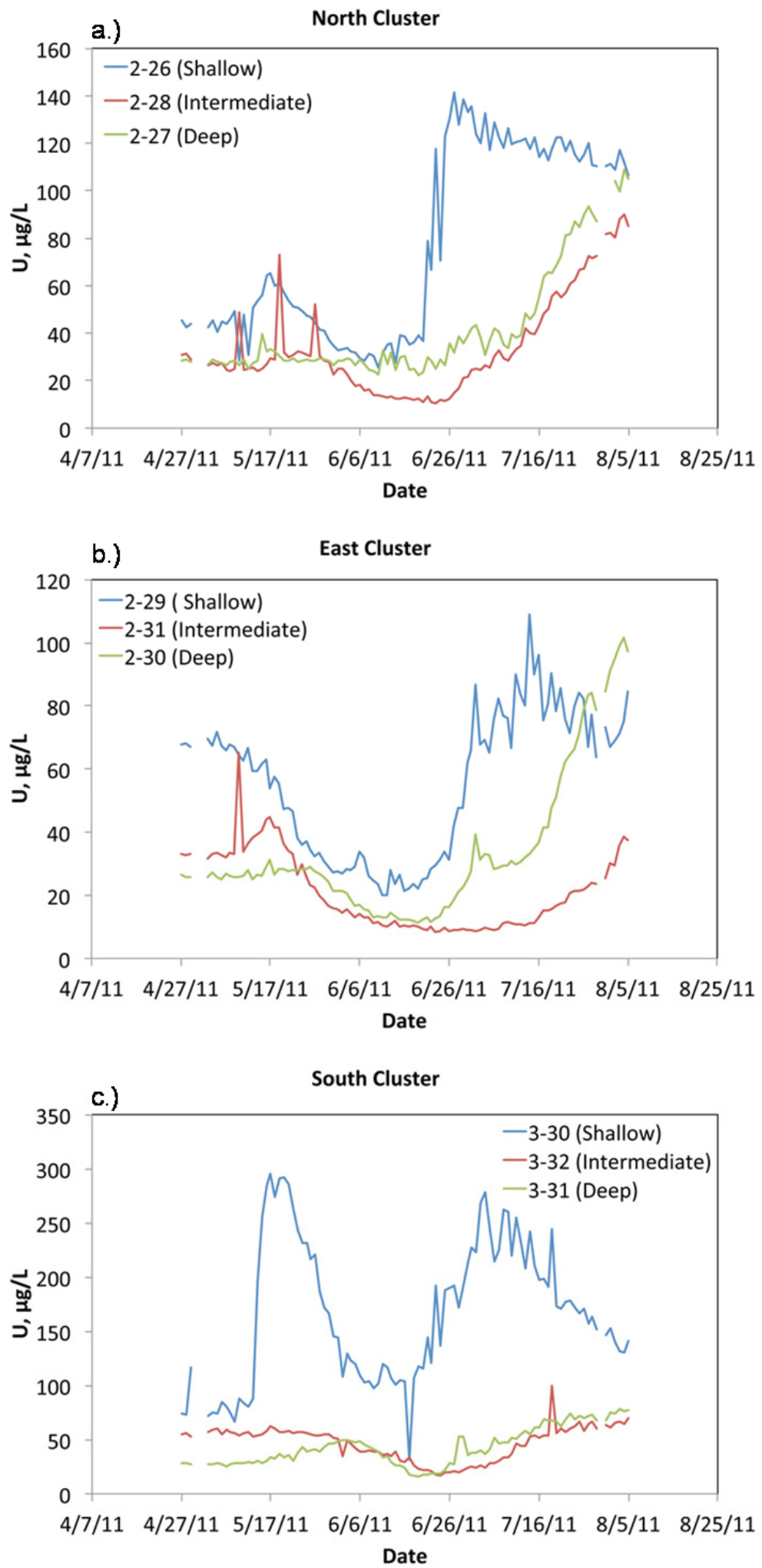

Figure 4.4. Uranium concentrations in waters from the three IFRC multiple-depth clusters during spring 2011. Blue is shallow depth, red is intermediate depth, and green is deep. 


\subsection{Annual Variations in Vadose Zone Uranium Mobilization}

The previous discussion focused only on monitoring data from water year 2011 to illustrate key details. However, the timing and magnitude of the spring snowmelt event in the Columbia River varies dramatically on a year-to-year basis (see Figure 2.3), and these variations have strongly influenced uranium solubilization from the PRZ over the 3 years of intense monitoring at the IFRC, and the impact of this uranium on groundwater concentrations. For example, the spring snowmelt event in 2010 occurred at a later date and was of lesser magnitude than in 2011 (Figure 2.3). Both differences in well-water uranium concentrations and similarities in trends and relationships were observed for the two shallow reference wells discussed above (wells 399-2-30 and 399-3-26; Figure 4.5 and Figure 4.6). In 2010, uranium concentrations in well 399-3-30 again rose dramatically when the water table increased above $106 \mathrm{~m}$, albeit with a 1-month delay (June 12), reaching a final concentration of $325 \mu \mathrm{g} / \mathrm{L}$, which was similar to 2011 (Figure 4.5a). However, the peak water table elevation (106.8 m) was well below that in $2012(107.5 \mathrm{~m})$, resulting in far less river-water intrusion (note specific conductivity [SpC] in Figure $4.5 \mathrm{~b}$ ) and a very different temporal profile of uranium with sustained high concentrations from June 12 to July 2. Absent was the decline in uranium concentrations at peak water levels observed in 2011 and attributed to river-water intrusion. In contrast, the behavior of uranium in well 399-2-26 during 2010 was similar to that in 2011 with 1) a small increase in concentration noted when the water table elevation exceeded $105.5 \mathrm{~m}$; 2) a subsequent decrease at high water table as $\mathrm{SpC}$ decreased; and 3) a peak in uranium concentration with asymptotic decay during the period of falling water table. The absence of river-water intrusion and vadose zone solubilized uranium in the intermediate and deeper cluster wells was also noted in 2010. The high $\mathrm{SpC}$ values observed from June 2 through June 12, 2010, resulted from a tracer experiment that was performed to assess groundwater velocities immediately before the spring high water event.

\subsection{Implications of Uranium Plume Recharge}

Research at the Hanford IFRC site has shown that uranium is mobilized from the lower vadose zone in concentrations exceeding the DWS during the spring high water table event. All 30 shallow-screened IFRC wells demonstrate this behavior to various degrees, showing large fluctuations in uranium concentration over the approximate 3-month period of spring snowmelt. Knowing the extent, timing, and causes of this dynamic behavior is critical to the understanding of site-wide monitoring data collected on a monthly or quarterly frequency, and for any planned remediation of the lower vadose zone. Monthly monitoring might capture the overall behavior of some wells (e.g., well 399-2-26), but might be inadequate for others (e.g., well 399-3-30) (see green circles in Figure 4.1 and Figure 4.2). These conditions might change the following year. Concentration fluctuations result from complex and coupled hydrophysical and geochemical effects (e.g., groundwater velocity, direction, and compositional changes) superimposed on a spatially heterogeneous distribution of sorbed uranium. The high degree of complexity noted in the temporal behaviors of uranium in individual wells indicates the process is multidimensional and not simply mobilization as the water table elevation increases. Vadose zone mobilization leads to higher uranium concentrations monitored in shallow depths of the plume during all years and higher concentrations throughout the entire plume thickness for select years with high degrees of river-water intrusion. These behaviors strongly impact monitoring results, and should be considered in their interpretation. While qualitative interpretations of this behavior are possible (as shown herein) to support conceptual model development and the identification of hypotheses for future research, the process is not sufficiently understood, even within the well-studied and characterized IFRC domain, to predict behaviors in future years. 

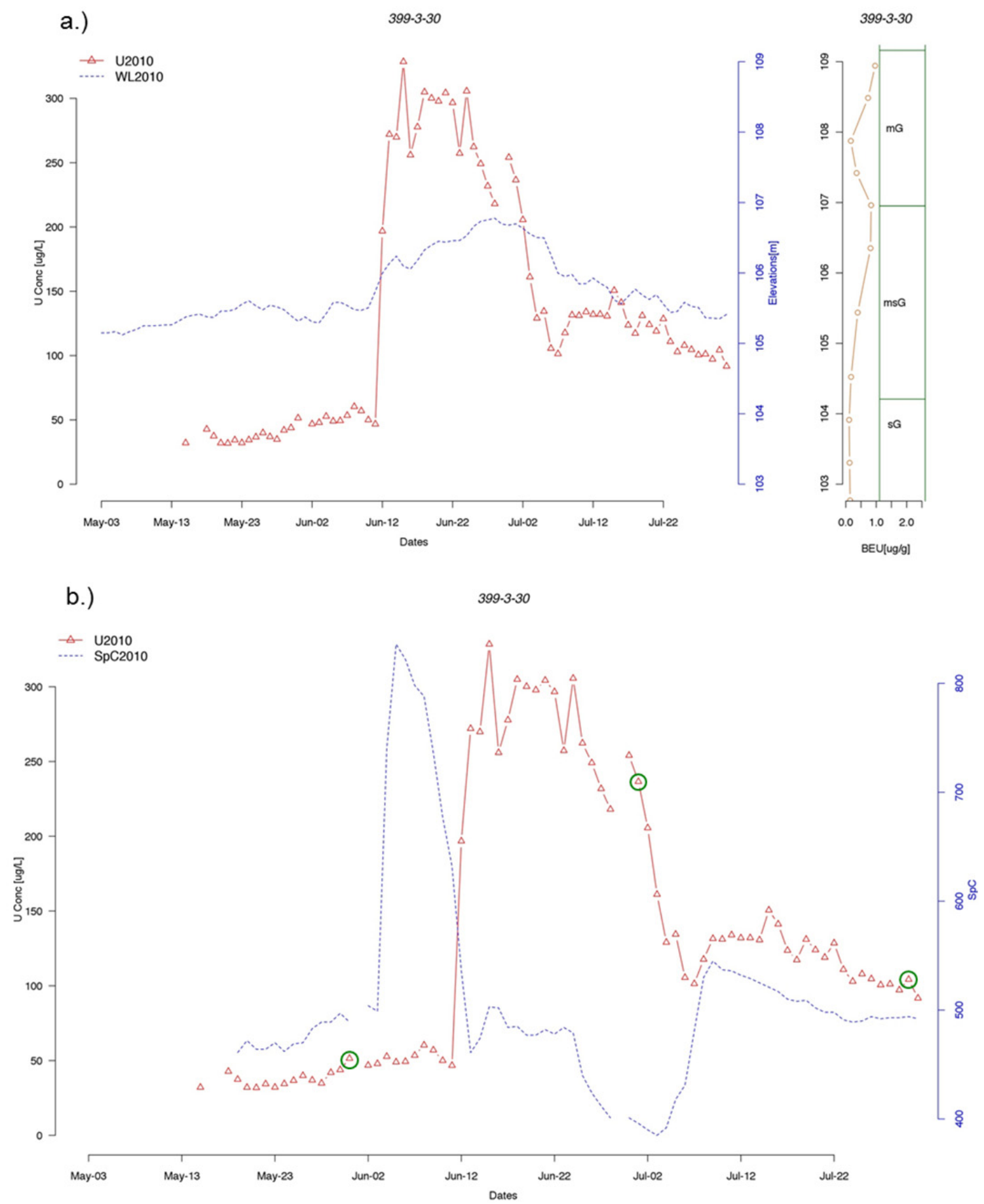

Figure 4.5. Uranium concentration, water table elevation, and specific conductivity data for IFRC well 399-3-30 during 2010. Green circles define the trend that would be obtained by monthly monitoring. The vertical distribution of bicarbonate extractable uranium as measured in sediments collected from the borehole are presented adjacent to panel a. 


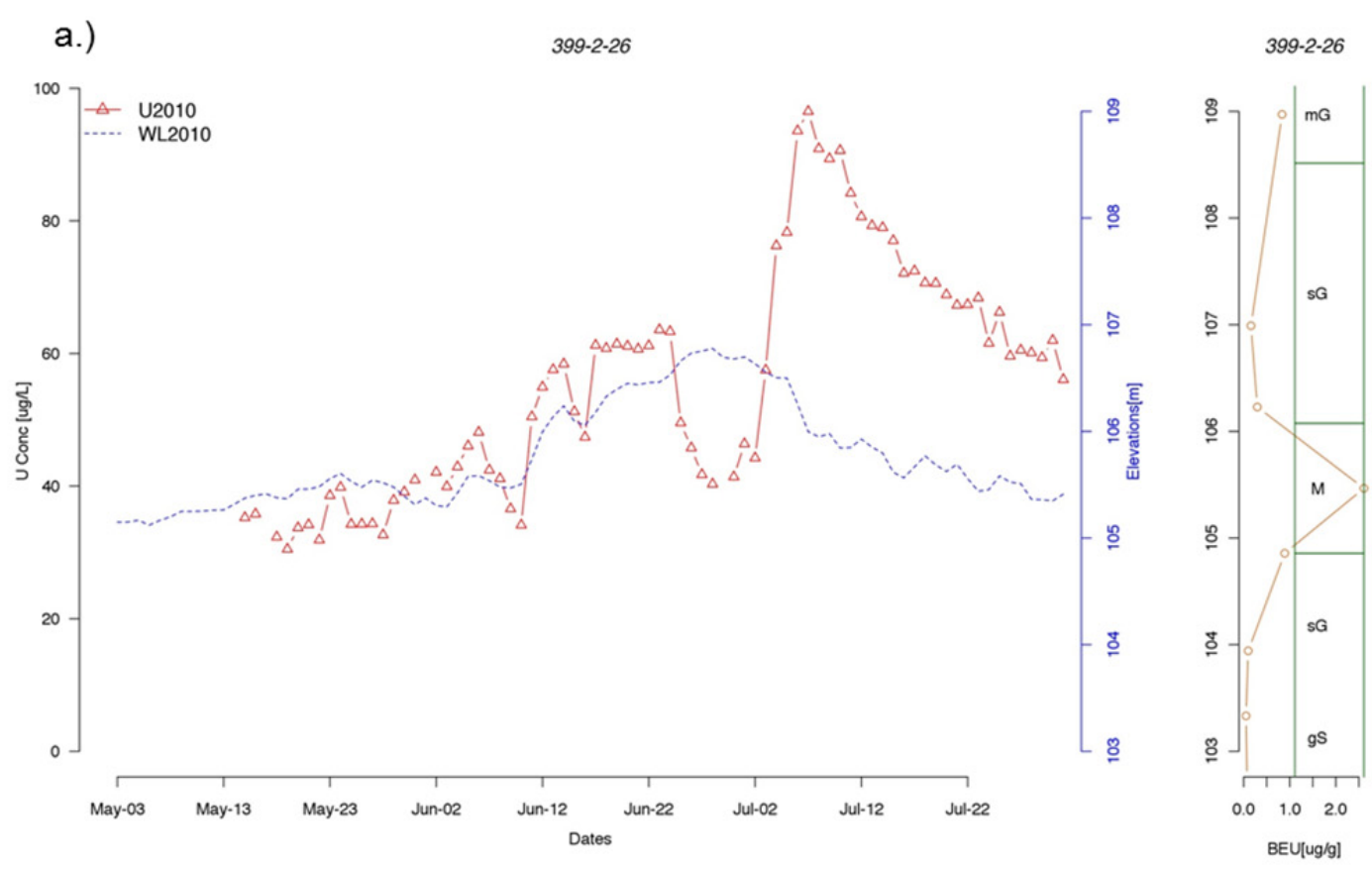

b.)

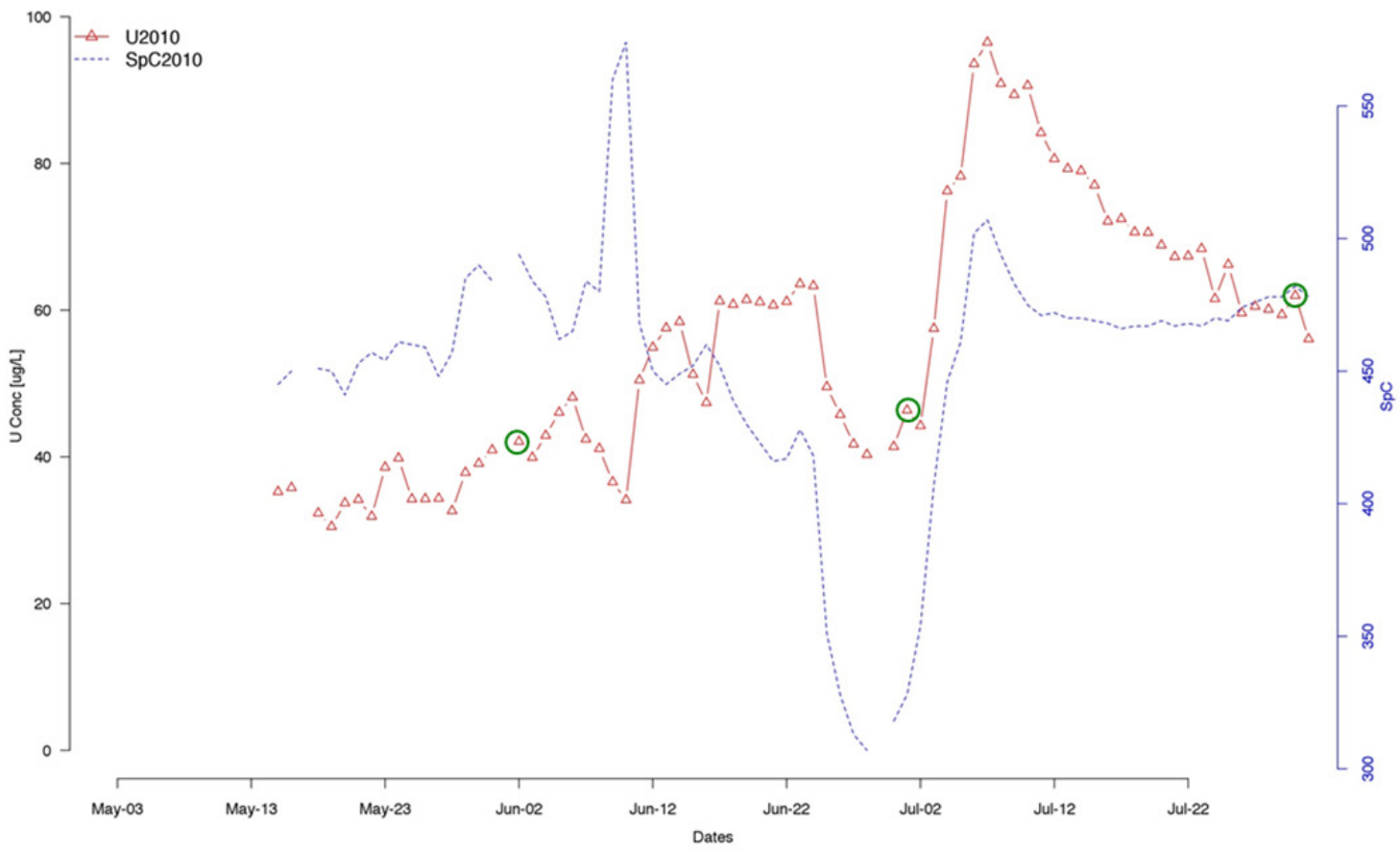

Figure 4.6. Uranium concentrations, water table elevation, and specific conductivity data for IFRC well 399-2-26 during 2010. Green circles define the trend that would be obtained by monthly monitoring. The vertical distribution of bicarbonate extractable uranium as measured in sediments collected from the borehole are presented adjacent to panel a. 
It is currently unclear whether behaviors observed within the IFRC well field in the South Process Pond are representative of the entire plume. The IFRC well field lies at the inland boundary of the highly dynamic groundwater-river mixing zone. It experiences river-water intrusion only at the highest Columbia River stages that occur at peak snowmelt in the spring. Other more inland monitoring wells in the 300 Area plume experience water table fluctuations without compositional changes, while others closer to the river experience repeated events of water table fluctuation and river-water intrusion during the year. These differences are highly significant to uranium geochemical and reactive transport behavior. A major challenge that remains is to reconcile multiyear, temporally intense monitoring data for the spring mobilization event with a common conceptual and numeric model. Representative wells should be selected for this activity that lie at different distances from the river, reside within primary transport pathways controlled by Hanford and Ringold contact topography, and are proximate to potential source areas or discharge points to the Columbia River. 


\subsection{Geochemical Processes Controlling Plume Persistence}

Geochemical retardation mechanisms strongly influence plume persistence by concentrating contaminant uranium on sediment particles, controlling the release rate of residual uranium to pore water, and slowing its migration velocity through aquifer sediments and its discharge to the Columbia River. This concentration mechanism occurs by the precipitation of discrete, uranium-containing mineral phases (e.g., cuprosklodoskite or metatorbernite [Arai et al. 2007; Singer et al. 2009]) in infrequent high concentration zones, or more commonly by the surface complexation (adsorption) of dissolved U(VI) species to reactive sites on fine-grained mineral forms in the sediment (e.g., quartz and phyllosilicates [Bond et al. 2008; Stoliker et al. 2011; Wang et al. 2011; Stoliker et al. In Press ${ }^{1}$ ]). The magnitude and rates of these reactions have been extensively studied on contaminated sediments from various locations in the 300 Area including the vadose zone, PRZ (within and outside the waste site footprints), and the saturated zone within the IFRC. A lengthy discussion of this topic is provided by DOE-RL (2010) and "best estimate values" for adsorption coefficients $\left(\mathrm{K}_{\mathrm{d}}\right.$ values as empirical surface complexation parameters) were derived from laboratory measurements and used in calculations to estimate the potential duration of plume persistence under natural conditions. However, no model simulation has yet to use the known distribution of both precipitated and adsorbed phases, and their markedly different kinetic release behaviors, to estimate plume persistence.

It is important to emphasize how the magnitude of the adsorption coefficients and the mass of precipitated uranium phases exert a major influence on the computed duration of plume persistence given the small and relatively uniform hydrologic flux of the plume to the Columbia River. Since completion of the DOE-RL (2010) study, multiple field injection experiments have been performed at the IFRC site to assess both the magnitude and rates of in situ adsorptive retardation in the aquifer. The results of these experiments provide important new insights into plume scale adsorption-desorption behavior and the magnitude of adsorption coefficients to be used in future persistence calculations. The magnitude of in situ retardation, in general, has been found to be lower than previously reported.

\subsection{Laboratory Measurements of Adsorption and Desorption}

An extensive data set of laboratory measurements, performed by multiple investigator teams for different purposes, exists for U(VI) adsorption/desorption behavior on 300 Area sediments. These measurements have most commonly been performed on the $<2-\mathrm{mm}$ size fraction of the sediment isolated by dry-sieving because sorbed U(VI) in contaminated sediments is primarily associated with this fraction (Shang et al. 2011). (Note that dry-sieving is not free of artifacts because fine-grained particles bind tenaciously to larger ones and are not effectively separated by this method.) The use of these measurements for field-scale predictions require that the overall $\mathrm{K}_{\mathrm{d}}$ value be scaled to the mass fraction of $<2$-mm material in the sediment, which is generally small (e.g., $~ 10 \%$ [Murray et al. 2012]). It is difficult to assess this data set holistically because U(VI) adsorption/desorption is very sensitive to the aqueous chemical conditions used for experimentation, and these vary throughout the data set. Another important

\footnotetext{
${ }^{1}$ Stoliker DL, C Liu, DB Kent, and JM Zachara. In Press. “Characterizing Particle-Scale Equilibrium Adsorption and Kinetics of Uranium(VI) Desorption from U-Contaminated Sediments." Water Resources Research.
} 
variable in the data set is time to reach equilibration, which is observed to vary significantly and is inconsistent. The adsorption and desorption process of uranium in contaminated 300 Area sediments has been shown to be slow and kinetically controlled, requiring kinetic $K_{d}$ (Qafoku et al. 2005) or kinetic surface complexation models (Yin et al. 2011; Stoliker et al. In Press ${ }^{1}$ ) for appropriate description. This kinetic behavior is believed to result from the integrated effects of several factors: 1) a long in-ground residence time of contaminant uranium has allowed its diffusion into internal pores and fractures of lithic fragments and aggregates of variable size, requiring lengthy periods; and 2) historic waste-sediment reactions in the vadose zone beneath the former waste disposal facilities have created mineral precipitates and coatings that trap uranium in transport-limited domains. As a result of these factors, the desorption of contaminant uranium from the 300 Area vadose zone, PRZ, and saturated zone sediments can take extended time periods (e.g., $>1000 \mathrm{~h}$ ), challenging $\mathrm{K}_{\mathrm{d}}$ measurement and its application.

The $\mathrm{K}_{\mathrm{d}}$ concept is particularly challenging for the 300 Area system, because of strong kinetic (mass transfer) behaviors to adsorption; surface complexation that is very sensitive to $\mathrm{pH}$, and the concentrations of $\mathrm{Ca}^{2+}$ and $\mathrm{HCO}_{3}{ }^{-}$; and transient chemical composition in the plume resulting from riverwater intrusion and groundwater-river mixing. However, $\mathrm{K}_{\mathrm{d}}$ does have heuristic merit for discussions of the magnitude of adsorption in 300 Area sediments because of its simplicity in formulation and transparency in relation to the retardation factor (Langmuir 1997). IFRC investigators have developed a surface complexation model to predict the $\mathrm{K}_{\mathrm{d}}$ of 300 Area sediments ( $<2-\mathrm{mm}$ fraction) based on measured surface area and solution composition and $\mathrm{pH}$ (Stoliker et al. 2011). This model reveals that adsorption from river water is three to four times stronger than that from ambient groundwater because of reduced bicarbonate concentration (see Yin et al. 2011). Accordingly, $\mathrm{K}_{\mathrm{d}}$ will be used in discussions below to semiquantitatively characterize the adsorptivity of 300 Area sediments Various publications have explored the merits of the equilibrium $\mathrm{K}_{\mathrm{d}}$, equilibrium surface complexation, and kinetic variants of these models to describe the reactive transport dynamics of the 300 Area uranium plume (Yabusaki et al. 2008; Ma et al. 2010). The general consensus is that the system complexity and its transient chemical composition require a kinetic surface complexation model for adequate description.

A noteworthy, consistent database of laboratory adsorption/desorption measurements has been developed by IFRC researchers who have investigated sediments from the South Process Pond, the North Process Pond, the Process Trenches, and select intervening areas (Qafoku et al. 2005; Bond et al. 2008; Liu et al. 2009; Um et al. 2010; Shang et al. 2011; Stoliker et al. 2011; Murray et al. 2012; Stoliker et al. In Press $\left.{ }^{1}\right)$. Chemical conditions were used for the measurements that simulate ambient 300 Area groundwater conditions (no river water component) in terms of $\mathrm{pH}$, and major cations $\left(\mathrm{Ca}^{2+}, \mathrm{Mg}^{2+}, \mathrm{Na}^{+}\right.$, and $\mathrm{K}^{+}$) and anions $\left(\mathrm{HCO}_{3}{ }^{-}, \mathrm{SO}_{4}{ }^{2+}\right.$, and $\left.\mathrm{NO}_{3}{ }^{-}\right)$. A comprehensive study of contaminated South Process Pond samples from both the PRZ and saturated zones that were washed clean of adsorbed uranium with bicarbonate solution, revealed that Hanford formation sediment (the $<2$-mm fraction) may exhibit a significant $\mathrm{K}_{\mathrm{d}}$ for uranium under ambient groundwater chemical conditions (average $=2.45 \pm 1.56 \mathrm{~L} / \mathrm{kg}$; Murray et al. 2012). However, predicted in situ $\mathrm{K}_{d}$ values are small (generally $\leq 1 \mathrm{~L} / \mathrm{kg}$ ) when the $<2-\mathrm{mm}$ mass fraction as measured in 10-cm-diameter field cores was taken into consideration (Murray et al. 2012). An important unresolved issue is that contaminated sediments from the PRZ generally exhibit substantially higher desorption $\mathrm{K}_{\mathrm{d}}$ values (e.g., three times) in both batch and column experiments than the average noted above.

\footnotetext{
${ }^{1}$ Stoliker DL, C Liu, DB Kent, and JM Zachara. In Press. "Characterizing Particle-Scale Equilibrium Adsorption and Kinetics of Uranium(VI) Desorption from U-Contaminated Sediments." Water Resources Research.
} 


\subsection{Advective Removal of Adsorbed Uranium}

A number of laboratory column experiments have been performed to evaluate how long sediments from the 300 Area PRZ may continue to supply uranium to groundwater. The leaching profile (e.g., dissolved U(VI) versus cumulative water volume) is generally asymptotic, beginning with concentrations that significantly exceed the DWS, and decreasing with volume of groundwater passage to concentrations below the DWS (Figure 5.1). This asymptotic profile has been observed for all 300 Area sediments studied to date (Qafoku et al. 2005; Liu et al. 2009; Yin et al. 2011), indicating that resupply of the plume is expected to follow similar behavior. As is evident for this IFRC site-wide composite $(<8 \mathrm{~mm})$, the passage of approximately 75 pore volumes of fluid is required for released U(VI) concentrations to drop below the DWS. (Recall that approximately one pore volume of groundwater hosting the uranium plume is believed to discharge to Columbia River per year). The release profile is shifted to higher aqueous concentrations with increased amounts of sorbed uranium, or with decreased groundwater flow velocities.

A kinetic surface complexation model has been developed and parameterized that describes this asymptotic response; the results of two different parameterization approaches are shown in Figure 5.1. It is reasonable to assume that PRZ sources in the field will function in this same basic manner, but they will be modified by far more dynamic groundwater flow and geochemical conditions, including adsorption events during river-water intrusion and three-dimensional hydrologic effects. Using this information and kinetic geochemical model to predict plume persistence is difficult, requiring a robust hydrologic simulator that accurately computes groundwater mixing and flux to the river, and includes estimates of the locations and uranium concentrations in PRZ sources. While efforts along these lines are underway, detailed sediment characterization studies at the South Process Pond IFRC site indicate that PRZ sources are heterogeneously distributed, with locations and uranium concentrations that are poorly predictable.

Recent long-term laboratory experiments with 300 Area PRZ sediments suggest that generalizations regarding sorbed U(VI) lability may be incorrect. These generalizations, based on extended bicarbonate extractions of sediment, held that $43 \%$ of the sorbed U(VI) inventory was labile, or available for release to groundwater, while $57 \%$ was nonlabile or recalcitrant. A physicochemical explanation for recalcitrance was never identified. The important implication of this was that only $43 \%$ of the total sorbed U(VI) inventory was considered active in terms of future plume persistence and/or quantity to be remediated. Newer studies including those by Um et al. (2010), Murray et al. (2012), and Shang et al. (In Press $^{1}$ ), indicate that recalcitrant U(VI) can become labile, as sorbed U(VI) is depleted through desorption. Labile U(VI), for example, was exhausted in Figure 5.1 after 130 pore volumes, and total contaminant $\mathrm{U}(\mathrm{VI})$ was used as the total adsorbed $\mathrm{U}(\mathrm{VI})$ concentration for modeling purposes. The transformed, recalcitrant U(VI) did not release U(VI) concentrations in excess of the DWS, but accounting for its formation was essential to describe long-term behavior.

\footnotetext{
${ }^{1}$ Shang JY, C Liu, and JM Zachara. In Press. "The Kinetics of Long-Term Uranyl Desorption in Contaminated Sediments." Environmental Science \& Technology.
} 

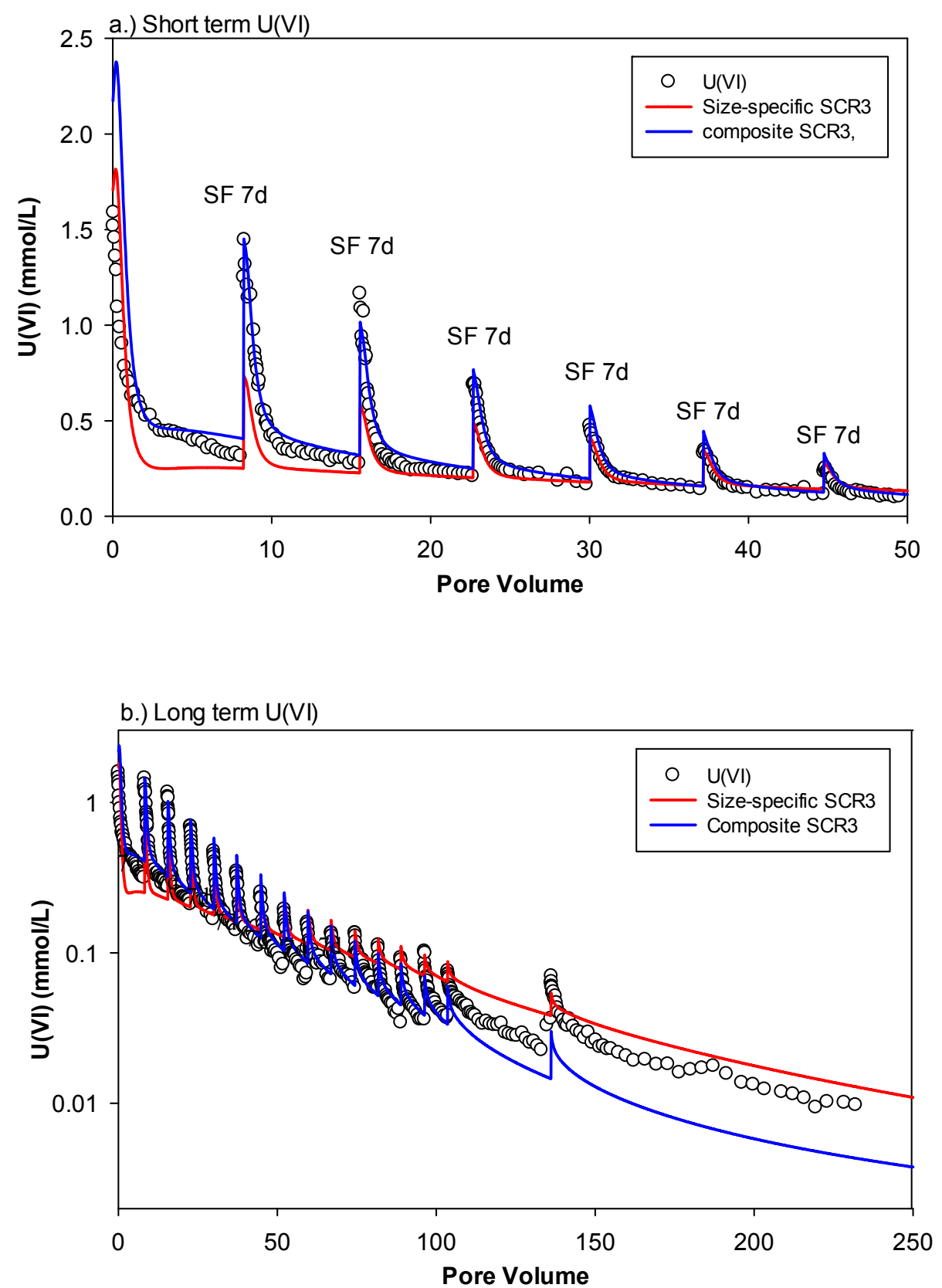

Figure 5.1. Column leaching of contaminant uranium from the $<7-\mathrm{mm}$ size fraction of a composite smear zone sediment from the Hanford IFRC site that was sampled in 2009. Shown are short- and long-term data with the drinking water standard $(0.12 \mu \mathrm{mol} / \mathrm{L})$ as noted. The sediment releases uranium at concentrations above the DWS for approximately 47 pore volumes. Approximately one pore volume of the current 300 Area uranium plume discharges annually to the Columbia River. The figures show a) short-term results and b) long-term results. Two different models have been used to describe the data. The composite SCR3 model is a best fit to the experimental data with one surface complexation reaction. The size-specific SCR3 model is an upscaled, predictive surface complexation model based on the behavior and mass fraction of its various grain size fractions. The latter model is applicable to other 300 Area sediments as well. The long-term study reveals the sediment continues to release uranium after labile uranium has been depleted. Similar behaviors may be expected of all contaminated 300 Area sediments. 


\subsection{Field Measurements of In Situ Uranium Retardation}

Field injection experiments have been performed at the IFRC site to quantify the in situ adsorption/ desorption behavior of U(VI). These experiments have been of three general types: 1) upgradient groundwater with low, background U(VI) to assess in situ desorption rates from aquifer sediments; 2) site groundwater with 10X supplemented U(VI) (from North Process Pond groundwater, $600 \mu \mathrm{g} / \mathrm{L}$ ) to investigate the in situ adsorption extent of uranium solubilized by the spring water level rise under ambient conditions; and 3) filtered river water with 10X supplemented U(VI) to investigate in situ adsorption extent under simulated conditions of river intrusion. All of these injection experiments were performed in the upper high-permeability zone of the plume in the fall or early spring when groundwater flow was to the southeast (towards the Columbia River). Various different injection strategies have been evaluated including fast injections ranging from 12-48 h, to longer ones of 15-21 day duration.

A filtered river water injection experiment with $10 \mathrm{X} \mathrm{U}(\mathrm{VI})$ was also performed in the intermediate low-permeability zone to investigate its mass transfer and adsorption behavior for uranium. In general, it has been observed there is very little retardation in either the upper or lower high-permeability zones $(\mathrm{K} \approx$ $7000 \mathrm{~m} / \mathrm{d}$ ) under ambient conditions, regardless of whether U(VI) is desorbing or adsorbing (e.g., Figure 5.2). The normalized breakthrough curves $\left(\mathrm{C} / \mathrm{C}_{0}\right)$ of both chlorine (injected at $120 \mathrm{mg} / \mathrm{L}$ ) and uranium (injected at $600 \mu \mathrm{g} / \mathrm{L}$ ) are virtually identical (e.g., Figure 5.2b), with all tracer mass accounted for. Only a small hint of uranium retardation (higher $\mathrm{C} / \mathrm{C}_{0}$ values) was evident between 60 and $150 \mathrm{~h}$. Strong aqueous complexation by high bicarbonate prevents measureable adsorption.

A subsequent experiment involving injection to the upper aquifer in this same well (2-34) with the same uranium concentration $(600 \mu \mathrm{g} / \mathrm{L})$ in river water matrix displayed very different behavior (Figure 5.3). There was significant adsorption of uranium over the first 80 hours of the experiment, and tailing (elevated $\mathrm{C} / \mathrm{C}_{0}$ values from $80-300 \mathrm{~h}$ ) as $\mathrm{U}(\mathrm{VI})$ was desorbed by returning groundwater with higher bicarbonate concentration. A retardation factor $(\mathrm{R})$ of 3.5 was estimated where $\mathrm{R}=$ uranium-halflife/tracer-half life. Very high retardation was observed for uranium $(\sim 800 \mu \mathrm{g} / \mathrm{L})$ that was injected into the intermediate low-permeability zone (with $40 \mu \mathrm{g} / \mathrm{L} \mathrm{U}(\mathrm{VI})$, and $\mathrm{K} \approx 2000 \mathrm{~m} / \mathrm{d}$ ) in river water matrix (Figure 5.4). Nonreactive tracers in groundwater $\left(\mathrm{Cl}^{-}\right.$and $\left.\mathrm{SO}_{4}{ }^{2}\right)$ returned to ambient concentrations after $225 \mathrm{~h}$, while dissolved uranium persisted at elevated concentrations $(400-800 \mu \mathrm{g} / \mathrm{L})$ for over 3500 hours during periods of repeated groundwater flow reversals. Concentrations well in excess of the injected concentration ( $>800$ to over $1000 \mu \mathrm{g} / \mathrm{L}$ ) were observed for approximately 1000 hours after the return of ambient groundwater $(225 \mathrm{~h}+)$ as increased bicarbonate induced uranium desorption through enhanced aqueous complexation. A retardation factor (for uranium in ambient groundwater) in the lowpermeability zone in excess of 17 is supported by field data.

The field experiments support a more nuanced conceptual model for uranium adsorptive attenuation in the plume. Uranium-adsorptive attenuation under ambient groundwater conditions is very small to nonexistent (e.g., $\mathrm{R}=1$ and $\mathrm{K}_{\mathrm{d}} \approx 0 \mathrm{~L} / \mathrm{kg}$ ) in coarse textured, Hanford formation sediments with large hydraulic conductivity (e.g., $5000-7000 \mathrm{~m} / \mathrm{d}$ ). The intrusion of river water into these very coarse sediments increases retardation $\left(\mathrm{R} \approx 3.5\right.$ and $\left.\mathrm{K}_{\mathrm{d}} \approx 0.375\right)$ by decreasing aqueous uranium complexation by bicarbonate. (Note that the in situ bulk density and porosity are approximately $2.0 \mathrm{~g} / \mathrm{cm}^{3}$ and 0.3 , respectively). Lower permeability zones $(\mathrm{K} \approx 2000 \mathrm{~m} / \mathrm{d}$; Vermeul et al. 2011) exist within the 300 Area uranium plume that exhibit significant adsorptivity for uranium $\left(\mathrm{R}>17\right.$ and $\left.\mathrm{K}_{\mathrm{d}}>2.4\right)$ in both river water and ambient groundwater matrix. 
a.)

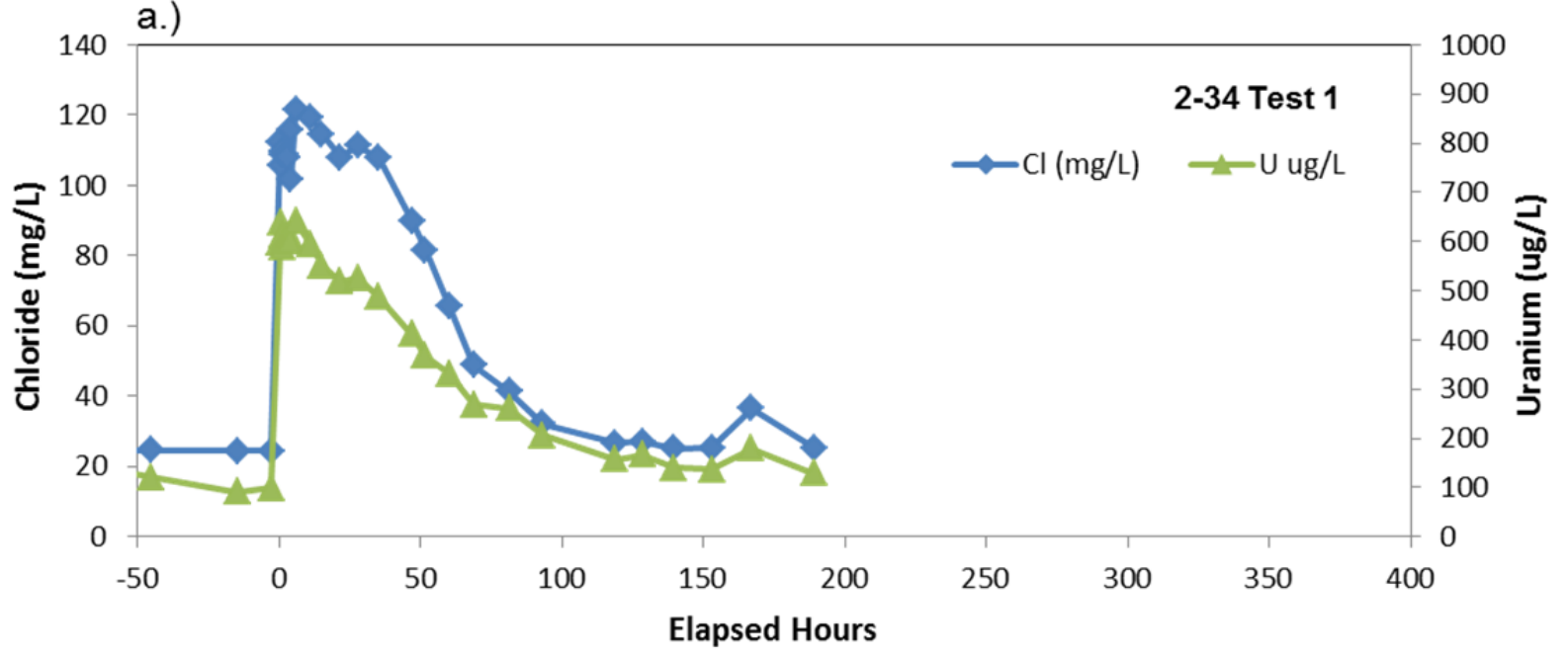

b.)

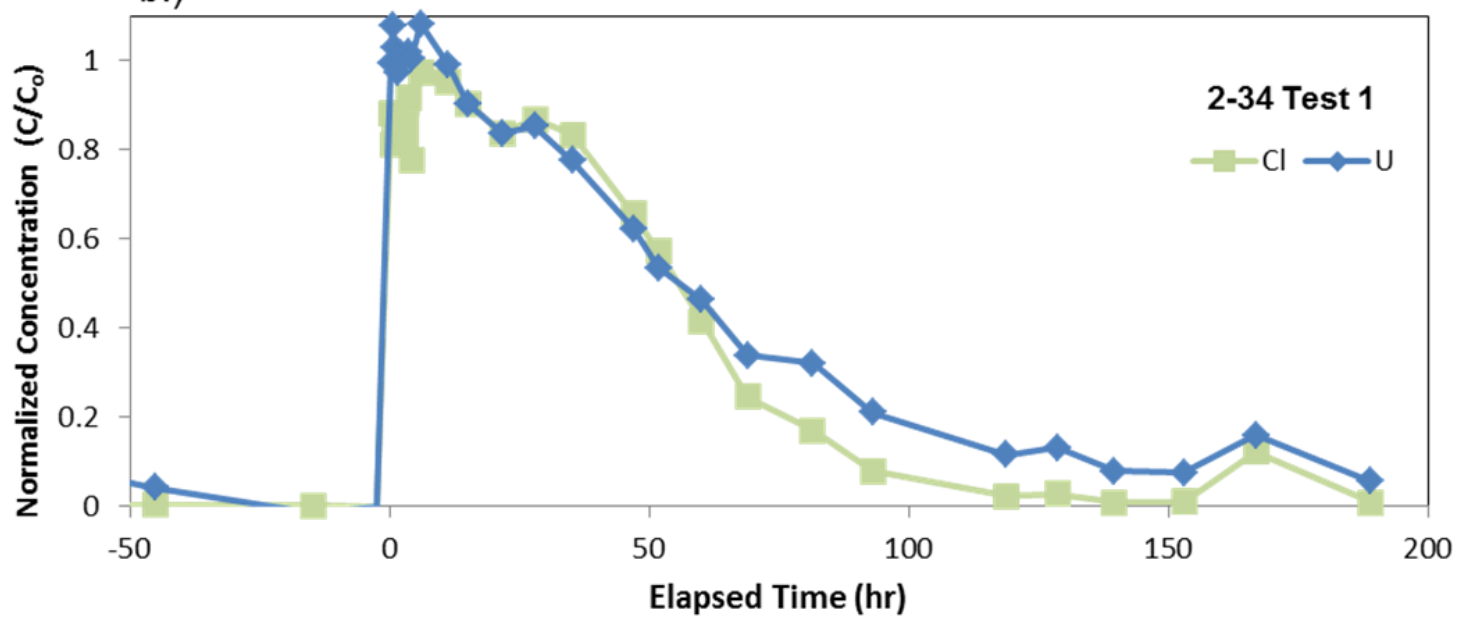

Figure 5.2. Field results for a high uranium injection experiment performed at the Hanford IFRC site in October 2011. High uranium $(600 \mu \mathrm{g} / \mathrm{L})$ was rapidly injected into upper aquifer well 2-34 in a groundwater matrix with $125 \mathrm{mg} / \mathrm{L} \mathrm{Cl}$ - tracer. These concentrations simulate those present in the spring during the high water table event prior to the arrival of intruded Columbia River water. Groundwater flow was primarily toward the river over this time period. The figures show a) measured concentrations and b) normalized concentrations. The nearly identical dissipation behavior of both uranium $(\mathrm{U})$ and chloride $(\mathrm{Cl})$ from the injection well indicates minimal in situ retardation under the injection conditions. 
a.)

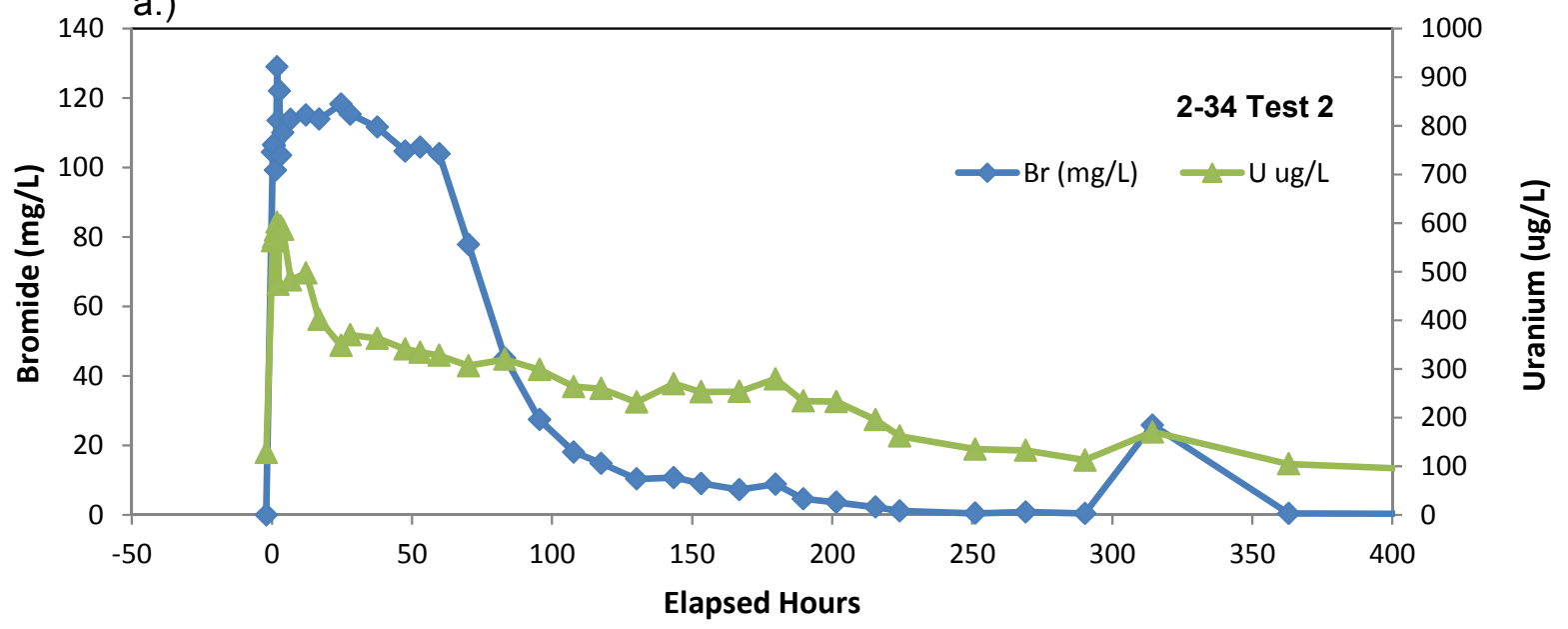

b.)

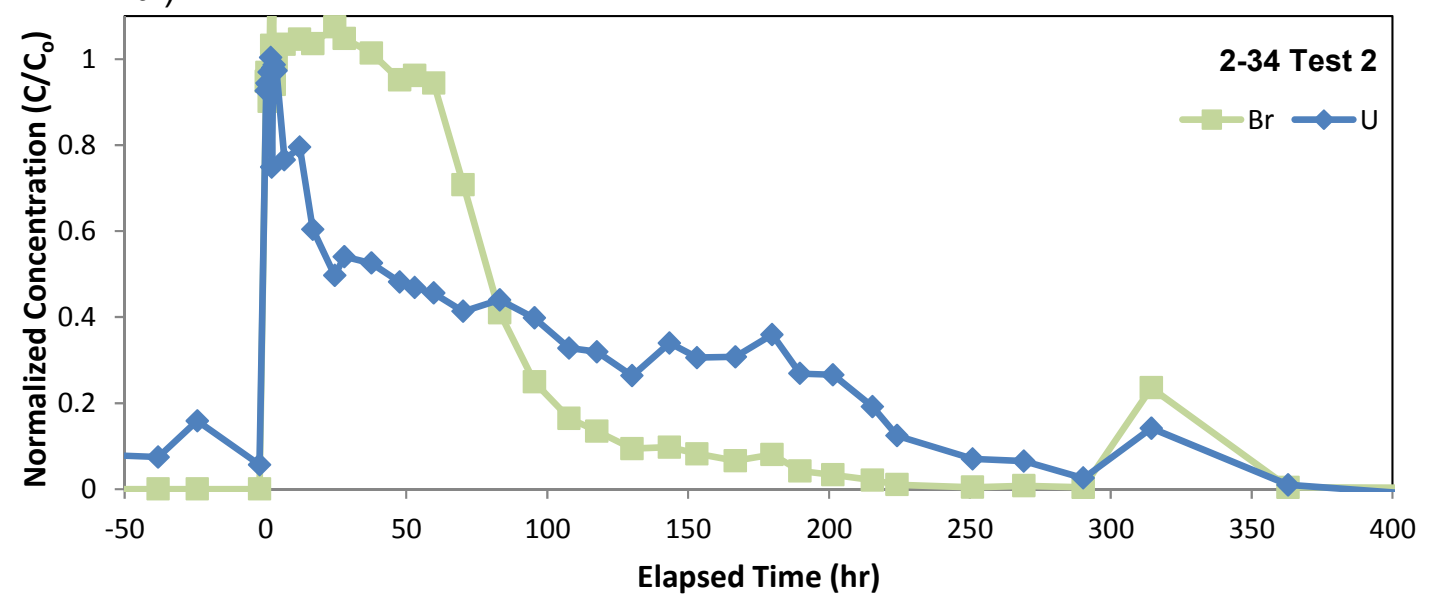

Figure 5.3. Field results for a high uranium injection experiment performed at the Hanford IFRC site in October 2011. High uranium $(600 \mu \mathrm{g} / \mathrm{L})$ was rapidly injected into upper aquifer well 2-34 in a river water matrix with a $125-\mathrm{mg} / \mathrm{L} \mathrm{Br}$ - tracer. These concentrations simulate those present in the spring during the high water table event after the arrival of intruded Columbia River water. Groundwater flow was primarily toward the river over this time period. The figure shows a) measured concentrations and b) normalized concentrations. The very different dissipation behaviors of uranium $(\mathrm{U})$ and chloride $(\mathrm{Cl})$ from the injection well results from the adsorption of significant uranium from the river water matrix, which contains $3 \mathrm{X}$ lower concentrations of $\mathrm{HCO}^{3-}$. Adsorbed uranium is desorbed by returning groundwater as indicated by Br- elution from the well. 


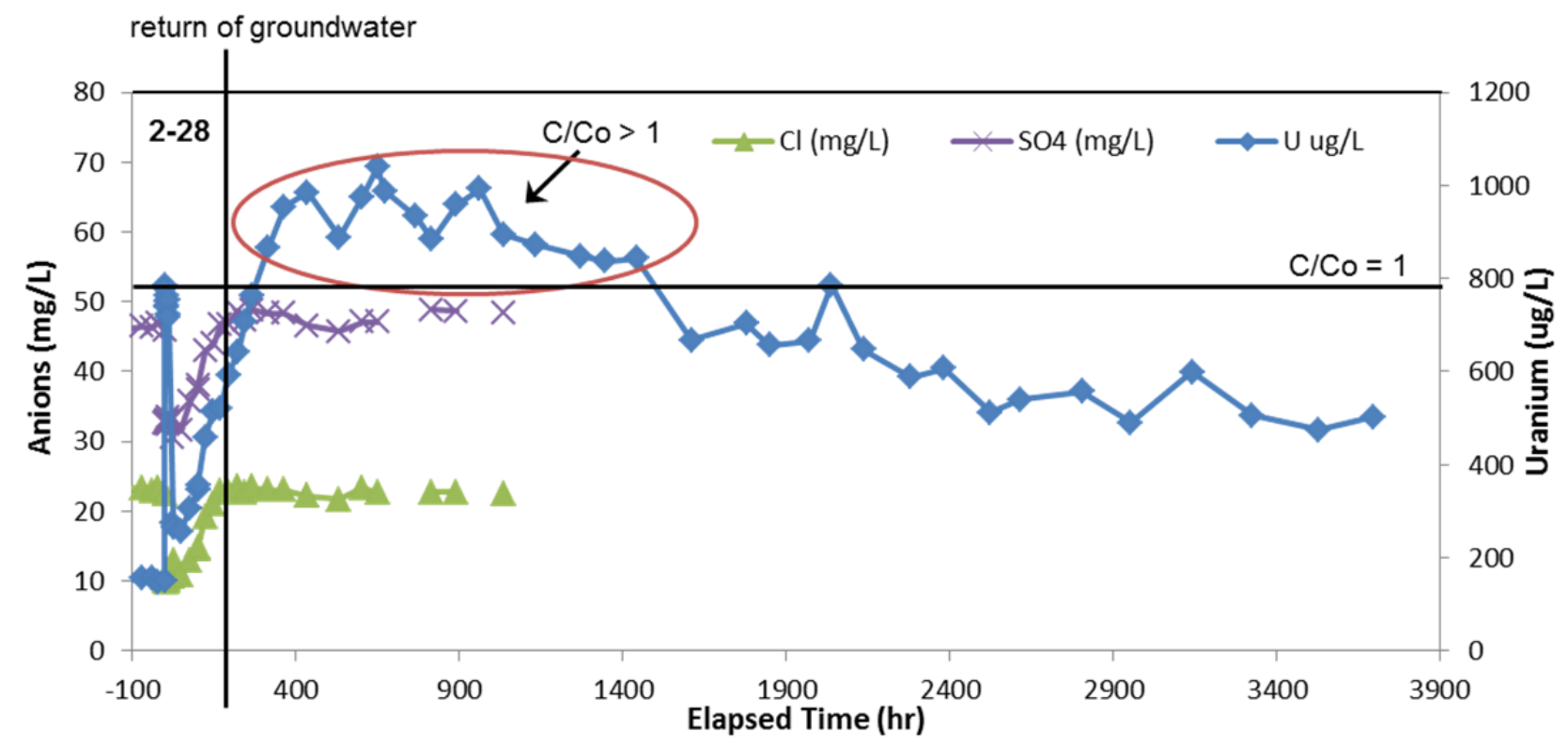

Figure 5.4. Field results for a high uranium injection experiment performed at the Hanford IFRC site in October 2011. High uranium $(800 \mu \mathrm{g} / \mathrm{L})$ was rapidly injected into intermediate depth (low $\mathrm{K} \sim 2000 \mathrm{~m} / \mathrm{d}$ ) aquifer well 2-28 in a river water matrix. At the time of the experiment, the ambient groundwater contained $20 \mathrm{mg} / \mathrm{L} \mathrm{Cl}-, 50 \mathrm{mg} / \mathrm{L} \mathrm{SO}_{4}{ }^{2-}$, and approximately $150 \mu \mathrm{g} / \mathrm{L}$ uranium. Uranium concentrations decreased immediately after injection to approximately $200 \mu \mathrm{g} / \mathrm{L}$ through adsorption. Uranium then increased to well above the injected high level $(\sim 1000 \mu \mathrm{g} / \mathrm{L}, 400-1400 \mathrm{~h})$ through desorption as Cl- and SO4- returned to ambient groundwater levels. High levels of uranium persisted for an additional 2000 hours (1400$3400 \mathrm{~h}$ ) as a result of mass transfer limited desorption.

These zones, texturally characterized as sandy and silty gravels, can retain high dissolved uranium for extended time periods in spite of considerable oscillations in flow directions in nearby higher $\mathrm{K}$ zones. Experience at the IFRC site indicates these low-permeability zones are not evident in drilling logs or through grain-size analysis, but are directly visible to ERT and indirectly to electromagnetic borehole flow surveys in groundwater monitoring wells through their effects on local hydraulic conductivity. The low-permeability zone was a pervasive and relatively contiguous feature throughout the entire $1600-\mathrm{m}^{2}$ footprint of the IFRC site. Beyond the IFRC, there is no information about the presence or frequency of these low-permeability reactive zones.

\subsection{Implications of Geochemical Processes}

An important conclusion of the field injection experiments is the magnitude of observed in situ U(VI) adsorptive retardation is much lower than that estimated by laboratory experiments with field-collected sediments or "intact" field cores (even ones that are $10 \mathrm{~cm}$ in diameter). Three "intact field cores" from the IFRC site, for example, displayed $\mathrm{K}_{\mathrm{d}}$ values of $1.0,1.26$, and $1.99 \mathrm{~L} / \mathrm{kg}$ in whole-core desorption 
experiments with 300 Area groundwater stimulant (Zachara et al. In Press). ${ }^{1}$ The cause for disparity between laboratory and field measurement is likely textural bias and sampling artifacts. The 300 Area sediments are extremely coarse in texture, containing large gravels and river cobble. Core sampling excludes (displaces) the largest river cobbles (e.g., $>10 \mathrm{~cm}$ ), which may compose $25 \%$ or more of the sediment mass. Grain-size analyses of the cored materials will consequently observe finer-textured sediments than actually exist in the field, while geochemical reactivity studies will be biased by a higher concentration of smaller, more reactive particles.

Improved persistence calculations should consider more accurate adsorption-desorption parameters (e.g., surface complexation) for the saturated zone derived from fitting new IFRC field experiment data. While the semiquantitative values of these parameters have been noted in Sections 5.1 and 5.3, inversion and calibration to the full experimental data set of thousands of field measurements has not yet been completed. These parameters would result in more rapid migration velocities for uranium in the saturated zone (with quantifiable uncertainty) because of lower apparent retardation. Beyond this, however, it can be stated the geochemical behavior of uranium in 300 Area sediments is complex, especially in the PRZ. Uranium-release rates from primary repositories in the lower vadose zone are kinetically controlled and not yet predictable. The geochemical behavior of uranium in the PRZ and adjacent lower vadose zone is still insufficiently understood and described in even the most sophisticated of available models to forecast how it will respond to amendments of poly-phosphate for intended in situ stabilization. A key goal is to adequately predict sorbed uranium mobilization in the spring that occurs with the high water table. This test of empirical understanding and models needs to be performed for wells that experience varying degrees of river-water intrusion.

${ }^{1}$ Zachara J, C Liu, M Oostrom, JP McKinley, T Wietsma, and CT Resch. In Press. "Mass Transfer Limited Adsorption and Desorption of U in Intact Sediment Cores Retrieved from a Contaminated Aquifer." Environmental Science \& Technology. 


\subsection{Conceptual Model Refinements}

The objective of this report is to refine and update the conceptual model of the 300 Area uranium plume as described by DOE-RL (2011). The most important model refinements are described in this section. Some refinements are based solely on observations made within the Hanford IFRC site and should be validated at other locations in the 300 Area plume domain.

The 300 Area uranium plume has been well studied. It has an extensive groundwater monitoring network, and a long record of groundwater elevation and concentration measurements. These measurements have been used to infer the impacts of the yearly hydrologic cycle, remediation activities, groundwater hydrogeology, and continued flux to the Columbia River on the character and footprint of the plume. The overall consensus is that the 300 Area subsurface is complex and influenced by spatially variable geologic structures, dynamic surface and hydrogeology on varied time-scales, uncertain and heterogeneous inventory and distribution, effects of historic operational and climatic events on recharge mechanism for the plume, and uranium retardation through highly coupled hydrologic and geochemical processes.

\subsection{Geologic Framework}

The Hanford and Ringold contact is a key geologic feature controlling plume behavior. The topography of the contact has now been extensively mapped through boreholes and geophysical measurements. The topography of the contact is irregular, both under the plume and along the Columbia River shoreline. Topographic low points are erosional channels that are filled with coarse Hanford formation gravels that enable and facilitate groundwater-river water exchange. The variable topography of the contact determines the thickness of the plume; and the locations of active, geologically controlled points of river-water intrusion to the plume and groundwater discharge to the river. The persistence of the plume is strongly influenced by the contact topography through its control on groundwater flux to the river and the spatially variable effects of river-water intrusion on groundwater composition.

One of the most important factors controlling plume persistence is the interaction between highly variable hydrologic conditions and subsurface geology. This combination of hydrogeologic factors creates a situation where groundwater moves rapidly back and forth in response to river stage, but a relatively small mass of uranium discharges to the river. Additional study of the factors controlling uranium concentration trends in wells along the river shoreline (based on more frequent temporal analyses), especially in areas of high Ringold Formation topography and documented groundwater-river water exchange (e.g., uranium flux from the plume), would further improve the conceptual model.

\subsection{Hydrogeology}

Highly variable groundwater flow velocities and trajectories occur in the upper aquifer in response to frequent and seasonal changes in Columbia River stage and its effect on the hydraulic gradient. Groundwater flow velocities vary between 3-25 m/day depending on season and river stage. Flow directions change frequently - sometimes in counter-intuitive directions - and are influenced by the locations of low topography, erosional channels in the Hanford and Ringold contact, which strongly direct 
groundwater flow. Complex flow trajectories complicate the identification of upgradient positions (e.g., wells or uranium sources) and the interpretation of monitoring data.

Multiple facies types, including a finer-grained zone that exhibits lower hydraulic conductivity and significant mass transfer limitations, exist within the aquifer sediments of the groundwater plume. The local hydraulic conductivity field in the IFRC site exhibited extreme variability (Chen et al. 2012), with the most highly transmissive sediments present in the basal domain of the saturated zone. Finer-grained sediments at the IFRC site were present as a contiguous but irregular layer at an intermediate depth in the aquifer. The zone creates complex vertical hydraulic gradients through interaction with pressure fronts generated by river-stage changes that causes wellbore flows in long screened monitoring wells. The lower K sediments contribute to uranium concentration stratification within the groundwater plume (e.g., higher concentrations at shallow depth) by function as a mixing barrier, while in situ experimentation indicates that uranium in this zone is retained for extended periods. The plume-wide distribution of low $\mathrm{K}$ sediments, their connectivity, and their volume fraction are unknown, but will impact uranium retention and plume persistence. Mapping these features using noninvasive geophysical methods would help provide a better description of uranium dissipation within the saturated zone. The lower permeability zone also has implications for vertical flow in wells and interpretation of groundwater monitoring data.

\subsection{Plume Trends and Inventory}

Inspection of the groundwater monitoring data for the uranium plume indicates multiyear trends associated with localized minor and major events of uranium mobilization to groundwater in inland wells, and subsequent migration to the Columbia River. These mobilization events are most commonly associated with the spring high water table; major events are observed when the water table elevation exceeds $107 \mathrm{~m}$ in select inland wells. Mobilization events have also been recognized to follow remediation activities (e.g., 618-5, 618-7 Burial Grounds), perhaps resulting from the effects of water application for dust control (e.g., vadose zone leaching). Groundwater concentrations tend to progressively decrease during intervening periods in a power-law fashion as uncontaminated groundwater mixes with plume waters, and small amounts of contaminated groundwater discharge to the Columbia River. Absent additional inputs, an approximate 6-year period is required for elevated uranium concentrations (e.g., $>100 \mu \mathrm{g} / \mathrm{L}$ ) to dissipate to near the DWS in any given well.

As noted in Section 3.0 of this report, various estimates have been made of the travel times of uranium mobilized at inland wells to the river during spring high water events. Lag times can be observed in wells between the time of high water and the time of peak well-water concentration (e.g., Figure 3.8), possibly indicating travel time from a proximate source. Caution is warranted in estimating travel times because they are highly uncertain due to the localized nature of source terms; frequent directional changes that occur in groundwater flow with resulting complex transport trajectories (Figure 2.11); and the presence of heterogeneously distributed sediment facies and macro-pore domains promoting different retardation factors (e.g., some at $\mathrm{R}=1$ ).

Descriptive parameters for the plume including volume, area, and uranium mass have remained constant for the last 10 years. The plume thus appears relatively stagnant with uranium inputs similar to outputs, and small annual flux to the Columbia River. The plume has not yet entered the asymptotic decay phase, indicating the presence of significant residual uranium in the PRZ. 
The uranium inventory (Peterson et al. 2008b) is uncertain. The magnitude of the inventory, and its spatial and depth distribution, is a key factor controlling plume persistence and influencing the remediation approach. An updated uranium inventory model, building upon that of Peterson et al. (2008), with associated uncertainty would be beneficial for defensible calculation of plume persistence.

A key factor controlling the longevity of the plume is the amount of uranium-contaminated groundwater that exits the plume, viz-a-viz that added to the plume through the spring high water table event. Estimates of uranium mass and volumetric water fluxes to the Columbia River at active groundwater-river exchange points are uncertain and the spatial distribution is not fully characterized. Measurements of parameters to estimate uranium and water flux to the Columbia River could be used to calibrate model projections, and to support flux-balance calculations.

\subsection{Recharge Mechanisms}

Groundwater uranium is resupplied to the plume from heterogeneously distributed inventory hot spots in the lower vadose zone and PRZ during the spring high water table event. No other source of groundwater uranium has yet been identified. Uranium concentrations in some upper aquifer wells increase rapidly, almost instantaneously, as the water table elevation exceeds a nominal value of $106.5 \mathrm{~m}$ in the spring, creating a stratified system with high uranium concentrations at the top of the water table. All IFRC wells screened in the upper aquifer show an increase that varies between wells. The mechanism of this rapid response remains under investigation because it is inconsistent with the kinetic desorption behavior noted in laboratory studies of all 300 Area sediments to date.

Monitoring wells in the upper aquifer show complex, nonuniform behaviors during the high water period, reflecting the collective effects of inventory distribution, multidirectional transport events, and groundwater composition changes resulting from spatially nonuniform groundwater intrusion. Other as yet unidentified factors may also be at play, including meteoric water infiltration and transport through the entire vadose zone.

The effects of natural (meteoric) and anthropogenic (remediation) water infiltration on uranium mobilization from the vadose zone is uncertain; so is the contribution of infiltration to the groundwater plume uranium inventory and persistence. The current conceptual model holds that uranium recharge to the plume occurs by release/solubilization from the lower vadose zone during the period of high water table in the spring. However, concentration trends that are not fully consistent with this model have been observed in the spring at the IFRC site. Meteoric water infiltration is a suspected cause for the disparity. Vadose zone infiltration would access a much larger inventory of sorbed uranium.

The relative significance of dilution/mixing versus geochemical reaction and seasonal geochemical stratification of uranium and solutes $\left(\mathrm{HCO}_{3}{ }^{-}, \mathrm{Ca}^{2+}\right.$, and others) on uranium concentration changes in well-waters during spring river-water intrusion and retreat is uncertain. Recent measurements indicate that significant amounts of uranium enter the top of the plume during the high water table event. However, high-density temporal monitoring of select inland wells that sample the PRZ reveals consistent but complex yearly concentration trends (increasing and decreasing periods) that have not yet been interpreted. A better understanding of these trends through continued monitoring and modeling would enhance the site conceptual model. 
The impacts of the amplitude and duration of the spring snowmelt peak in Columbia River stage on uranium solubilization from the lower vadose zone and local and overall plume inventory are not well characterized. As the presumed source of uranium recharge to the plume, the geochemical behavior of the PRZ needs to be sufficiently described in models to improve forecasting of plume persistence. This description could include time-intense data sets before, during, and after the high water table event at key locations and depths throughout the plume. These data sets over multiple years would be useful for understanding the effects of highly varied hydrologic factors (water table elevation; and gradient, velocity, and direction) that control the kinetic release of uranium from PRZ sediments and proximity effects from nearby wells.

The magnitude of river-water intrusion affects the degree of mixing of spring-mobilized uranium with deeper regions of the plume, and its retardation. River water intrusion, in turn, is controlled by the amplitude and duration of the spring high river-stage event, and the elevation and topography of highly transmissive sediments exposed along the Columbia River shoreline. During years of median spring river stage, river-water intrusion to inland wells (e.g., those more than $50 \mathrm{~m}$ inland) occurs mainly in the upper aquifer. Little of the spring-mobilized uranium becomes mixed with deeper aquifer waters and uranium concentrations in the plume remain stratified for months. In contrast, river-water intrusion occurs over the entire depth interval of the plume during years of high spring water stage, but the arrival of river water at depth is delayed at depth by approximately 1 month. Most important, the deep intrusion of river water appears to facilitate groundwater mixing over the entire depth interval of the plume. These different mixing patterns that are driven by annual differences in river stage have a significant impact on monitoring data collected in the spring, summer, and fall. In some years, the monitoring data will reflect concentrations over the entire plume interval, while in other years they will not.

\subsection{Uranium Retardation}

In situ experimentation has revealed that the adsorptivity of saturated zone sediments within the plume is well below that estimated from laboratory experiments with aquifer cores, and lower than used in recent two-dimensional calculations of plume persistence (DOE-RL 2011). The primary cause for disparity appears to be sampling bias; field cores (even at 10-cm diameter) exclude significant amounts of very coarse-grained materials that dominate the overall mass and volume of the in situ sediment. Consequently, laboratory studies of these materials tend to significantly overestimate in situ retardation. A corollary to this observation is that the range of in situ grain-size distribution is poorly known because of sampling difficulty.

In general, the adsorptivity of saturated zone sediments appears to be dominated by three distinct facies: very coarse-textured Hanford formation gravels (high K) with high connectivity; coarse-textured Hanford formation silty-sandy gravels (low K) with moderate to low connectivity; and infrequent, metersized, silt-textured Ringold Formation rip-up clasts (very low K) with no connectivity. Uranium and tracer transport within the plume is primarily controlled by two coarse-grained facies, whose in situ adsorptivity can be probed by saturated zone injection and free drift experiments of the type performed at the IFRC site. Under ambient groundwater conditions, the adsorptivity of the high $\mathrm{K}$ zone is negligible $\left(\mathrm{K}_{\mathrm{d}} \approx 0\right)$, while that of the low $\mathrm{K}$ zone is measureable $\left(\mathrm{K}_{\mathrm{d}} \approx 0.5-1.0 \mathrm{~L} / \mathrm{kg}\right)$. In the presence of river water where bicarbonate is in lower concentration, these values increase to $0.375 \mathrm{~L} / \mathrm{kg}$ for high $\mathrm{K}$ sediments and 
$>2.4 \mathrm{~L} / \mathrm{kg}$ for low $\mathrm{K}$ Hanford formation sediments. Field experiments also indicate that mass transfer of uranium from the low $\mathrm{K}$ zone to highly transmissive macro-pore regions in high $\mathrm{K}$ sediments is slow, with a half- life exceeding 2000 hours.

Still unresolved is the comparative in situ retardation of uranium in smear zone and saturated zone sediments. This uncertainty remains because it is very difficult to perform quantitative field experiments on in situ retardation in the smear zone because of water-unsaturated conditions during some periods of the year; and highly variable and transient uranium concentrations during other periods when the zone is water saturated. The very slow and sustained release rates of uranium from 300 Area smear zone sediments in the laboratory (e.g., Figure 5.1) have long challenged mechanistic interpretation. Recent field observations of rapid uranium release from smear zone sediments during periods of climbing water table are very difficult to reconcile with these past laboratory experiments. Understanding the causes of these disparities is key to refining the conceptual model, and remains an important scientific challenge. 


\subsection{References}

Arai Y, MA Marcus, N Tamura, JA Davis, and JM Zachara. 2007. "Spectroscopic Evidence for Uranium Bearing Precipitates in Vadose Zone Sediments at the Hanford 300-Area Site." Environmental Science \& Technology 41(13):4633-4639.

Bjornstad BN. 2004. Sampling and Hydrogeology of the Vadose Zone Beneath the 300 Area Process Ponds. PNNL-14834, Pacific Northwest National Laboratory, Richland, Washington.

Bjornstad BN, JA Horner, DC Lanigan, and PD Thorne. 2009. Borehole Completion and Conceptual Hydrogeologic Model of the IFRC Well Field, 300 Area, Hanford Site. PNNL-18340, Pacific Northwest National Laboratory, Richland, Washington.

Bond DL, JA Davis, and JM Zachara. 2007. "Uranium (VI) Release from Contaminated Vadose Zone Sediments: Estimation of Potential Contributions from Dissolution and Desorption." Earth and Environmental Sciences 7(2007):375-416; doi:10.1016/S1571-9197(07)07014-0.

Bond DL, JA Davis, and JM Zachara. 2008. "Uranium (VI) Release from Contaminated Vadose Zone Sediments: Estimation of Potential Contributions from Dissolution and Desorption." In MO Barnett and DB Kent (eds.), Adsorption of Metals by Geomedia II: Variable Mechanisms, and Model Applications. Elsevier, Amsterdam, Netherlands, pp. 375-416.

Comprehensive Environmental Response, Compensation, and Liability Act of 1980. 1980. Public Law 96-510, as amended, 42 USC 9601 et seq.

Chen X, H Murakami, MS Hahn, GE Hammond, ML Rockhold, JM Zachara, and Y Rubin. 2012. "Three-Dimensional Bayesian Geostatistical Aquifer Characterization at the Hanford 300 Area Using Tracer Data." Water Resources Research 48:W06501, doi:10.1029/2011WR010675.

CVP-2003-00021. 2004. Cleanup Verification Package for the 618-5 Burial Ground. Rev. 0, Bechtel Hanford, Inc., Richland, Washington.

CVP-2006-00010. 2006. Cleanup Verification Package for the 618-2 Burial Ground. Rev. 0, Washington Closure Hanford, LLC, Richland, Washington.

CVP-2008-00002. 2010. Cleanup Verification Package for the 618-7 Burial Ground. Rev. 0, U.S. Department of Energy, Richland Operations Office, Richland, Washington.

DOE. 1988. Consultation Draft, Site Characterization Plan, Reference Repository Location, Hanford Site, Washington. DOE-RW-0164, U.S. Department of Energy, Office of Civilian Radioactive Waste Management, Washington, D.C.

DOE-RL. 1992. Expedited Response Action Assessment for 316-5 Process Trenches. DOE/RL-92-32, Revision 0, U.S. Department of Energy, Richland Operations Office, Richland, Washington.

DOE-RL. 1994. Phase I Remedial Investigation Report for the 300-FF-5 Operable Unit.

DOE/RL-93-21, U.S. Department of Energy, Richland Operations Office, Richland, Washington. 
DOE-RL. 2010. Remedial Investigation/Feasibility Study for the 300-FF-1, 300-FF-2, and 300-FF-5 Operable Units. DOE/RL-2010-99, Draft A, U.S. Department of Energy, Richland Operations Office, Richland, Washington.

DOE-RL. 2011. Proposed Plan for the Remediation of 300-FF-1, 300-FF-2, and 300-FF-5 Operable Units, Draft A. DOE-RL-2011-47, U.S. Department of Energy, Richland Operations Office, Richland, Washington.

Fritz BG, NP Kohn, TJ Gilmore, D McFarland, EV Arntzen, RD Mackley, GW Patton, DP Mendoza, and AL Bunn. 2007. Investigation of the Hyporheic Zone at the 300 Area, Hanford Site. PNNL-16805, Pacific Northwest National Laboratory, Richland, Washington.

Fritz BG and EV Arntzen. 2007. "Effect of Rapidly Changing River Stage on Uranium Flux Through the Hyporheic Zone.” Ground Water 45(6):753-760, doi:10.1111/j.1745-6584.2007.00365.x.

Gaylord DR and EP Poeter. 1991. Geology and Hydrology of the 300 Area and Vicinity, Hanford Site, South-Central Washington. WHC-EP-0500, Westinghouse Hanford Company, Richland, Washington.

Gephart RE, RC Arnett, RG Baca, LS Leonhart, and FA Spane. 1979. Hydrologic Studies Within the Columbia Plateau, Washington: An Integration of Current Knowledge. RHO-BWI-ST-5, Rockwell Hanford Operations, Richland, Washington.

Greskowiak J, H Prommer, C Liu, VEA Post, R Ma, C Zheng, and JM Zachara. 2010. "Comparison of Parameter Sensitivities Between a Laboratory and Field Scale Model of Uranium Transport in a DualDomain, Distributed-Rate Reactive System.” Water Resources Research 46:W09509, doi:1029/2009WR008781.

Greskowiak J, MB Hay, H Prommer, CX Liu, VEA Post, R Ma, JA Davis, CM Zheng, and JM Zachara. 2011. "Simulating Adsorption of U(VI) Under Transient Groundwater Flow and Hydrochemistry: Physical Versus Chemical Nonequilibrium Model.” Water Resources Research 47:W08501, doi:10.29/2010WR010118.

Hammond GE and PC Lichtner. 2010. "Field-Scale Model for the Natural Attenuation of Uranium at the Hanford 300 Area Using High-Performance Computing." Water Resources Research 46:W09527, doi:10.1029/2009WR008819.

Hammond GE, PC Lichtner, and ML Rockhold. 2011. "Stochastic Simulation of Uranium Migration at the Hanford 300 Area." Journal of Contaminant Hydrology 120-121:115-128, doi:10.1016/j.jconhyd.2020.04.005.

Haney WA. 1957. Dilution of 300 Area Uranium Wastes Entering the Columbia River. HW-52401, General Electric, Hanford Atomic Products Operation, Richland, Washington.

Langmuir D. 1997. Aqueous Environmental Geochemistry. Prentice Hall, Upper Saddle River, New Jersey.

Lerch JA. 1998. 300 Area Process Trenches Verification Package. BHI-01164, Bechtel Hanford, Inc., Richland, Washington. 
Lindberg JW and FW Bond. 1979. Geohydrology and Groundwater Quality Beneath the 300 Area, Hanford Site, Washington. PNL-2949, Pacific Northwest Laboratory, Richland, Washington.

Lindsey KA. 1995. Miocene- to Pliocene-Aged Suprabasalt Sediments of the Hanford Site, SouthCentral Washington. BHI-00184, Bechtel Hanford, Inc., Richland, Washington.

Lindsey KA and T Tolan. 2009. Geologic Framework of Selected Sedimentary and Columbia River Basalt Group Units in the Columbia Basin Ground Water Management Area of Adams, Franklin, Grant, and Lincoln Counties. Edition 3, GSI Water Solutions, Inc., Kennewick, Washington.

Liu C, JM Zachara, N Qafoku, and Z Wang. 2008. "Scale-Dependent Desorption of Uranium from Contaminated Subsurface Sediments." Water Resources Research 44:W08413, doi:10.1029/2007WR006478.

Liu C, Z Shi, and JM Zachara. 2009. "Kinetics of Uranium(VI) Desorption from Contaminated Sediments: Effects of Geochemical Conditions and Model Evaluation.” Environmental Science \& Technology 43:6560-6566.

Ma R, C Zheng, H Prommer, J Greskowiak, C Liu, J Zachara, and M Rockhold. 2010. "A Field-Scale Reactive Transport Model for U(VI) Migration Influenced by Coupled Multi-Rate Mass Transfer and Surface Complexation Reactions." Water Resources Research 46:W05509, doi:10.1029/2009WR008168.

Ma R, C Zheng, M Tonkin, and JM Zachara. 2011. "Importance of Considering Intraborehole Flow in Solute Transport Modeling Under Highly Dynamic Flow Conditions." Journal of Contaminant Hydrology 123:11-19, doi:10.1016/j.conhyd.2010.12.001.

Ma R, C Zheng, JM Zachara, and M Tonkin. 2012. "Utility of Bromide and Head Tracers for Aquifer Characterization Affected by Highly Transient Flow Conditions." Water Resources Research 48(W08523):1-18, doi:10.1029/2011WR011281.

Murakami H, X Chen, MS Hahn, ML Rockhold, VR Vermeul, JM Zachara, and Y Rubin. 2010. "Bayesian Approach for Three-Dimensional Aquifer Characterization at the Hanford 300 Area." Hydrology and Earth System Sciences 14:1989-2001, doi:10.5194/h3ss-14-1989-2010.

Murray CJ, JM Zachara, JP McKinley, AL Ward, and DA Moore. 2012. "Establishing Geochemical Heterogeneity Model for a Contaminated Vadose-Zone Aquifer System." Journal of Contaminant Hydrology, doi:10.1016/j.jconhyd.2012.02.003.

Myers CW and SM Price (eds.). 1979. Geologic Studies of the Columbia Plateau, A Status Report. RHO-BWI-ST-4, Rockwell Hanford Operations, Richland, Washington.

Peterson RE, BA Williams, and RM Smith. 2008a. Volatile Organic Compound Investigation Results, 300 Area, Hanford Site, Washington. PNNL-17666, Pacific Northwest National Laboratory, Richland, Washington. 
Peterson RE, ML Rockhold, RJ Serne, PD Thorne, and MD Williams. 2008b. Uranium Contamination in the Subsurface Beneath the 300 Area, Hanford Site, Washington. PNNL-17034, Pacific Northwest National Laboratory, Richland, Washington.

Porcello J, T Tolan, and KA Lindsey. 2009. Groundwater Level Declines in the Columbia River Basalt Group and their Relationship to Mechanisms for Groundwater Recharge: A Conceptual Groundwater System Model, Columbia Basin Ground Water Management Area of Adams, Franklin, Grant, and Lincoln Counties. Prepared by GSI Water Solutions, Inc., Kennewick, Washington.

Qafoku N, JM Zachara, C Liu, PL Gassman, O Qafoku, and SC Smith. 2005. "Kinetic Desorption and Sorption of U(VI) During Reactive Transport in a Contaminated Hanford Sediment." Environmental Science and Technology 39(9):3157-3165. doi:10.1021/es048462q

Resource Conservation and Recovery Act of 1976. 1976. Public Law 94-580, as amended, 42 USC 6901 et seq.

Schalla R, RW Wallace, RL Aaberg, SP Airhart, DJ Bates, JVM Carlile, CS Cline, DI Dennison, MD Freshley, PR Heller, EJ Jensen, KB Olsen, RG Parkhurst, JT Rieger, and EJ Westergard. 1988. Interim Characterization Report for the 300 Area Process Trenches. PNL-6716, Pacific Northwest Laboratory, Richland, Washington.

Shang JY, C Liu, ZM Wang, and JM Zachara. 2011. "Effect of Grain Size on Uranium(VI) Surface Complexation Kinetics and Adsorption Additivity." Environmental Science \& Technology 45:6025-6031.

Singer DM, JM Zachara, and GE Brown. 2009. "Uranium Speciation as a Function of Depth in Contaminated Hanford Site Sediments - a Micro-XRF, Micro-XAFS, and Micro-XRD Study." Environmental Science \& Technology 43:630-636.

Slater LD, D Ntarlagiannis, FD Day-Lewis, K Mwakanyamale, RJ VerSteeg, A Ward, C Strickland, T Johnson, and JW Lane, Jr. 2010. "Use of Electrical Imaging and Distributed Temperature Sensing Methods to Characterize Surface Water-Groundwater Exchange Regulating Uranium Transport at the Hanford 300 Area, Washington." Water Resources Research 46:W10533, doi.1029/2011WR009110.

Stoliker DL, DB Kent, and JM Zachara. 2011. "Quantifying Differences in the Impact of Variable Chemistry on Equilibrium Uranium(VI) Adsorption Properties of Aquifer Sediments." Environmental Science \& Technology 45:8733-8740.

Swanson LC. 1992. Phase 1 Hydrogeologic Summary of the 300-FF-5 Operable Unit, 300 Area. WHC-SD-EN-TI-052, Westinghouse Hanford Corporation, Richland, Washington.

Tolan T, KA Lindsey, and J Porcello. 2009. A Summary of Columbia River Basalt Group Physical Geology and its Influence of the Hydrogeology of the Columbia River Basalt Aquifer System: Columbia Basin Ground Water Management Area of Adams, Franklin, Grant, and Lincoln Counties. Prepared by GSI Water Solutions, Inc., Kennewick, Washington. 
Um W, JM Zachara, C Liu, and D Moore. 2010. "Resupply Mechanism to a Contaminated Aquifer: A Laboratory Study of U(VI) Desorption from Capillary Fringe Sediments." Geochimica et Cosmochimica Acta 74(18):5155-5170, doi:10.1016/j.gca.2020.02.001.

Vermeul VR, BN Bjornstad, BG Fritz, JS Fruchter, RD Mackley, DR Newcomer, DP Mendoza, ML Rockhold, DM Wellman, and MD Williams. 2009. 300 Area Uranium Stabilization Through Polyphosphate Injection: Final Report. PNNL-18529, Pacific Northwest National Laboratory, Richland, Washington.

Vermeul VR, JP McKinley, DR Newcomer, RD Mackley, and JM Zachara. 2011. "River-Induced Flow Dynamics in Long-Screen Wells and Impact on Aqueous Samples." Groundwater 49:515-524.

Waitt RB, RP Denlinger, and JE O'Connor. 2009. "Many monstrous Missoula floods down Channeled Scabland and Columbia Valley." In JE O'Connor, R Dorsey, and I Madin (eds.), Volcanoes to Vineyards: Geologic Field Trips through the Dynamic Landscape of the Pacific Northwest. ISBN: 978-0-8137-0015-1, GSA Field Guide 15, pp. 775-844, doi:10.1130/2009.fld015(33).

Wang Z, JM Zachara, JF Boily, D Moore, Y Xia, and K Draper. 2011. "Unraveling U(VI) Surface Speciation at Low Concentration by CLIFS Spectroscopy: Application to Contaminated Aquifer Sediments." Geochimica et Cosmochimica Acta 75:2965-2979.

Williams BA, CF Brown, W Um, MJ Nimmons, RE Peterson, BN Bjornstad, DC Lanigan, RJ Serne, FA Spane, and ML Rockhold. 2007. Limited Field Investigation Report for Uranium Contamination in the 300 Area, 300-FF-5 Operable Unit, Hanford Site, Washington. PNNL-16435, Pacific Northwest National Laboratory, Richland, Washington.

Williams MD, ML Rockhold, PD Thorne, and Y Chen. 2008. Three-Dimensional Groundwater Models of the 300 Area at the Hanford Site, Washington State. PNNL-17708, Pacific Northwest National Laboratory, Richland, Washington.

Yabusaki SB, Y Fang, and SR Waichler. 2008. "Building Conceptual Models of Field-Scale Reactive Transport in a Dynamic Vadose Zone-Aquifer-River System." Water Resources Research 44:W12403, doi:10.1029/2007WR006617.

Yin J, R Haggerty, DL Stoliker, DB Kent, JD Istok, J Greskowiak, and JM Zachara. 2011. "Transient Groundwater Chemistry Near a River: Effects on U(VI) Transport in Laboratory Column Experiments." Water Resources Research 47:W04502, doi:10.1029/2010WR009369.

Zachara JM. 2009. Multi-Scale Mass Transfer Processes Controlling Natural Attenuation and Engineered Remediation: An IFRC Focused on Hanford's 300 Area Uranium Plume, January 2008 to January 2009. PNNL-SA-64785, Pacific Northwest National Laboratory, Richland, Washington. 
Zachara JM, JA Davis, C Liu, JP McKinley, N Qafoku, DM Wellman, and SB Yabusaki. 2005. Uranium Geochemistry in Vadose Zone and Aquifer Sediments from the 300 Area Uranium Plume. PNNL-15121, Pacific Northwest National Laboratory, Richland, Washington.

Zachara J, C Brown, J Christensen, JA Davis, E Dresel, C Liu, S Kelly, J McKinley, J Serne, and W Um. 2007. A Site-Wide Perspective on Uranium Geochemistry at the Hanford Site. PNNL-17031, Pacific Northwest National Laboratory, Richland, Washington. 


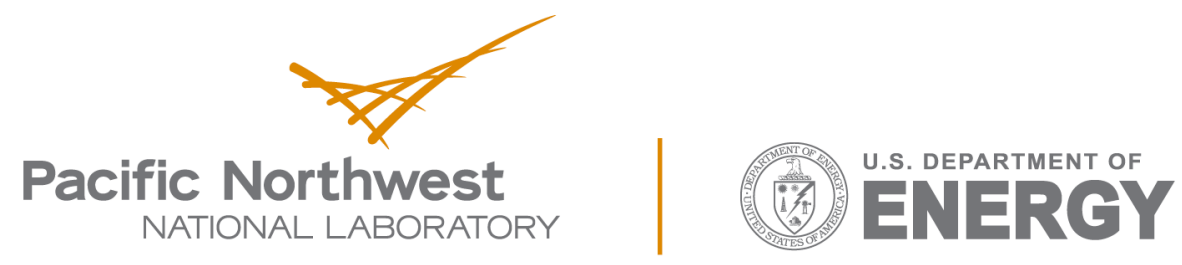

Proudly Operated by Battelle Since 1965

902 Battelle Boulevard

P.O. Box 999

Richland, WA 99352

1-888-375-PNNL (7665)

www.pnnl.gov 